CYNTHIA PEREIRA DA COSTA E SILVA

Imunidade inata no sangue e secreção mamária de vacas Holandesas no período periparto 


\title{
Imunidade inata no sangue e secreção mamária de vacas Holandesas no período periparto
}

Dissertação apresentada ao Programa de Pós-Graduação em Clínica Veterinária da Faculdade de Medicina Veterinária e Zootecnia da Universidade de São Paulo para obtenção do título de Mestre em Ciências

\section{Departamento:}

Clínica Médica

\author{
Área de concentração: \\ Clínica Veterinária \\ Orientador: \\ Prof $^{a}$. Dr ${ }^{a}$. Viviani Gomes
}


Autorizo a reprodução parcial ou total desta obra, para fins acadêmicos, desde que citada a fonte.

DADOS INTERNACIONAIS DE CATALOGAÇÃO-NA-PUBLICAÇÃO

(Biblioteca Virginie Buff D’Ápice da Faculdade de Medicina Veterinária e Zootecnia da Universidade de São Paulo)

\footnotetext{
T.2978 Silva, Cynthia Pereira da Costa e

FMVZ Imunidade inata no sangue e secreção mamária de vacas Holandesas no periodo periparto / Cynthia Pereira da Costa e Silva. -- 2014.

142 f. f.: il.

Dissertação (Mestrado) - Universidade de São Paulo. Faculdade de Medicina Veterinária e Zootecnia Departamento Clínica Médica, São Paulo, 2014

Programa de Pós-Graduação: Clínica Veterinária.

Área de concentração: Clínica Veterinária.

Orientador: Prof ${ }^{a}$. Dr ${ }^{\mathrm{a}}$. Viviani Gomes.

1. Colostro. 2. Inflamação. 3. Mastite. 4. Periparto. 5. Periodo de transição. 6. Vacas. I. Título.
} 


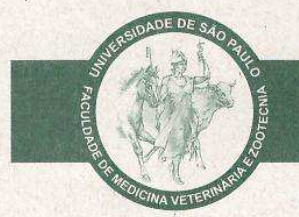

UNIVERSIDADE DE SÃO PAULO

FACULDADE DE MEDICINA VETERINÁRIA E ZOOTECNIA

Comissão de Ética no uso de animais

\section{CERTIFICADO}

Certificamos que o Projeto intitulado "Imunidade inata no sangue e secreção mamária de vacas holandesas no período periparto", protocolado sob o $\mathrm{n}^{\circ}$ 2766/2012, utilizando 10 (dez) bovinos, sob a responsabilidade da Profa. Dra. Viviani Gomes, está de acordo com os princípios éticos de experimentação animal da "Comissão de Ética no uso de animais" da Faculdade de Medicina Veterinária e Zootecnia da Universidade de São Paulo e foi aprovado em reunião de 19/9/2012.

We certify that the Research "Innate immunity in blood and mammary secretion of Holstein cows in the peripartum period", protocol number 2766/2012, utilizing 10 (ten) bovine, under the responsibility Profa. Dra.Viviani Gomes, agree with Ethical Principles in Animal Research adopted by "Ethic Committee in the use of animals" of the School of Veterinary Medicine and Animal Science of University of São Paulo and was approved in the meeting of day $9 / 19 / 2012$.

São Paulo, 21 de maio de 2013.

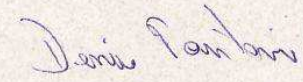

Denise Tabacchi Fantoni

Presidente 
Nome: SILVA, Cynthia Pereira da Costa e

Título: Imunidade inata no sangue e secreção mamária de vacas Holandesas no período periparto.

Dissertação apresentada ao Programa de Pós-Graduação em Clínica Veterinária da Faculdade de Medicina Veterinária e Zootecnia da Universidade de São Paulo para obtenção do título de Mestre em Ciências

Data:

Banca Examinadora

Prof. Dr.:

Instituição: Julgamento:

Prof. Dr.:

Instituição: Julgamento:

Prof. Dr.:

Instituição: Julgamento: 


\section{DEDICATÓRIAS}

Dedico este trabalho a Deus, pois foi Ele quem guiou meus passos pra chegar até aqui e me deu forças pra batalhar e vencer todos os dias.

Aos meus pais que são o meu porto seguro, meu exemplo de luta, dedicação e amor.

Às minhas irmãs pela grande amizade, companheirismo, exemplo de vida, e por todo o amor e orações.

Aos meus sobrinhos que são a minha alegria, minha vontade de ser uma pessoa melhor e conquistar as coisas.

Ao maior presente que recebi no mestrado, o meu namorado pela força, dedicação, amor e amizade.

A minha orientadora, que com tanta paixão se dedica à pesquisa. 


\section{AGRADECIMENTOS}

À Deus pela força nos difíceis momentos que enfrentei, pela paz sobrenatural que em tantas vezes invadiu minha alma, e pelo amor que Ele demonstra todos os dias a partir do momento que me levanto!

À minha orientadora, Prof ${ }^{a}$. Dra . Viviani Gomes pelo estímulo e encorajamento frente a cada novo desafio. Sua dedicação e ensinos me permitiram continuar, alcançar uma grande meta, e acima de tudo, amadurecer. Serei sempre grata e levarei todos os ensinamentos comigo. Ao alcançar outras metas, continuarei a ser grata, pois toda boa casa construída necessitou de um bom alicerce.

Aos colegas de equipe: Camila pelas risadas e descontração; Vinicius pelo convívio, bons momentos, dedicação e ajuda; Sylvia pela amizade e ajuda no momento mais difícil do mestrado, sempre com muito amor e carinho; Bruno pela ajuda e bons momentos; Juliana pela dedicação incansável, trabalho duro, sorriso no rosto e músicas que alegravam as nossas noites.

Aos amigos do Programa de Pós-Graduação pela amizade, ajuda e churrascos. $O$ meu tempo com vocês foi muito especial, e vou levar e guardar o carinho por vocês sempre. Sucesso pra todos nós!

À minha família: Aos meus pais pelo total apoio, pelos grandes conselhos, pelas incansáveis orações e preocupações com a minha vida. Amo vocês, e agradeço por serem meus. Vocês são inigualáveis e tem todo meu respeito, admiração e amor. Às minhas lindas irmãs pelo companheirismo, conselhos e amizade, a mais linda e sincera que eu tenho! Vocês são meu exemplo! Amo vocês com o maior amor do mundo! Aos meus cunhados por cuidarem das minhas meninas, e por terem participado da confecção dos meus maiores tesouros! Aos meus sobrinhos por simplesmente fazerem minha vida mais bonita, agitada e alegre. $O$ amor que tenho por vocês é o maior do mundo. Tenho muito orgulho de vocês. Vocês são lindos, educados, inteligentes, criativos, sinceros, carinhosos, enfim, vocês são minha maior alegria. Família querida, vocês são a melhor coisa que eu tenho. São especiais e 
muito amados. Com vocês as dificuldades se tornam pequenas e tudo volta a fazer sentido e valer a pena. Não existe família melhor. Amo vocês!

Ao meu querido namorado, meu companheiro de tantos momentos. Obrigada por tornar essa caminhada mais leve e mais gostosa. O seu apoio, grande ajuda e dedicação foram muito importantes para a conclusão desta etapa. O seu amor tão sincero me encanta e faz minha vida mais doce e bonita. Você é o amor da minha vida. Te amo pra sempre e sou muito feliz ao seu lado!

Aos meus amigos que mesmo com a distância e falta de tempo, nunca desistiram de mim, pelo contrário, torceram e compreenderam esses momentos! As amizades fazem a vida valer a pena. Que bom ter vocês!

Ao ilustre diretor da FMVZ/USP Prof. Dr. Enrico Lippi Ortolani e aos admirados professores do Departamento de Clínica Médica: Prof. Dr. Archivaldo Reche Junior, Prof. Dr. Carlos Eduardo Larsson, Prof ${ }^{a}$ Dr ${ }^{a}$ Lílian Gregory, Prof ${ }^{a}$ Dr ${ }^{\underline{a}}$ Marcia Mery Kogika, Prof ${ }^{a}{ }^{2} r^{a}$ Maria Cláudia Araripe Sucupira, Prof ${ }^{a}$ Dr ${ }^{a}$ Maria Helena Matiko Akao Larsson, Prof ${ }^{a}$ Dr $^{a}$ Mitika Hagiwara, Prof ${ }^{a}$ Dr $^{a}$ Raquel Yvona Arantes Baccarin, Prof $^{a}$ Dr $^{\text {a }}$ Silvia Regina Ricci, e Prof. Dr. Wilson Roberto Fernandes.

Ao Prof. Dr. David John Hurley por nos ensinar suas técnicas que foram construídas durante um longo tempo. Nunca me esquecerei de seu ensinamento. Obrigada por receber a família Gomes et al. em sua universidade e sua casa. Pudemos fazer grandes amigos e conhecer pessoas admiráveis.

À Prof ${ }^{a}$ Dr $^{a}$ Cristina de Oliveira Massoco Salles Gomes pelo conhecimento transmitido e desmistificação do citômetro e FlowJo. Sua ajuda foi essencial.

À Nicolle Gilda Teixeira de Queiroz Hazarbassanov e aos funcionários do laboratório por todo o tempo dedicado e grande ajuda na realização de uma etapa essencial para a realização desta pesquisa. Vocês foram muito gentis e sempre prontos em todos os momentos que precisei. 
À Prof ${ }^{a}$ Dr ${ }^{a}$ Alice Maria Melville Paiva Della Libera pelo auxílio, conhecimento e dicas. E por formar uma linda e prestativa equipe, principalmente durante a madrugada que precisava de alguma coisa, né Camila? Ou uma bactéria aqui ou ali pra testar e ficar pronta pro meu trabalho né meninas? Muito obrigada mesmo, serei sempre grata.

À Cláudia Regina Stricagnolo pelo apoio, paciência e ajuda nos muitos momento necessários. Sempre me lembrarei de seu jeito único de brigar comigo. Entende que foram necessários e serei sempre grata pela ajuda

À Samantha Ive Miyashiro pela ajuda com o ex-temido citômetro e pilotos do meu projeto. Muito obrigada pela pronta ajuda.

À Edna Santana pela ajuda com os materiais e pelo vasto respertório musical!

À toda equipe dos Laboratórios da FMVZ/USP, Clara Mori, Maria Helena da Silva Pelissari, Marly Elizabethe Ferreira.

Ao Instituto de Zootecnia (APTA - Gado de Leite) pela permissão concedida para utilização dos animais e dependências do local. Juliana Rodrigues Pozzi Arcaro e Cláudia Rodrigues Pozzi obrigada pela confiança; Mariana Miranda pela ajuda; aos funcionários do IZ, Ana, Donizete, Sr. Valter, Gillberto e Izildinha pela amizade construída e por toda a ajuda e paciência; aos amigos que pude fazer no tempo em que estive lá, Gianni, Joana, Lucas, Mandí, Maurício, Gisele e Bianca, a amizade e as lembranças dos bons momentos serão eternas.

Ao Mailson pela ajuda essencial na fazenda. Obrigada por todo apoio, esforço e por cuidar tão bem das "nossas" vacas.

A Camila Martins pela ajuda nas coletas e auxílio com as "meninas". 
Aos residentes do CBPR da época de 2010, 2011, 2012, 2013 e 2014. Durante esse tempo pude conhecer muita gente e fazer muito amigos. Vocês são especiais. Muito sucesso!

À FAPESP pela concessão da bolsa de mestrado. 


\section{EPÍGRAFE}

Ainda que eu falasse a língua dos homens e dos anjos, e não tivesse amor, seria como o metal que soa ou como o sino que tine.

$E$, ainda que tivesse $o$ dom de profecia e conhecesse todos os mistérios e toda a ciência, e ainda que tivesse toda a fé de maneira tal que transportasse os montes, e não tivesse amor, nada seria.

I Coríntios 13:1-2 


\section{RESUMO}

SILVA, C. P. C. e. Imunidade inata no sangue e secreção mamária de vacas Holandesas no período periparto. [Innate immunity in blood and mammary secretion of Holstein cows in the peripartum period]. 2014. $142 \mathrm{f}$. Dissertação (Mestrado em Ciências) - Faculdade de Medicina Veterinária e Zootecnia, Universidade de São Paulo, São Paulo, 2014.

O periparto é um período crítico no qual as adaptações fisiológicas e imunológicas ocorridas podem ser responsáveis pela susceptibilidade às infecções intramamárias, durante o processo de colostrogênese. Desta forma, o estudo da imunidade inata e sua resposta frente aos patógenos bacterianos são fundamentais para entendimento, diagnóstico e adoção de medidas profiláticas para a mastite bovina. Portanto, o objetivo deste trabalho foi avaliar a imunidade inata no sangue e secreção mamária de vacas da raça Holandesa no período periparto e sua resposta frente à exposição natural aos patógenos bacterianos durante a colostrogênese. Para tanto, foram avaliadas amostras de sangue $(n=91)$ e secreção mamária $(n=208)$ de treze fêmeas bovinas de $2^{\circ}$ a $4^{\circ}$ parição. As vacas foram avaliadas semanalmente nas três semanas que antecedem e sucedem a parição prevista. A avaliação da resposta imune inata e detecção do processo inflamatório da glândula mamária (GM) foram realizadas por meio do exame específico da GM, exame bacteriológico, contagem de células somáticas da secreção mamária e provas imunológicas, tais como: viabilidade das células do colostro/leite; dosagem da citocina pró-inflamatória interferon-gama (IFN-Y), imunofenotipagem e avaliação funcional de leucócitos polimorfonucleares $\mathrm{CH}_{138^{+}}$. Com base nos resultados obtidos, pode concluir-se que: a) A parição representou o momento com maior taxa de infecção mamária, no entanto, as alterações mamárias decorrentes do processo de colostrogênese limitaram o uso de exame específico do aparelho mamário para detecção da mastite clínica; b) A função dos neutrófilos sanguíneos nos momentos M-2 e M-1 apresentou-se diminuída, este fenômeno pode ter contribuído para maiores taxas de infecção mamária e exacerbação da função dos neutrófilos sanguíneos no momento da parição; c) A resposta nos neutrófilos sanguíneos não foi exclusiva da GM e apresentaram-se intensificadas nos momentos com alta frequência de inflamações uterinas no pós-parto; d) A GM apresenta-se altamente 
susceptível às infecções bacterianas no pós-parto imediato, decorrente da baixa viabilidade celular, reduzida proporção e atividade funcional dos neutrófilos $\mathrm{CH} 138^{+}$ residentes. A adaptação ao pós-parto e aumento da atividade funcional dos neutrófilos da secreção mamária foi observada nas semanas subsequentes ao parto, resultando em diminuição da taxa de infecção bacteriana.

Palavras-chave: Colostro. Inflamação. Mastite. Periparto. Período de transição. Vacas. 


\begin{abstract}
SILVA, C. P. C. e. Innate immunity in blood and mammary secretion of Holstein cows in the peripartum period. [Imunidade inata no sangue e secreção mamária de vacas Holandesas no período periparto]. 2014. 142 f. Dissertação (Mestrado em Ciências) - Faculdade de Medicina Veterinária e Zootecnia, Universidade de São Paulo, São Paulo, 2014.
\end{abstract}

Peripartum is a critical period in which physiological and immunological adaptations occurred may be responsible for susceptibility to mammary infections during colostrogenesis. Thus, the study of innate immunity and its response against bacterial pathogens are crucial for understanding, diagnosis and adoption of prophylactic measures for bovine mastitis. Therefore, the aim of this study was to evaluate the innate immunity in blood and mammary secretion of lactating Holstein cows in the peripartum period and its response due to natural exposure to bacterial pathogens during colostrogenesis. For this, blood $(n=91)$ and mammary secretion ( $n=208$ ) samples of thirteen dry cows from $2^{\circ}$ to $4^{\circ}$ calving were evaluated. Cows were evaluated weekly in the three weeks preceding and following the predicted birth. The evaluation of the innate immune response and detection of inflammation of the mammary gland (MG) were performed using specific examination of $M G$, bacteriological, somatic cell count (SCC) of mammary secretions and immunological tests, such as: cell viability of colostrum / milk; dosage of pro-inflammatory cytokine interferon -gamma (IFN - Y), immunophenotyping and functional assessment of polymorphonuclear leukocytes $\mathrm{CH}_{138}{ }^{+}$. Based on the results obtained, it can be concluded that : a) The calving represented the moment with the highest rate of mammary infection, however, the mammary changes resulting from the colostrogenesis limited the use of specific examination of the mammary system for clinic mastitis detection; b) The function of blood neutrophils in the moments $\mathrm{M}-2$ and $\mathrm{M}$ - 1 showed reduced, this phenomenon may have contributed to higher rates of mammary infection and exacerbation the blood neutrophils function of at parturition moment ; c) The response in blood neutrophils was not exclusive to MG and presented intensification in moments with high frequency of uterine inflammation in postpartum; d) The MG has to be highly susceptible to bacterial infections in the immediate postpartum period, due to low cellular viability ratio and reduced functional 
activity of residents $\mathrm{CH}_{138^{+}}$neutrophils . The adaptation to postpartum and increased functional activity of neutrophils in mammary secretion was observed in the following partum weeks, resulting in decreased rate of bacterial infection.

Keywords : Colostrum. Inflammation. Mastitis. Peripartum. Transition period. Cows. 


\section{LISTA DE TABELAS}

Tabela 1 - Frequências (\%) dos quesitos obtidos pela inspeção e palpação dos quartos mamários de vacas Holandesas no

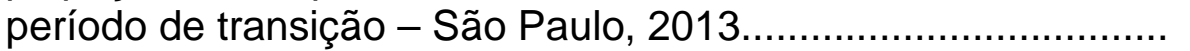

Tabela 2 - Diferenças estatísticas obtidas entre os momentos segundo 0 teste de Teste de McNemar.

Tabela 3 - Proporção (\%) de leucócitos PMN e neutrófilos $\mathrm{CH}_{138^{+}}$ presentes no sangue de vacas Holandesas durante o período de transição - São Paulo, 2013.

Tabela 4 - Valor absoluto (VA) de leucócitos PMN e neutrófilos $\mathrm{CH}_{138^{+}}$ presentes no sangue de vacas Holandesas durante o período de transição - São Paulo, 2013.

Tabela 5 - Proporção (\%) e intensidade da fagocitose (Média Geométrica) de Staphylococcus aureus pelos neutrófilos $\mathrm{CH}_{138^{+}}$do sangue de vacas Holandesas no período de transição - São Paulo, 2013

Tabela 6 - Proporção (\%) e intensidade da fagocitose (Média Geométrica) de Escherichia coli pelos neutrófilos $\mathrm{CH} 138^{+}$do sangue de vacas Holandesas no período de transição - São Paulo, 2013..

Tabela 7 - Valores relativos (\%) e média geométrica da produção basal de peróxido de hidrogênio pelos neutrófilos $\mathrm{CH}_{138^{+}}$ sanguíneos de vacas Holandesas no período de transição São Paulo, 2013.

Tabela 8 - Produção de peróxido de hidrogênio pelos neutrófilos sanguíneos $\mathrm{CH} 138^{+}$estimulados com Staphylococcus aureus em vacas Holandesas no período de transição - São Paulo, 2013.

Tabela 9 - Produção de peróxido de hidrogênio pelos neutrófilos sanguíneos $\mathrm{CH}_{138^{+}}$estimulados com Escherichia coli em vacas Holandesas no período de transição - São Paulo, 2013..

Tabela 10 - Contagem de células somáticas (CCS) na secreção mamária de vacas Holandesas no pós-parto - São Paulo, 2013.

Tabela 11 - Contagem de células somáticas (CCS) na secreção mamária em vacas Holandesas no pós-parto imediato, de acordo com o status infeccioso da glândula mamária, São Paulo, 2013

Tabela 12 - Proporção (\%) de células viáveis obtidas a partir do colostro e leite de vacas Holandesas no pós-parto - São Paulo, 2013........

Tabela 13 - Concentração de células totais viáveis observadas no leite de vacas Holandesas no pós-parto - São Paulo, 2013. 
Tabela 14 - Número de amostras (N.) adequadas e inadequadas para a inclusão nos ensaios de proporção e função de neutrófilos em vacas Holandesas no pós-parto - São Paulo, 2013.................. 95

Tabela 15 - Proporção (\%) de neutrófilos $\mathrm{CH}_{138^{+}}$presentes no leite de vacas Holandesas no pós-parto - São Paulo, 2013....................

Tabela 16 - Proporção (\%) e intensidade da fagocitose de Staphylococcus aureus (Média Geométrica) pelos neutrófilos $\mathrm{CH}_{138^{+}}$do colostro e leite de vacas Holandesas no pós-parto - São Paulo, 2013

Tabela 17 - Proporção (\%) e intensidade da fagocitose (Média Geométrica) de Escherichia coli pelos neutrófilos $\mathrm{CH}_{138^{+}}$do colostro e leite de vacas Holandesas no período de transição - São Paulo, 2013.

Tabela 18 - Produção basal de peróxido de hidrogênio pelos neutrófilos $\mathrm{CH} 138^{+}$do colostro e leite de vacas Holandesas no período de transição - São Paulo, 2013.

Tabela 19 - Produção de peróxido de hidrogênio, com estímulo da Staphylococcus aureus, pelos neutrófilos $\mathrm{CH}_{138^{+}}$do colostro e leite de vacas Holandesas no pós-parto - São Paulo, 2013.......

Tabela 20 - Produção de peróxido de hidrogênio, com estímulo da Escherichia coli, pelos neutrófilos $\mathrm{CH} 138^{+}$do colostro e leite de vacas Holandesas no pós-parto - São Paulo, 2013. 


\section{LISTA DE FIGURAS}

Figura 1 - Piquetes onde as vacas foram mantidas no período pré $(A / B)$ e pós-parto $(C)$ - São Paulo - 2013............................................

Figura 2 - $\quad$ Tronco de contenção onde foram realizados exame específico do aparelho mamário e colheita de amostras, exceto as alíquotas destinadas ao exame bacteriológico e separação dos fagócitos, São Paulo - 2013.

Figura 3 - Sala de ordenha onde foram colhidas as alíquotas destinadas ao exame bacteriológico e obtenção dos fagócitos da secreção mamária, São Paulo - 2013.

Figura 4 - $\quad$ Avaliação da GM pela técnica de inspeção: (A) vista posterior; (B) vista lateral direita; $(C)$ vista lateral esquerda de aparelho mamário considerado simétrico; (D) vista posterior; (E) vista lateral direita; (F) vista lateral esquerda de GM assimétrica São Paulo - 2013.

Figura 5 - $\quad$ Avaliação da GM pela técnica de palpação: (A) palpação do parênquima mamário; (B) palpação dos linfonodos retromamários - São Paulo - 2013.

Figura 6 - Obtenção de uma suspensão celular concentrada a partir de $1 \mathrm{~L}$ de colostro bovino. (a) - um litro de colostro diluído em PBS (1:1); (b) - A solução colostro +PBS foi transferida para frascos específicos para centrifugação, em destaque é possível observar o pellet celular após o processo de centrifugação; (c) Ressuspensão do pellet em PBS; (d) Em destaque está o pellet celular, após centrifugação; (e) Ressuspensão de pellet celular em PBS; (f) Transferência do pellet ressuspenso para tubos cônicos; (g) Pellet celular obtido após centrifugação, e ressuspendido em $10 \mathrm{~mL}$ de PBS; (h) Suspensão celular concentrada - São Paulo - 2013

Figura 7 - Avaliação da viabilidade celular pela prova de exclusão de Azul de tripan. Secreção mamária apresentando viabilidade alta (A) e viabilidade baixa (B) em vacas Holandesas - São Paulo, 2013

Figura 8 - Separação dos PMN do colostro: (A) Adição da suspensão de células do colostro ao Histopaque ${ }^{\circledR}$; (B) Aspecto bifásico da suspensão celular e Histopaque ${ }^{\circledR}$ antes da centrifugação; São Paulo - 2013.

Figura 9 - Separação dos PMN do colostro: (a) Separação das células em camadas após $1^{\circ}$ etapa de centrifugação (Células vivas; Debris Celulares); (b) Separação das células em camadas após centrifugação com Histopaque ${ }^{\circledR} 1083$ (Células Mononucleares; PMN) - São Paulo - 2013. 
Figura 10 - Avaliação da proporção de neutrófilos no sangue de vacas Holandesas no período de transição: (A) Distribuição dos leucócitos sanguíneos; (B) Seleção dos neutrófilos $\mathrm{CH} 138^{+}$em relação ao total de eventos adquiridos - São Paulo - 2013.......

Figura 11 - Avaliação da proporção de neutrófilos $\mathrm{CH}_{138^{+}}$no colostro de vacas Holandesas: (A) Distribuição dos leucócitos do colostro proveniente de glândula mamária infectada, após separação das células PMN por gradiente de densidade; (B) Seleção dos neutrófilos $\mathrm{CH}_{138^{+}}$em relação ao total de eventos adquiridos São Paulo - 2013

Figura 12 - Avaliação da proporção de neutrófilos do leite de vacas Holandesas no período de transição: (A) Distribuição dos leucócitos sanguíneos totais do leite; (B) Seleção dos neutrófilos $\mathrm{CH}_{138^{+}}$em relação ao total de eventos adquiridos São Paulo - 2013

Figura 13 - Avaliação da fagocitose das células $\mathrm{CH}_{138^{+}}$do sangue de vacas Holandesas no periparto: (A) Seleção das células $\mathrm{CH}_{138^{+}}$(FL4) em relação ao total de eventos adquiridos; (B) Proporção de células $\mathrm{CH}_{138^{+}}$que fagocitaram bactéria marcada (FL2) - São Paulo - 2013........................................

Figura 14 - Avaliação da produção de $\mathrm{H}_{2} \mathrm{O}_{2}$ pelas células $\mathrm{CH}_{138^{+}}$do sangue de vacas Holandesas no período de transição: (A) Seleção da população $\mathrm{CH}_{138^{+}}$(FL4) em relação ao total de eventos adquiridos; (B) Seleção do eixo FL1 para avaliação da produção de $\mathrm{H}_{2} \mathrm{O}_{2}$ basal pelas células $\mathrm{CH}_{138^{+}}$(FL4); (C) Seleção do eixo $\mathrm{FL} 1$ para avaliação da produção de $\mathrm{H}_{2} \mathrm{O}_{2}$ com baixa (Low - população esquerda) e alta fluorescência (High população direita) pelos neutrófilos $\mathrm{CH}_{138^{+}}$(FL4) com estímulo bacteriano - São Paulo - 2013

Figura 15 - Avaliação da fagocitose das células $\mathrm{CH} 138^{+}$do colostro de vacas Holandesas: (A) Seleção das células $\mathrm{CH}_{138^{+}}$(FL4) em relação ao total de eventos adquiridos e após separação das amostras por gradiente de densidade; (B) Proporção de células $\mathrm{CH}_{138^{+}}$que fagocitaram Staphylococcus aureus (C) e Escherichia coli - São Paulo - 2013

Figura 16 - Avaliação da produção de $\mathrm{H}_{2} \mathrm{O}_{2}$ pelas células $\mathrm{CH} 138^{+}$do colostro de vacas Holandesas. (A) Seleção da população $\mathrm{CH}_{138^{+}}$(FL4) em relação ao total de eventos adquiridos. (B) Seleção do eixo $F L 1$ para avaliação da produção de $\mathrm{H}_{2} \mathrm{O}_{2}$ basal pelas células $\mathrm{CH}_{138^{+}}$(FL4). (C) Seleção do eixo FL1 para avaliação da produção de $\mathrm{H}_{2} \mathrm{O}_{2}$ com baixa (Low população esquerda) e alta fluorescência (High - alta fluorescência), respectivamente, pelos $\mathrm{CH}_{138^{+}}$(FL4) com estímulo bacteriano - São Paulo - 2013 
Figura 17 - Avaliação da produção de $\mathrm{H}_{2} \mathrm{O}_{2}$ pelas células $\mathrm{CH}_{138^{+}}$do leite de vacas Holandesas. (A) Seleção da população $\mathrm{CH}_{138^{+}}$(FL4) em relação ao total de eventos adquiridos. (B) Seleção do eixo FL1 para avaliação da produção de $\mathrm{H}_{2} \mathrm{O}_{2}$ basal pelas células $\mathrm{CH}_{138^{+}}$(FL4). (C) Seleção do eixo $\mathrm{FL} 1$ para avaliação da produção de $\mathrm{H}_{2} \mathrm{O}_{2}$ com baixa (Low - população esquerda) e alta fluorescência (High - alta fluorescência), respectivamente, pelos $\mathrm{CH}_{138^{+}}$(FL4) com estímulo bacteriano - São Paulo 2013.

Figura 18 - Frequências (\%) de resultados negativos e positivos ao exame bacteriológico da secreção mamária de vacas Holandesas no período de transição - São Paulo, 2013.

Figura 19 - Proporção (\%) de células $\mathrm{PMN}(\mathrm{A})$ e $\mathrm{CH}_{138^{+}}$(B) no sangue de vacas Holandesas no período de transição - São Paulo, 2013...

Figura 20 - Valor absoluto (VA) de leucócitos PMN e neutrófilos $\mathrm{CH} 138^{+}$ presentes no sangue de vacas Holandesas durante o período de transição - São Paulo, 2013

Figura 21 - Proporção (\%) (A) e intensidade da fagocitose (B) de Staphylococcus aureus pelos neutrófilos $\mathrm{CH}_{138^{+}}$sanguíneos de vacas Holandesas no período de transição - São Paulo, 2013.

Figura 22 - Proporção (\%) (A) e intensidade da fagocitose (B) de Escherichia coli pelos neutrófilos $\mathrm{CH} 138^{+}$sanguíneos de vacas Holandesas no período de transição - São Paulo, 2013.

Figura 23 - Proporção (\%) (A) e intensidade (Média Geométrica) (B) da produção basal de peróxido de hidrogênio pelos neutrófilos sanguíneos $\mathrm{CH}_{138^{+}}$de vacas Holandesas no período de transição - São Paulo, 2013.

Figura 24 - Produção de peróxido de hidrogênio pelos neutrófilos sanguíneos $\mathrm{CH} 138+$ (Low) estimulados com Staphylococcus aureus: (A) - Proporção (\%); (B) - Intensidade (Média Geométrica) em vacas Holandesas no período de transição São Paulo, 2013.

Figura 25 - Produção de peróxido de hidrogênio pelos neutrófilos sanguíneos $\mathrm{CH} 138+$ (High) estimulados com Staphylococcus aureus: (A) - Proporção (\%); (B) - Intensidade (Média Geométrica) em vacas Holandesas no período de transição São Paulo, 2013.

Figura 26 - Produção de peróxido de hidrogênio pelos neutrófilos sanguíneos $\mathrm{CH} 138+$ (Low) estimulados com Escherichia coli: (A) - Proporção (\%); (B) - Intensidade (Média Geométrica) em vacas Holandesas no período de transição - São Paulo, 2013.. 90 
Figura 27 - Produção de peróxido de hidrogênio pelos neutrófilos sanguíneos $\mathrm{CH} 138+$ (High) estimulados com Escherichia coli: (A) - Proporção (\%); (B) - Intensidade (Média Geométrica) em vacas Holandesas no período de transição - São Paulo, 2013..

Figura 28 - Mediana da contagem de células somáticas (CCS) no colostro e leite de vacas Holandesas no pós-parto - São Paulo, 2013.... 92

Figura 29 - Proporção (\%) de células totais viáveis, obtidas no colostro e leite de vacas Holandesas no pós-parto - São Paulo, 2013........

Figura 30 - Proporção (\%) de neutrófilos $\mathrm{CH}_{138^{+}}$presentes no leite de vacas Holandesas no pós-parto - São Paulo, 2013.

Figura 31 - Proporção (\%) (A) e intensidade da fagocitose (B) de Staphylococcus aureus pelos neutrófilos $\mathrm{CH} 138^{+}$do colostro e leite de vacas Holandesas no período de transição - São Paulo, 2013

Figura 32 - Proporção (\%) (A) e intensidade da fagocitose (B) de Escherichia coli pelos neutrófilos $\mathrm{CH}_{138^{+}}$do colostro e leite de vacas Holandesas no período de transição - São Paulo, 2013

Figura 33 - Proporção (\%) (A) e intensidade (Média Geométrica) (B) da produção basal de peróxido de hidrogênio pelos neutrófilos $\mathrm{CH} 138^{+}$do colostro e leite de vacas Holandesas no período de transição - São Paulo, 2013

Figura 34 - Produção de peróxido de hidrogênio pelos neutrófilos $\mathrm{CH} 138+$ (Low) do colostro e leite, estimulados com Staphylococcus aureus: (A) - Proporção (\%); (B) - Intensidade (Média Geométrica) em vacas Holandesas no período de transição São Paulo, 2013

Figura 35 - Produção de peróxido de hidrogênio pelos neutrófilos $\mathrm{CH} 138+$ (High) do colostro e leite, estimulados com Staphylococcus aureus: (A) - Proporção (\%); (B) - Intensidade (Média Geométrica) em vacas Holandesas no período de transição São Paulo, 2013.

Figura 36 - Produção de peróxido de hidrogênio pelos neutrófilos $\mathrm{CH} 138+$ (Low) do colostro e leite, estimulados com Escherichia coli: (A) - Proporção (\%); (B) - Intensidade (Média Geométrica) em vacas Holandesas no período de transição - São Paulo, 2013..

Figura 37 - Produção de peróxido de hidrogênio pelos neutrófilos $\mathrm{CH} 138+$ (High) do colostro e leite, estimulados com Escherichia coli: (A) - Proporção (\%); (B) - Intensidade (Média Geométrica) em vacas Holandesas no período de transição - São Paulo, 2013.. 
Figura 38 - (A) Placa com crescimento da bactéria Staphylococcus aureus; (B) Placa com crescimento da bactéria Escherichia coli; (C) Totalidade das bactérias recolhidas das placas - à esquerda E. coli e à direta S. aureus; (D) Bactérias marcadas com PI; (E) Botão de bactérias marcadas com PI em etapa final de processamento - São Paulo, 2013 ......................................... 


\section{LISTA DE QUADROS}

Quadro 1 - Cronologia das avaliações realizadas no sangue e secreção mamária (SM) de Holandesas no período de transição São Paulo, 2013.

Quadro 2 - Parâmetros e quesitos adotados no exame específico da GM - São Paulo, 2013.

Quadro 3 - Ensaio de fagocitose, produção de $\mathrm{H}_{2} \mathrm{O}_{2}$ e proporção (\%) de neutrófilos $\mathrm{CH} 138^{+}$do sangue e secreção mamária de vacas Holandesas - São Paulo, 2013...................................

Quadro 4 - Ocorrência de doenças da produção em vacas Holandesas no período de transição- São Paulo, 2013.............................

Quadro 5 - Identificação, ordem e data de parição das fêmeas bovinas

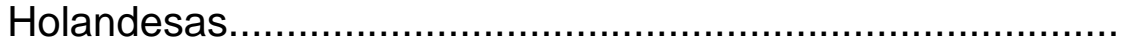

Quadro 6 - Status de higidez do aparelho mamário na semana -4 - São

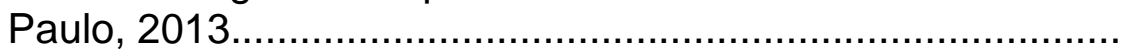




\section{LISTA DE ABREVIATURAS E SIGLAS}

GM Glândula Mamária

$\mathrm{Kg} \quad$ Quilograma

PMN Polimorfonucleares

Ig Imunoglobulina

LPS Lipopolissacarídeo

IL Interleucina

INF Interferon

PAMPs "Pathogen-Associated Molecular Pattern"

PRRs "Pattern Recognition Receptors"

TLR Receptores tipo Toll (Do inglês: Toll like receptors)

NF $\quad$ Fator Nuclear (Do inglês: Nuclear Factor)

EROs Espécies Reativas de Oxigênio

SOD Superóxido desmutase

$\mathrm{H}_{2} \mathrm{O}_{2} \quad$ Peróxido de Hidrogênio

NO Óxido Nítrico

PI lodeto de propídeo (Do inglês: Propidium iodide)

DCDH-DA Dichlorofluorescein diacetate

DHR Dihydrorhodamine

TNF Fator de Necrose Tumoral (Do inglês: Tumor Necrosis Factor)

CCS Contagem de células somáticas

PMA Acetato de Forbol Miristato (Do inglês: Phorbol Myristate Acetate)

CL Quimiluminescência (Do inglês: Chemiluminescence)

APTA Agência Paulista de Tecnologia dos Agronegócios

SM Secreção Mamária

FE $\quad$ Fundo Escuro

RI Resposta Imune

M Momento

Ml Mililitro 
PBS Tampão fostato salino (Do inglês: Phosphate Buffered Saline)

EDTA Ácido etilenodiaminotetracético (Do inglês: Ethylenediamine tetraacetic acid)

$\mu \mathrm{L} \quad$ Microlitro

SFB Soro fetal bovino

mM Milimol

$\mathrm{NaCl} \quad$ Cloreto de Sódio

APC Allophycocyanin

ELISA Ensaio imuno enzimático (Do inglês: Enzyme-linked Immunosorbent Assay)

S. aureus Staphylococcus aureus

E. coli Escherichia coli 


\section{LISTA DE SÍMBOLOS}

B Beta

Y Gama

к Kappa

a Alpha

$\geq \quad$ Maior ou igual

$<$ Menor

\% Porcentagem

${ }^{\circ} \mathrm{C}$ Graus Celsius

${ }^{\circledR}$ Marca registrada

$\mathrm{xg}$ Força $\mathrm{g}$ 
$1 \quad$ INTRODUÇÃO

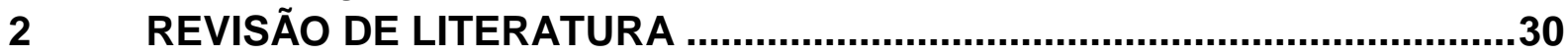

2.1 IMUNOBIOLOGIA DA GLÂNDULA MAMÁRIA NO PERIPARTO ..................30

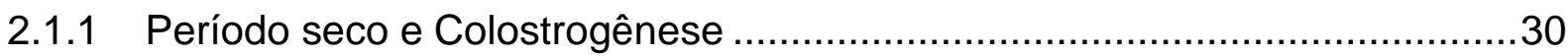

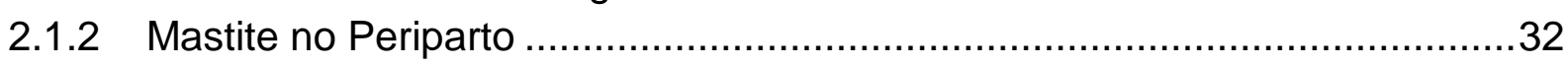

2.2 ATIVIDADE FUNCIONAL DE NEUTRÓFILOS PMN ...............................34

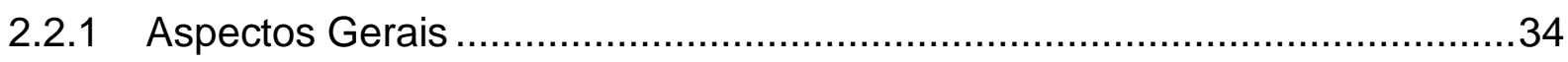

2.2.2 Função dos Neutrófilos Sanguíneos no Periparto ........................................36

2.2.3 Função dos neutrófilos PMN da Glândula Mamária no Periparto...................38

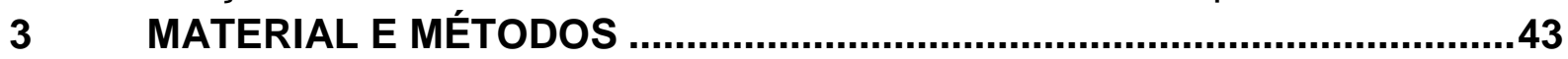

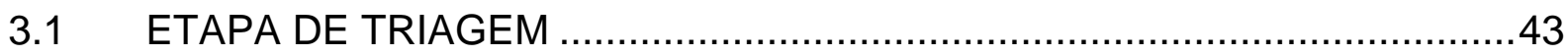

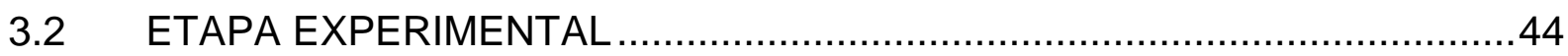

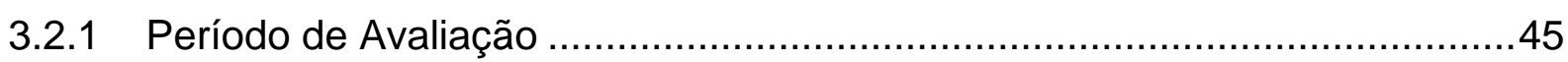

3.2.2 Exame específico da glândula mamária..................................................47

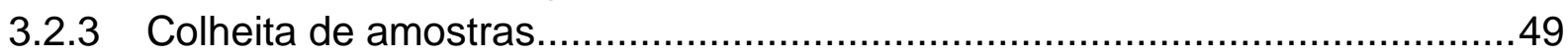

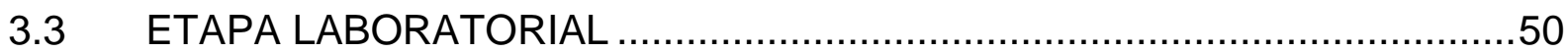

3.3.1 Exame Bacteriológico ......................................................................50

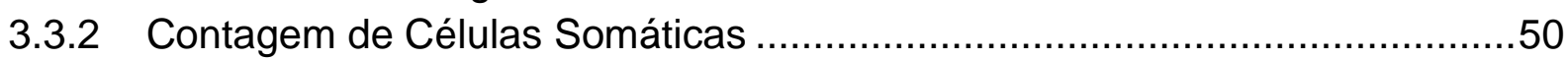

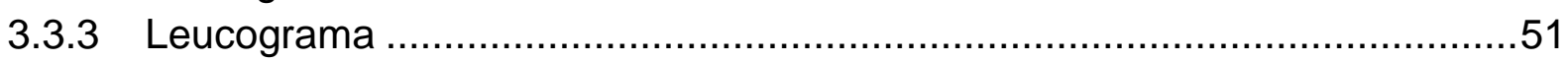

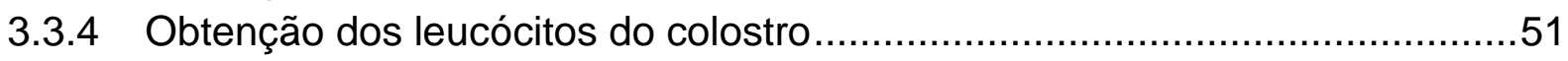

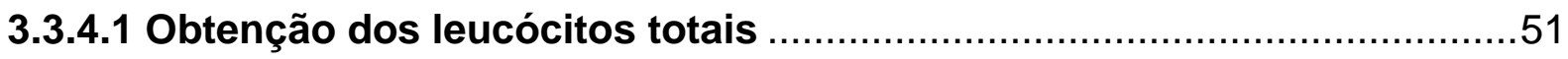

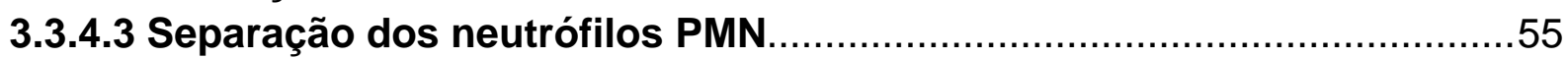

3.3.4.4 Obtenção dos leucócitos do leite ....................................................57

3.3.5 Proporção e avaliação funcional dos neutrófilos $\mathrm{CH} 138^{+}$do sangue e

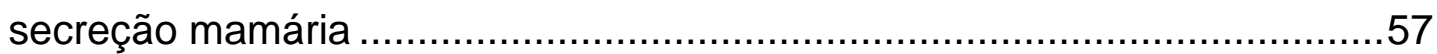

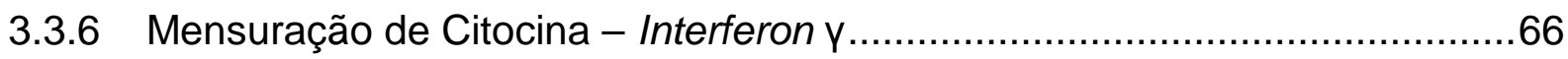

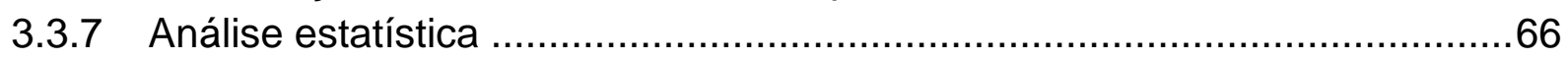

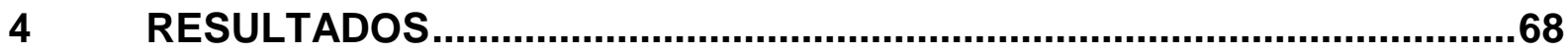

4.1 DOENÇAS DA PRODUÇÃO NO PERÍODO DE TRANSIÇÃO …................68

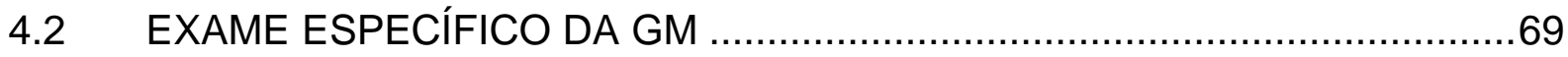

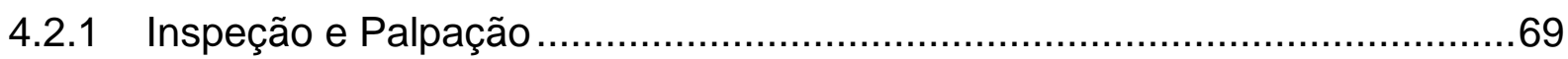

4.3 EXAME BACTERIOLÓGICO DO LEITE ….............................................

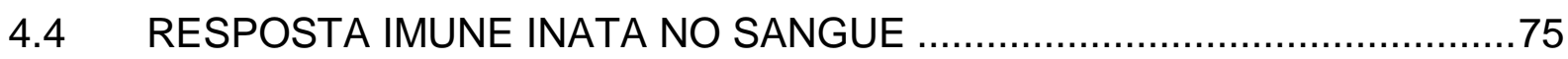

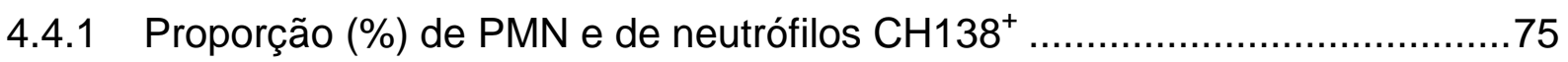

4.4.2 Valores absolutos de leucócitos totais e neutrófilos $\mathrm{CH} 138^{+} \ldots \ldots \ldots \ldots \ldots \ldots \ldots . . . . . .77$

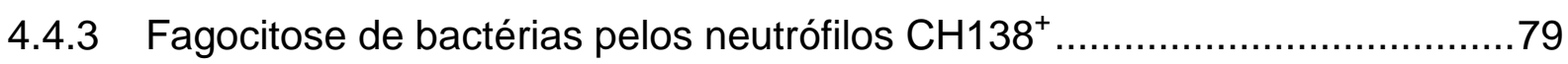

4.4.3.1 Fagocitose de Staphylococcus aureus ............................................79

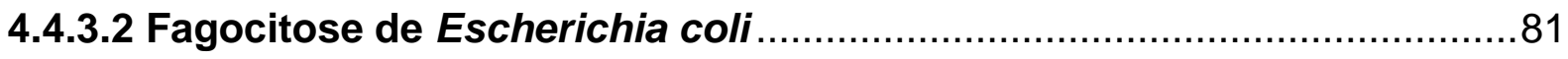

4.4.4 Produção intracelular de peróxido de hidrogênio $\left(\mathrm{H}_{2} \mathrm{O}_{2}\right)$ pelos neutrófilos

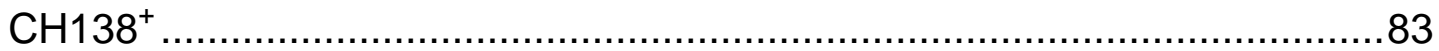

4.4.4.1 Produção de $\mathrm{H}_{2} \mathrm{O}_{2}$ pelos $\mathrm{CH} 138^{+}$Basal ............................................83

4.4.4.2 Produção de $\mathrm{H}_{2} \mathrm{O}_{2}$ pelos $\mathrm{CH}_{138^{+}}$estimulados com Staphylococcus aureus. 
4.4.4.3 Produção de $\mathrm{H}_{2} \mathrm{O}_{2}$ pelos $\mathrm{CH}_{138^{+}}$estimulados com Escherichia coli .....88

4.5 RESPOSTA IMUNE INATA DA GLÂNDULA MAMÁRIA ................................

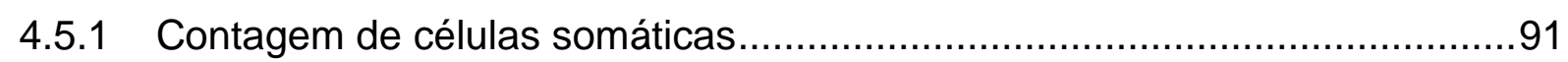

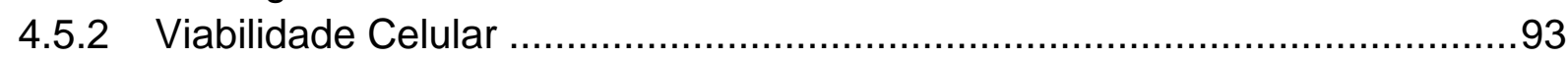

4.5.3 Concentração de células viáveis ..............................................................94

4.5.4 Pureza da suspensão de PMN do colostro - Proporção $\mathrm{CH} 138^{+}$.................95

4.5.5 Proporção de neutrófilos $\mathrm{CH} 138^{+}$do leite ...............................................96

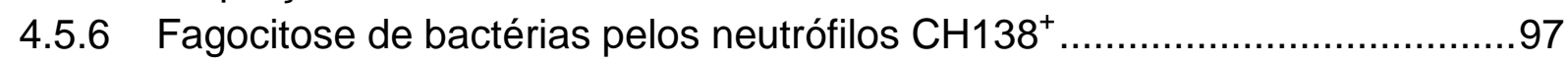

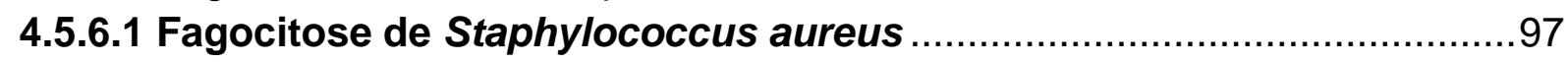

4.5.6.2 Fagocitose de Escherichia coli.......................................................99

4.5.7 Produção intracelular de peróxido de hidrogênio $\left(\mathrm{H}_{2} \mathrm{O}_{2}\right)$ pelos neutrófilos

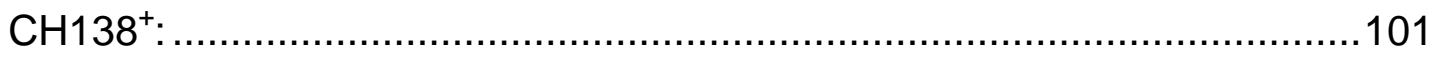

4.5.7.1 Produção de $\mathrm{H}_{2} \mathrm{O}_{2}$ pelos $\mathrm{CH}_{138}{ }^{+}$Basal ..........................................101

4.5.7.2 Produção de $\mathrm{H}_{2} \mathrm{O}_{2}$ pelos $\mathrm{CH}_{138^{+}}$estimulados com Staphylococcus

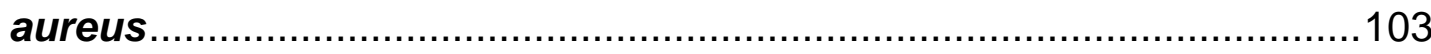

4.5.7.3 Produção de $\mathrm{H}_{2} \mathrm{O}_{2}$ pelos $\mathrm{CH}_{138}{ }^{+}$estimulados com Escherichia coli...106

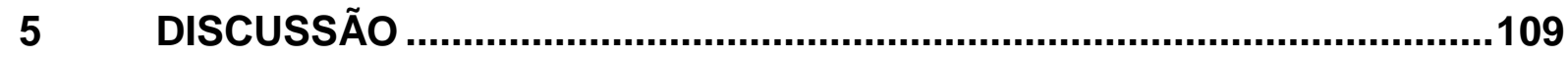

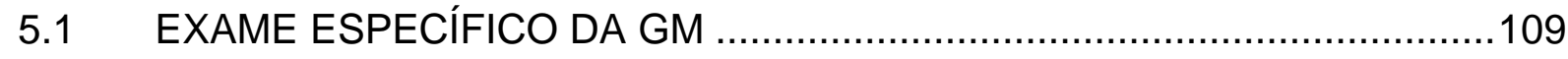

5.2 EXAME BACTERIOLÓGICO DO LEITE ..............................................110

5.3 RESPOSTA IMUNE INATA NO SANGUE …….................................111

5.4 RESPOSTA IMUNE INATA DA GLÂNDULA MAMÁRIA ...........................114

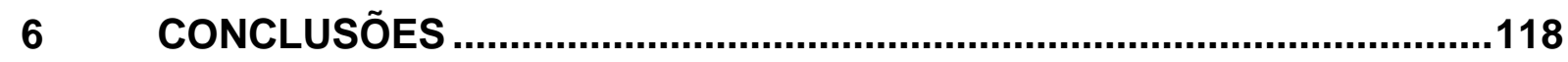

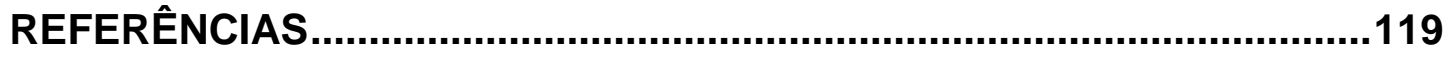

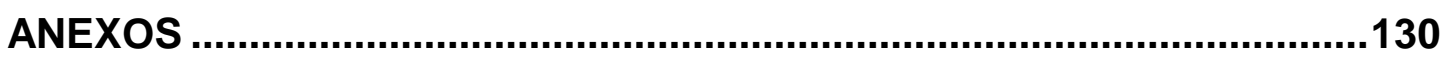

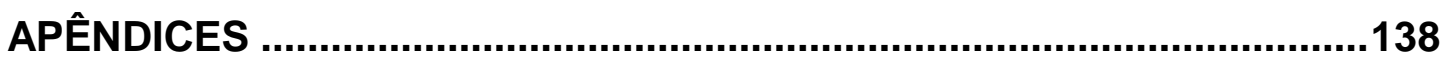




\section{INTRODUÇÃO}

O período de transição (periparto) abrange 21 dias pré a 21 dias pós-parto (VAN KAMPEN; MALLARD, 1997). Este período é marcado por mudanças imunes e fisiológicas do estado geral e da glândula mamária (GM) das fêmeas bovinas, principalmente pela proximidade ao parto e colostrogênese (HIBBIT; CRAVEN; BETTEN, 2008).

A colostrogênese é uma fase de risco para mastite, marcada por altos índices de infecção mamária, superiores aos observados na fase de lactação (EBERHART, 1986; NEWMAN et al., 2009; HOGAN; SMITH, 2012). Esta doença é considerada o principal e mais oneroso problema da cadeia produtiva de leite, causando perdas econômicas decorrentes de custos com tratamento, assistência veterinária, mão de obra adicional, descarte precoce do animal, diminuição na produção e qualidade do leite, além disso, pode contribuir para o aparecimento de outras enfermidades concomitantes (HEIKKILÄ; NOUSIAINEN; PYÖRÄLÄ, 2012). Rajala-Schultz et al. (1999) verificaram perdas na produção correspondente a 110-552 Kg (quilograma) de leite em uma lactação por vaca acometida.

Neste contexto, diversas pesquisas têm sido realizadas com o intuito de entender a dinâmica das células sanguíneas e da secreção mamária no período de transição, demonstrando que a resposta imune inata, principalmente a função fagocítica e bactericida dos neutrófilos do sangue e leite, está comprometida especialmente no pós-parto imediato. A função dos polimorfonucleares da secreção mamária foi avaliada em GM hígida ou com mastite experimental, a partir do terceiro dia pós-parto (WALLER, 2000; MEHRZAD et al., 2001, 2002; MEHRZAD; DUCHATEAU; BURVENICH, 2004; RINALDI; MORONI; PAAPE, 2008; MEHRZAD; DUCHATEAU; BURVENICH, 2009).

A proximidade ao parto está extremamente relacionada à diminuição da atividade dos neutrófilos da secreção mamária. Gomes et al. (2011) e Gomes et al. 
(2014 no prelo ${ }^{1}$ ) avaliaram a proporção das células e função dos fagócitos do colostro bovino. Nesta pesquisas verificaram que o colostro de $1^{\circ}$ ordenha apresenta apenas 8 a 12\% de neutrófilos e relacionaram tal achado com a susceptibilidade da GM às mastites no pós-parto imediato, no entanto, dificuldades para separação dos polimorfonucleares (PMN) do colostro dentre os demais componentes celulares e debris corroboram para a ausência de resultados específicos do colostro bovino de primeira ordenha.

A motivação para realização desta pesquisa foi à importância do período de transição para a ocorrência de doenças da produção, a alta freqüência de mastite no período de colostrogênese e ausência de pesquisas avaliando a atividade funcional dos neutrófilos PMN do colostro, mediante exposição natural aos patógenos. A hipótese desse trabalho é que as adaptações fisiológicas e imunes ocorridas no período periparto, incluindo a colostrogênese, comprometem a resposta imune inata da glândula mamária, tornando-a susceptível às infecções bacterianas. Portanto, o objetivo desta pesquisa foi avaliar mecanismos da resposta imune inata no sangue, colostro e leite de vacas no período de transição, mediante exposição natural aos patógenos bacterianos.

\footnotetext{
${ }^{1}$ GOMES, V.; MADUREIRA, K. M.; SORIANO, S.; PONTES, G. N.; SILVA, B. T.; BENESI, F. J. Release of hydrogen peroxide by phagocytes from bovine colostrum in the peripartum period. Acta Veterinaria Brno, 2014.
} 


\section{REVISÃO DE LITERATURA}

A revisão de literatura foi elaborada a partir dos principais trabalhos e pesquisas realizadas com foco na imunobiologia da GM no periparto e atividade funcional dos neutrófilos PMN.

\subsection{IMUNOBIOLOGIA DA GLÂNDULA MAMÁRIA NO PERIPARTO}

Abaixo, serão apresentadas algumas particularidades do período periparto.

\subsubsection{Período seco e Colostrogênese}

A diminuição da capacidade secretora das células epiteliais mamárias em vacas gestantes no final da lactação pode ser atribuída ao conflito metabólico entre lactação e gestação. Nesta fase, a secagem das vacas é realizada, ao redor de 60 dias pré-parto, com o objetivo de priorizar a gestação e iniciar um novo ciclo produtivo (CAPUCO; AKERS; SMITH, 1997). A diminuição do parênquima mamário ocorre gradualmente durante a lactação, desta forma, a morte celular por apoptose no período seco é limitada. A menor capacidade secretora das células epiteliais neste período pode ser atribuída ao não desenvolvimento das células sobreviventes no tecido mamário (WILDE et al., 1997)

Capuco e Akers (1999) não verificaram diminuição do tecido mamário no período seco de 60 dias, através da avaliação combinada da morfologia do tecido com a análise do DNA total do úbere, observando que as estruturas alveolares permaneceram intactas. O remodelamento da GM, que envolve a morte por apoptose e proliferação celular, ocorre continuamente ao longo da lactação estabelecida (CAPUCO et al., 2001), porém o período seco é importante para a substituição das células senescentes e danificadas do epitélio mamário, aumentando 
o componente epitelial da glândula antes da próxima lactação. As células repostas podem ser as responsáveis pela expansão e manutenção das células secretoras da glândula mamária (CAPUCO; AKERS; SMITH, 1997), influenciando a sua produção de leite na lactação posterior (SORENSEN; ENEVOLDSEN, 1991).

A colostrogênese se inicia semanas antes do parto e cessa abruptamente no momento do parto sob influencias hormonais como a prolactina que é necessária para que ocorra diferenciação estrutural e funcional das células mamárias (BRANDON; WATSON; LASCELLES, 1971; McFADDEN; BESSER; BARRINGTON, 1997; BARRINGTON et al., 2001;). Estudos realizados com o intuito de induzir lactação artificial, através da aplicação de progesterona e estrógeno, demonstraram aumento da lg (imunoglobulina) G1 na secreção mamária, antes da lactação subsequente (SMITH; SCHANBACHER, 1973; WINGER; GAY; BESSER, 1995), porém o mecanismo como esses hormônios influenciam a colostrogênese ainda não é claramente estabelecido (BARRINGTON et al., 2001).

O processo de colostrogênese resulta no edema fisiológico da glândula mamária, observado em 95\% das vacas (DENTINE; MC DANIEL, 1983). Este fato é resultante do aumento do fluxo sanguíneo necessário para a colostrogênese e demanda de nutrientes para a GM (HIBBIT; CRAVEN; BETTEN, 2008). Outros fatores também podem contribuir, como influências hormonais, dieta no período pré-parto contendo altos níveis de sódio e potássio (RANDALL et al., 1974), e danos ao tecido mamário ocorridos pelo estresse oxidativo decorrentes de processos inflamatórios e status da GM no período (NRC, 2001). Além disso, autores relatam que o edema da GM é um fator de risco para a ocorrência de mastite nos 30 dias pós-parto (VAN DORP et al., 1999; WAAGE et al., 2001).

O colostro é constituído principalmente por imunoglobulinas, sendo lgG1 o isotipo predominante, constituindo mais de $90 \%$ de todas as proteínas dessa secreção (LARSON, 1992). Em conjunto com as imunoglobulinas, o colostro e leite contêm células viáveis que secretam uma gama de componentes relacionados ao sistema imunológico, incluindo citocinas, proteínas e peptídeos antimicrobianos (STELWAGEN et al., 2009). Além da proteção aos neonatos, estes fatores imunológicos desempenham um papel importante na defesa da glândula mamária contra a invasão de patógenos (OVIEDO-BOYSO; VALDEZ-ALARCÓN; CAJEROJUÁREZ, 2007). 
A transferência da lgG1 do soro para o colostro é explicada através de um processo mediado por receptores específicos para essa imunoglobulina (BUTLER, 1983). A IgG1 se liga ao seu receptor específico (porção Fc) que está localizado na superfície basi-lateral das células epiteliais alveolares (KEMLER et al., 1975), observando endocitose, transporte da lgG1 através das células em vesículas e liberação dessa imunoglobulina na superfície apical para o colostro (BUTLER, 1983; LARSON, 1985).

A colostrogênese e composição do colostro priorizam a imunização passiva de bezerras recém-nascidas, porém o cenário pode não ser favorável para a defesa da glândula mamária (GOMES, 2008).

\subsubsection{Mastite no Periparto}

O período seco tem sido considerado crítico no aparecimento da mastite bovina, observando altas taxas de novas infecções mamárias quando comparada a fase de lactação (SMITH et al., 1985). As infecções mamárias que se iniciaram durante este período ou que persistiram da lactação anterior na forma inaparente, manifestam-se clinicamente na lactação subseqüente (TODHUNTER; SMITH; HOGAN, 1995; BRADLEY; GREEN, 2000). As três primeiras semanas do período seco e nos instantes pré e pós-parto imediatos são fases críticas para aparecimento de novas infecções mamárias (EBERHART, 1986).

Estudos demonstraram que $52 \%$ de todas as mastites aparentes, causadas por coliformes, isoladas nos primeiros 100 dias de lactação, tiveram início no período seco (BRADLEY; GREEN, 2000). Das infecções mamárias causadas por Streptococcus ambientais, 91\% surgiram no período seco (TODHUNTER; SMITH; HOGAN, 1995).

Os patógenos ambientais e contagiosos têm relevância no aparecimento de infecções mamárias no período seco. Os patógenos contagiosos de maior importância são Staphylococcus aureus, Streptococcus agalactiae e Mycoplasma bovis. Como patógenos ambientais, podemos citar Streptococcus uberis, Streptococcus dysgalactiae (gram positivas), Escherichia coli, Klebsiella (gram negativas), e Enterobacter (NMC, 1999). Como patógenos considerados menores, 
podemos citar os Staphylococcus coagulase-negativa, que podem ser encontrados na pele do teto, e Corynebacterium bovis que tem por principal reservatório as glândulas mamárias e ductos dos tetos infectados (RADOSTITIS et al., 2002). Além destes, podemos citar as mastites causadas por Prototheca, Pasteurella, Arcanobacterium pyogenes, e Pseudomonas (EBERHART, 1986).

A via de entrada destes patógenos é ascendente e pode ser facilitada pela presença de fatores de risco no período de transição. Além das mudanças anatômicas ocorridas no periparto, como o aumento da glândula mamária, edema fisiológico e aproximação dos tetos ao solo, existem fatores imunes ligados à função dos neutrófilos que tem sido associados com a predisposição dos animais às doenças infecciosas nesse período (SLÁDEK; RYSÁNEK, 2001; KIMURA et al., 2002; PAAPE et al., 2002; MEHRZAD; DUCHATEAU; BURVENICH, 2004; VANGROENWEGHE; LAMOTE; BURVENICH, 2005; HAMMON et al., 2006; SHELDON et al., 2006; RINALDI; MORONI; PAAPE, 2008;)

A associação entre patógenos invasores e o sistema imune é o fator determinante para o desencadeamento da infecção. Resposta inflamatória eficiente é necessária para eliminação bacteriana sem manifestações clínicas evidentes e alterações perceptíveis na qualidade e produção de leite, porém a ineficiência dessa resposta promove estabelecimento da infecção e lesões no parênquima mamário (SORDILLO, 2005).

O quadro clínico observado nesta fase do ciclo produtivo dependerá do estabelecimento clínico ou não da infecção, e dos patógenos envolvidos, porém de uma maneira geral, a mastite se manifesta com diminuição da produção de leite, aumento de volume e rubor da glândula mamária ou quartos acometidos, dor, aumento da temperatura local ou sistêmica, podendo chegar até ao óbito dos animais doentes (RUEGG, 2011). 


\subsection{ATIVIDADE FUNCIONAL DE NEUTRÓFILOS PMN}

A seguir será apresentada a revisão referente a atividade funcional dos neutrófilos PMN do sangue e secreção mamária em diferentes condições.

\subsubsection{Aspectos Gerais}

Os neutrófilos PMN constituem a primeira linha de defesa celular contra patógenos invasores (PAAPE et al., 2002). Estas células detêm um papel de extrema importância na resposta imune inata, pois reconhecem, fagocitam e destroem patógenos independentes da resposta imune adaptativa. São células de vida curta, pois perecem após um ciclo de fagocitose (MURPHY; TRAVERS; WALPORT, 2010).

O PMN é caracterizado pelo seu núcleo segmentado polimórfico, que permite com que se alinhe finamente, facilitando sua rápida migração entre as células endoteliais. Outra característica marcante dos PMN é a presença de grânulos citoplasmáticos, cuja principal função é promover a morte bacteriana (PAAPE et al., 2002). Além disso, o PMN também detém estoques de glicogênio, que são fontes de energia, e uma superfície complexa que conta com a presença de receptores específicos de superfície, que são usados no processo de fagocitose de bactérias e formação de vacúolos fagocíticos intracelulares (PAAPE et al., 2003)

Os neutrófilos dos bovinos têm grânulos azurofílicos e específicos em seu citoplasma, diferenciando-se de outras espécies pela presença de um terceiro tipo de grânulo, maiores, mais densos e numerosos (GENNARO et al., 1983; WOOD; QUIROZ-ROCHA, 2010).

A membrana plasmática do PMN contém diversos receptores, como as moléculas de adesão $L$-selectina e $\beta_{2}$ integrina, que são importantes no processo de migração desses para os locais da infecção (PAAPE et al., 2002).

Para a chegada do PMN no local da infecção, o mesmo precisa ser direcionado com o auxílio de quimioatraentes, que se ligam a receptores específicos 
na membrana plasmática do PMN. Importantes quimioatraentes no recrutamento do PMN bovino são componentes do complemento C5a, C3b, LPS (lipopolissacarídeo), IL (interleucina)-1, IL-2, IL-8 e Interferon Y (INF-Y) (GREWAL; ROUSE; BABIUK, 1978; GRAY et al., 1982; CRAVEN, 1986; DALEY et al., 1991; LEE; ZHAO 2000; CASWELL; MIDDLETON; GORDON, 2001).

Os microrganismos carregam padrões repetidos em sua superfície, comumente conhecidos como "Pathogen-Associated Molecular Pattern" (PAMPs) reconhecidos pelos "Pattern Recognition Receptors" (PRRs) presentes nos neutrófilos e macrófagos (MURPHY; TRAVERS; WALPORT, 2010).

A primeira etapa da fagocitose consiste no reconhecimento entre os PAMPs e os PRRs, sendo esse processo facilitado pela opsonização mediada pelas imunoglobulinas e componentes do complemento. O reconhecimento é feito pelos neutrófilos e macrófagos no sangue e tecidos (PAAPE et al., 2002).

Os receptores tipo Toll (TLRs) são PRRs específicos para diferentes componentes dos micro-organismos. O TLR-2 é essencial para a resposta dos macrófagos a diversos lipoglicanos presentes nas bactérias Gram positivas; o TLR-4 para o lipopolissacarídeos bacterianos (LPS ou endotoxina); e o TLR-5 para um componente do flagelo chamado de flagelina. A ligação do receptor tipo Toll gera sinais que ativam um fator NF (fator nuclear) $k B$, estimulando a produção de citocinas, enzimas e outras proteínas envolvidas nas funções antimicrobianas dos fagócitos ativados (ABBAS; LICHTMAN, 2007).

A fagocitose é um processo ativo iniciado pela ligação dos PAMPs aos PRRs da superfície de fagócitos, em seguida, os patógenos são circundados pela membrana fagocítica e então internalizado em uma vesícula conhecida como fagossoma, que se funde aos lisossomos e origina o fagolisossomo (PAAPE et al., 2002; MURPHY; TRAVERS; WALPORT, 2010). Nesta etapa ocorre a emissão de sinais, que ativam diversas enzimas como NADPH oxidase, que converte o oxigênio molecular em íon superóxido e radicais livres, que são conhecidos como espécies reativas de oxigênio (EROs), sendo convertidos pela enzima superóxido dismutase (SOD) em peróxido de hidrogênio $\left(\mathrm{H}_{2} \mathrm{O}_{2}\right)$.

Os EROs também podem ser convertidos por outras enzimas e reações químicas com íons de ferro originando hipoclorito e radicais hidroxila, substâncias microbicidas diretamente tóxicas para os micro-organismos fagocitados. Outra 
enzima conhecida, denominada "sintase do óxido nítrico induzível", catalisa a conversão da arginina em óxido nítrico (NO), substância que também possui atividade microbicida. $O$ terceiro conjunto de enzimas são as proteases lisossômicas que quebram as proteínas microbianas, causando assim a sua destruição (ABBAS; LICHTMAN, 2007; MURPHY; TRAVERS; WALPORT, 2010).

Além dos mecanismos comumente conhecidos, recentes descobertas demonstram que os neutrófilos podem destruir bactérias através de mecanismos extracelulares. Estas células ativadas podem formar armadilhas extracelulares, que consiste na formação de redes de fibra composta por cromatinas e proteases de serina que prendem e destroem as bactérias. Estudos sugerem que estas armadilhas têm alta concentração de substâncias antimicrobianas que se ligam e destrôem bactérias sem que ocorra o processo de fagocitose pelas células presentes na GM, sendo importantes no combate à mastite (LIPPOLIS et al., 2006; GRINBERG et al., 2008).

A maioria dos neutrófilos perece após um ciclo de fagocitose e são eliminados pelos macrófagos (PAAPE et al., 2002).

\subsubsection{Função dos Neutrófilos Sanguíneos no Periparto}

O período periparto é caracterizado por mudanças fisiológicas, metabólicas, nutricionais (GOFF; HORST, 1997) e enfraquecimento da resposta imune do hospedeiro (WALLER, 2000).

Vários estudos têm sido realizados com o intuito de avaliar a atividade funcional dos PMN do sangue durante o período periparto, na tentativa de elucidar se a elevada incidência e/ou severidade de certas doenças infecciosas, como a mastite e inflamações uterinas, podem ser correlacionadas com a função prejudicada dos neutrófilos (KIMURA et al., 2002; VANGROENWEGHE; LAMOTE; BURVENICH, 2005; HAMMON et al., 2006; SHELDON et al., 2006; RINALDI; MORONI; PAAPE, 2008).

A transição de um estado de prenhez para lactação causa um grande estresse na vaca, observando resposta inata debilitada em fêmeas parturientes 
versus não-parturiente (BABIOR, 1984; KERHLI et al., 1989; CAl et al., 1994; MOREIRA DA SILVA et al., 1998). A diminuição da função dos PMN é marcante no pós-parto imediato devido à menor atividade das enzimas mieloperoxidase e NADPH-oxidase (KERHLI et al., 1989; MEHRZAD et al., 2001, 2002). A padronização da técnica de citometria de fluxo para avaliação simultânea da fagocitose e produção de espécies reativas de oxigênio de neutrófilos PMN do sangue foi padronizado em humanos por Hirabayashi; Taniuchi; Kobayashi (1985) e Hasui; Hirabayashi; Kobayashi (1989). Em bovinos, essa técnica foi inicialmente realizada por Smits; Burvenich; Heyneman (1997) e Kampen; Tollesrud; Lund (2004).

Smits; Burvenich; Heyneman (1997) identificaram os PMN sanguíneos pelo seu tamanho e granulosidade; a fagocitose foi estimulada pela Staphylococcus aureus marcadas com iodeto de propídeo $(\mathrm{PI})$; e a produção de ERO com as probes DCDH-DA (2', 7'- dichlorofluorescein diacetate) ou DHR (dihydrorhodamine 123), optando-se pelo uso final do DHR nas análises pela maior intensidade da fluorescência emitida. A média geométrica da fluorescência vermelha (fagocitose) emitida variou entre 252 a 408; para a fluorescência verde (EROS) variou entre 319 e 2254 usando DHR. Houve variação individual significante na fagocitose de Staphylococcus aureus $(P<0,05)$ e produção de EROS, verificando que maiores concentrações de bactérias (1:25) resultava em maiores índices fagocitose. Kampen et al. (2004) usaram metodologia semelhante, porém identificaram os neutrófilos usando o marcador $\mathrm{CH} 138$.

Hammon et al. (2006) avaliaram a associação entre desordens uterinas, status energético e função dos PMN do sangue em 83 vacas Holandesas multíparas, entre as semanas -1 a $8^{\circ}$ pós-parto. As vacas que desenvolveram desordens uterinas no pós-parto apresentaram maiores valores de ácidos graxos não esterificados e menor consumo de matéria seca nas semanas que antecederam o parto. Em seguida, apresentaram diminuição da atividade dos PMN no periparto antes da detecção das alterações uterinas. 
2.2.3 Função dos neutrófilos PMN da Glândula Mamária no Periparto

A primeira linha de defesa imunológica da GM dos bovinos é determinada principalmente pela quantidade e funcionalidade dos PMN residentes e recrutados do sangue (RAINARD; RIOLLET, 2006). As células residentes da glândula mamária são poucas e têm baixa funcionalidade, podendo ser a causa da maior incidência e severidade das manifestações clínicas diante de processo infeccioso. No entanto, essas células podem ser a chave para a defesa imunológica do úbere, induzindo a migração de células jovens para a glândula mamária (MEHRZAD; DUCHATEAU; BURVENICH, 2004).

Nos processos infecciosos da GM, a atividade celular é regulada pelas citocinas pró-inflamatórias, que aumentam a capacidade bactericida dos neutrófilos e macrófagos, promove o recrutamento dos neutrófilos para o local da infecção, induz a maturação de células dendríticas e modula a resposta imune adquirida (ALLUWAIMI; CULLOR, 2002; HORNEF et al., 2002).

Uma grande variedade de citocinas, como as interleucinas (IL1, IL-6), interferon gama (INF-y) e fator de necrose tumoral alpha (TNF- $\alpha$ ) têm sido encontrados no colostro e leite provenientes de GM saudáveis e infectadas (Sordillo; Streicher, 2002) (ALLUWAIMI, 2004; MADUREIRA, 2012). Estudos demonstraram que a IL-1, IL-6 e TNF estão associadas com o aumento de neutrófilos na GM (DALEY et al., 1991; BARBOSA LIMA, 2014). Vacas com mastite apresentam valores elevados de IL-6 no leite (SHUSTER et al., 1997). Além disso, estudos demonstraram que o tratamento in-vitro de células PMN com IFN- $\gamma$, mostraram aumento significativo a capacidade funcional dessas células contra Staphylcococcus aureus (SORDILLO; BABIUK, 1991).

A migração dos neutrófilos PMN através da diapedese do sangue ao epitélio mamário resulta em diminuição da capacidade fagocítica e atividade oxidativa dessas células (SCHALM; LASMANIS; CARROLL, 1964). Além disso, ao alcançar a glândula mamária, os PMN ingerem grande quantidade de gordura e caseína, intensificando a redução da capacidade fagocítica (PAAPE E GUIDRY, 1977). Este fenômeno está associado à meia vida curta dos PMN na secreção mamária, ao 
redor de 8 horas, devido à exaustão da sua reserva de glicogênio intracelular resulta em redução do burst respiratório e induz a apoptose (MEHRZAD et al., 2001).

A avaliação dos neutrófilos PMN na secreção mamária é fundamental, especialmente no pós-parto imediato, considerando-se as altas taxas de infecção mamária. No entanto, a presença abundante de debris celulares, gordura, proteínas e partículas auto-fluorescentes prejudica a obtenção das células do colostro para avaliação da sua atividade funcional (ONTSOUKA; BRUCKMAIER; BLUM, 2003; PIEPERS; DE VLIECHER; DEMEYER, 2009; MEGANCK et al., 2014; GOMES et al., $2014^{2}$ no prelo).

A pequena proporção de neutrófilos $\mathrm{PMN}$ do colostro de $1^{\circ}$ ordenha (8 a 12\%) dentre os demais componentes celulares e debris foi relatado por Gomes et al. (2014 no prelo) $)^{2}$. Fato semelhante foi encontrado por Meganck et al. (2014) que investigaram a atividade funcional dos linfócitos do colostro bovino. Desta forma, a maioria dos trabalhos apresenta resultados a partir do $3^{\circ}$ dia pós-parto.

Em quartos mamários saudáveis a CCS (contagem de células somáticas) é de $0,8 \times 10^{6}$ células $/ \mathrm{mL}$ de colostro, dessas aproximadamente 3 a $20 \%$ são $P M N$ (CONCHA; HOLMBERG; ASTROM, 1986; LEE; WOODING; KEMP, 1980; MILLER; PAAPE; FULTON, 1991; SORDILLO; SHAFER-WEAKER; DEROSA, 1997), porém, o tipo celular predominantemente encontrado é o macrófago (GOMES et al., 2011).

A viabilidade das células totais do colostro bovino é de aproximadamente $30 \%$ (GODDEN et al., 2012). Piepers; De Vliecher; Demeyer (2009) estudaram amostras de leite de transição com baixa e alta celularidade, a partir do $3^{\circ}$ dia pós-parto e encontraram viabilidade de 10,5 a $85 \%$.

Mehrzad et al. (2001) encontraram CCS de 0,65; 0,47; e 0,44 x $10^{6}$ células $/ \mathrm{mL}$ de leite, respectivamente, utilizando vacas Holandesas entre o $3^{\circ}$ ao $11^{\circ}, 12^{\circ}$ ao $20^{\circ}$, e $21^{\circ}$ ao $30^{\circ}$ dias pós-parto. Observaram menor proporção de PMN no primeiro período de estudo (26\%) em relação aos valores de $39-40 \%$ observado nos momentos subsequentes. A viabilidade dos PMN também foi menor entre $\circ 3^{\circ}$ ao $11^{\circ}(27 \%)$ em relação às demais semanas (42 e 49\%).

\footnotetext{
${ }^{2}$ GOMES, V.; MADUREIRA, K. M.; SORIANO, S.; PONTES, G. N.; SILVA, B. T.; BENESI, F. J. Release of hydrogen peroxide by phagocytes from bovine colostrum in the peripartum period. Acta Veterinaria Brno, 2014.
} 
No leite de vacas em lactação foi observada viabilidade de PMN para $63 \%$ obtido de quartos mamários sadios e 93\% após inoculação experimental com patógenos bacterianos (MEHRZAD; DUCHATEAU; BURVENICH, 2004).

A redução na atividade funcional dos neutrófilos $P M N$ no período de transição no sangue e leite tem sido associada à alta incidência de mastite no pós-parto imediato. Pesquisas demonstraram que a diminuição nos índices de fagocitose e geração de EROs no pós-parto é mais marcante nos PMN do leite quando comparados aos encontrados no sangue (MEHRZAD et al., 2001, 2002).

Mehrzad et al. (2001) avaliou a influência da fase da lactação sobre a viabilidade e burst respiratório de PMN no sangue e leite de vacas Holandesas em diferentes estágios de lactação. Para tanto, selecionou vacas saudáveis e livres de mastite $(n=30)$ no início - 3 a 20 dias pós-parto; meio - 150 a 210 dias pós-parto; e final da lactação - 220 a 300 dias pós-parto. O burst respiratório dos PMN, estimulados ou não com PMA (acetato de forbol miristato), e sua viabilidade no sangue e leite avaliados por quimiluminescência $(C L)$, foi significativamente menor no início da lactação em relação aos demais períodos. Neutrófilos sanguíneos apresentaram maior atividade funcional quando comparadas aos PMN obtidos a partir da secreção mamária.

A segunda pesquisa de Mehrzad et al. (2001) avaliou longitudinalmente 12 vacas Holandesas, obtendo amostras em três intervalos distintos: de 3-11 dias, 1220 dias e 21-30 dias pós-parto. O burst respiratório dos PMN, estimulados ou não com PMA, e sua viabilidade foram significativamente menores durante os dias 3-11 pós-parto em relação aos demais períodos. Os autores acreditam que altas concentrações de corpos cetônicos e corticóides, associados às oscilações hormonais do período são responsáveis pela menor atividade funcional dos PMN. A quimiluminescência dos PMN do sangue foi maior que as encontradas com as células da secreção mamária. Nos dois estudos de Mehrzad et al. (2001), os PMN não estimulados apresentaram maior quimiluminescência que neutrófilos estimulados com PMA.

Mehrzad et al. (2002) avaliaram o efeito do número de partos na atividade funcional de neutrófilos no leite e sangue de vacas Holandesas no periparto, sem infecção mamária e outras doenças da produção. Estes autores observaram maior viabilidade e quimiluminescência nos PMN do sangue em relação ao leite; maior 
atividade funcional em primíparas que nas vacas multíparas. Os dois grupos de vacas apresentaram mínima quimiluminescência na primeira semana pós-parto, especialmente entre o $2^{\circ}$ e $3^{\circ}$ dia pós-parto.

Mehrzad; Duchateau; Burvenich (2004) estudaram a interação patógenohospedeiro durante mastite induzida pela inoculação de Escherichia coli nos quartos esquerdo de vacas Holandesas no $20^{\circ}$ dia $( \pm 5 \mathrm{~d})$ após a parição. Verificaram que a quimiluminescência dos PMN na secreção mamária de vacas infectadas aumentou mais rapidamente que aqueles do sangue ou leite de vacas não-infectadas. $O$ pico máximo da quimiluminescência dos PMN ocorreu nas 12 horas após a infecção com Escherichia coli, tanto para os PMN estimulados com PMA, látex e sem estímulo. No sangue, o pico observado para os PMN estimulados ou não ocorreu no período de 48 a 72 horas pós-infecção.

A viabilidade dos PMN do leite antes da infecção com Escherichia coli foi $63 \%$ aumentando para $86,93,89$ e $76 \%$, respectivamente, às $6,12,18-24,48-72 \mathrm{~h}$ pósinfecção, observando retorno aos valores basais nos momentos subsequentes. A viabilidade dos PMN isolados dos quartos sadios contralaterais aumentou de 63,5 para $77 \%$ após $6 \mathrm{~h}$ da infecção, retornando aos valores basais nos períodos posteriores, concluindo que a sobrevivência dos PMN recrutados para os quartos infectados foi maior do que aqueles provenientes de quartos não infectados. Observaram ainda correlação negativa e forte entre a viabilidade dos PMN no leite com a inibição do crescimento bacteriano nas 6 horas pós-infecção; relação inversa entre a viabilidade dos PMN do leite e perda da produção diária de leite nas 48 horas após a infecção; e correlação positiva entre a viabilidade dos PMN e quimiluminescência (MEHRZAD; DUCHATEAU; BURVENICH, 2004).

Rivas; Tadevosyan; Gorewit (2006) avaliaram a atividade fagocítica de neutrófilos e macrófagos no leite em vacas sem infecção mamária com alta $(\geq 200.000)$ e baixa celularidade ( $<200.000$ ). Neutrófilos e macrófagos apresentaram duas populações com baixa e alta atividade de fagocitose, concluindo que a alta celularidade estava associada com baixa atividade celular.

Mehrzad; Duchateau; Burvenich (2009) examinaram o efeito da parição sobre a viabilidade e atividade funcional de neutrófilos polimorfonucleares isolados do sangue e leite contra Staphylococcus aureus em vacas Holandesas primírapas $(n=6)$ e multíparas $(n=6)$ durante 0 início da lactação (até 30 dias após o parto). A 
fagocitose de Staphylococcus aureus pelos PMN foi significativamente maior no sangue $(53 \%$ - primíparas e $30 \%$ - multíparas) quando comparada àquela obtida com as células lácteas (30\% - primíparas e $20 \%$ - multíparas). A proporção (\%) de bactérias mortas foi significativamente maior nos PMN do sangue $(42,3 \%$ primíparas e $23,2 \%$ - multíparas) que leite (20,7\% - primíparas e 10,2\% em multíparas). A fagocitose e atividade microbicida foram maiores no sangue e leite das primíparas.

A viabilidade dos PMN do sangue de primíparas e multíparas foram semelhantes (99 e 98\%), porém os índices sanguíneos foram maiores que àqueles observados no leite (71\% - multíparas e $49 \%$ - primíparas). A quimiluminescência dos PMN estimulados com látex, observando maior produção de radicais livres nos $P M N$ do sangue e leite nas vacas primíparas em relação às multíparas (MEHRZAD; DUCHATEAU; BURVENICH, 2009).

Com base na literatura apresentada, observou-se maior CCS no leite, menor viabilidade e atividade funcional dos neutrófilos lácteos, especialmente em vacas multíparas nos primeiros dias pós-parto. Diferença na qualidade da resposta imune inata entre os PMN do sangue e secreção mamária é marcante. A resposta diante da exposição experimental in vitro ou in vivo para Escherichia coli ou Staphylococcus aureus no início da lactação resultou em aumento da CCS, viabilidade e produção de radicais livres pelos PMN.

A maioria dos dados apresentados foi gerado por um grupo de pesquisa da "Guent University" orientados pelo Prof. Dr. Burvenich, que apesar da vasta experiência na área, não apresentaram dados sobre a função dos PMN do colostro bovino. 


\section{MATERIAL E MÉTODOS}

\subsection{ETAPA DE TRIAGEM}

Esta pesquisa foi realizada na Agência Paulista de Tecnologia dos Agronegócios (APTA) - Gado de leite, localizada na cidade de Nova Odessa. Nesta etapa foram selecionadas 13 vacas gestantes, da raça Holandesa preta e branca, de $2^{\circ}$ a $4^{\circ}$ parição, com partos previstos para 25/10/2013.

Para o estabelecimento do status de higidez do aparelho mamário das vacas previamente selecionadas, foi realizado o exame específico da GM (ROSENBERGER et al., 1993), associado a três exames bacteriológicos em dias consecutivos, na semana que antecedeu o início da fase experimental (semana -4 do parto previsto). O status de higidez do aparelho mamário pode ser observado nos apêndices A e B. 


\subsection{ETAPA EXPERIMENTAL}

Durante o período pré-parto, as vacas foram mantidas em piquete maternidade até sua parição. Em seguida foram transferidas para o piquete de recém-paridas (Figura 01).

Figura 1 - Piquetes onde as vacas foram mantidas no período pré $(A / B)$ e pós-parto $(C)$ São Paulo - 2013

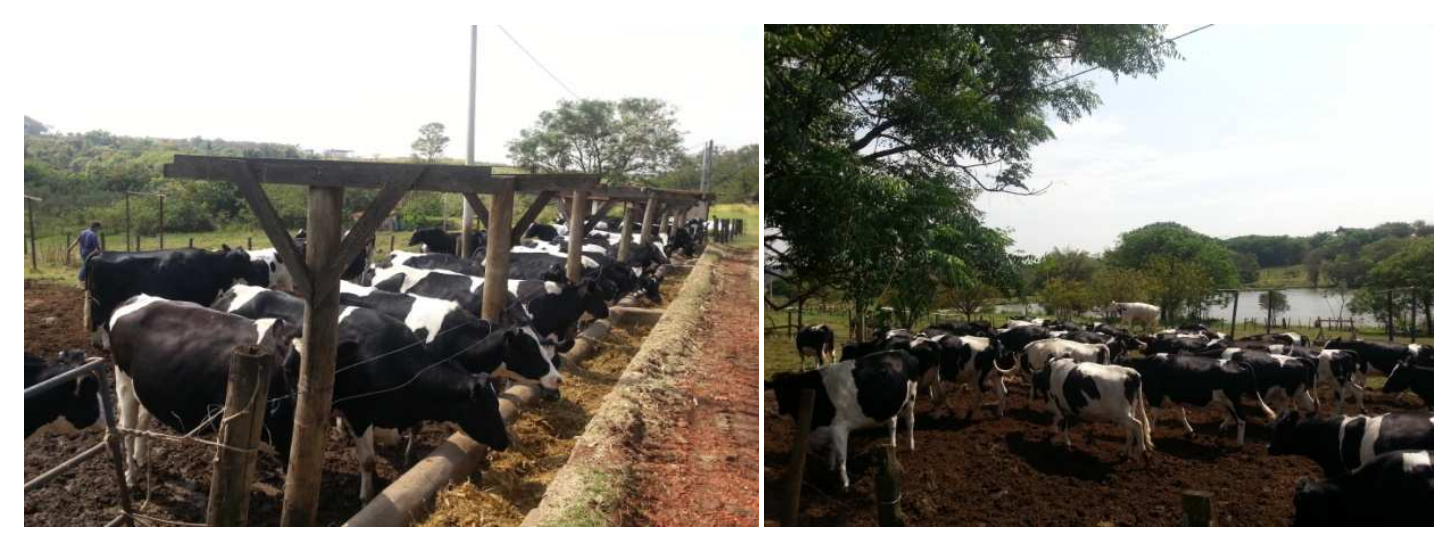

A

B

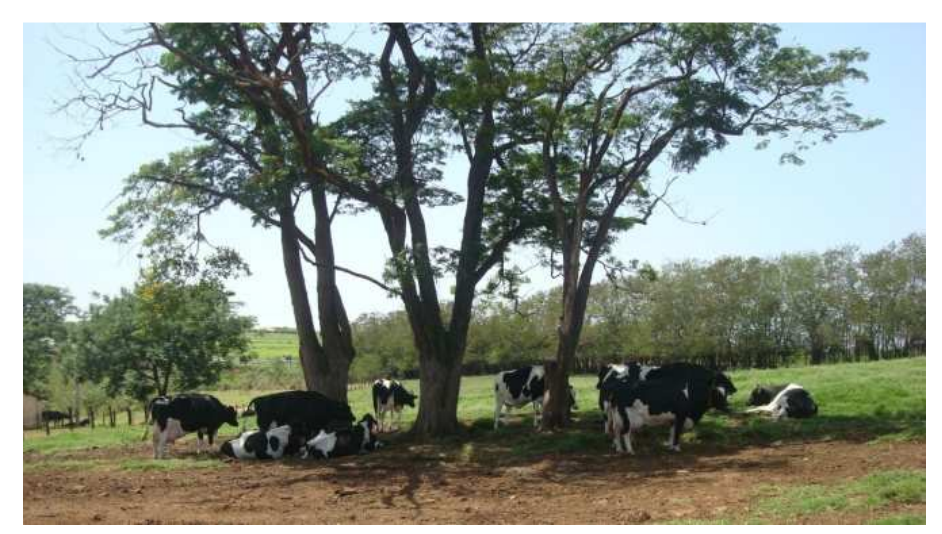

C

Fonte: (SILVA, C. P. C., 2013). 


\subsubsection{Período de Avaliação}

As vacas $(n=13)$ foram acompanhadas durante o período de transição, realizando-se avaliações entre o $21^{\circ}$ dia pré-parto ao $21^{\circ}$ dia pós-parto: semanas -3 , -2 e -1 pré-parto; na parição; e nas semanas 1, 2 e 3 pós-parto.

As avaliações dos parâmetros sanguíneos, exame específico da GM e bacteriológico da secreção mamária foram realizados da semana $-3 a+3$. As demais provas para avaliação da secreção mamária (SM) foram iniciadas a partir da data da parição (Quadro 1).

Durante o período experimental, o exame da GM e colheita de sangue foram realizados em tronco de contenção (Figura 2). Em seguida, as vacas foram encaminhadas para a sala de ordenha para higienização dos tetos e colheita das amostras para o exame bacteriológico. A partir da parição, iniciaram-se as análises macroscópicas e colheitas das amostras da secreção mamária, também obtidas na sala de ordenha, para avaliação da resposta imune inata (Figura 3).

Quadro 1 - Cronologia das avaliações realizadas no sangue e secreção mamária (SM) de Holandesas no período de transição - São Paulo - 2013

\begin{tabular}{|c|c|c|c|c|c|}
\hline Momentos & Exame da GM & $\begin{array}{c}\text { Micro } \\
\text { SM }\end{array}$ & RI - Sangue & CCS e FE & RI - SM \\
\hline M-3 & $\checkmark$ & $\checkmark$ & $\checkmark$ & & \\
\hline M-2 & $\checkmark$ & $\checkmark$ & $\checkmark$ & & \\
\hline M-1 & $\checkmark$ & $\checkmark$ & $\checkmark$ & $\checkmark$ & \\
\hline M0 & $\checkmark$ & $\checkmark$ & $\checkmark$ & $\checkmark$ & $\checkmark$ \\
\hline M1 & $\checkmark$ & $\checkmark$ & $\checkmark$ & $\checkmark$ & $\checkmark$ \\
\hline M2 & $\checkmark$ & $\checkmark$ & $\checkmark$ & $\checkmark$ & $\checkmark$ \\
\hline M3 & $\checkmark$ & $\checkmark$ & $\checkmark$ & & $\checkmark$ \\
\hline
\end{tabular}

Legenda: CCS - contagem de células somáticas; Micro - Microbiológico; RI - Resposta Imune; FE - Fundo escuro

Fonte: (SILVA, C. P. C., 2013) 
Figura 2- Tronco de contenção onde foram realizados exame específico do aparelho mamário e colheita de amostras, exceto as alíquotas destinadas ao exame bacteriológico e separação dos fagócitos - São Paulo - 2013
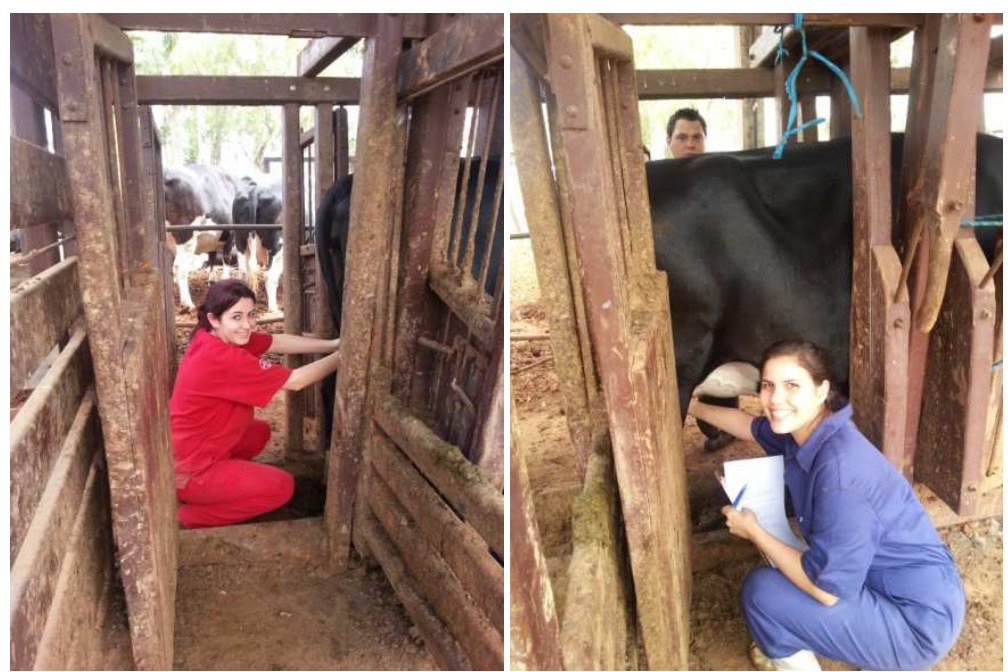

Fonte: (SILVA, C. P. C., 2013)

Figura 3 - Sala de ordenha onde foram colhidas as alíquotas destinadas ao exame bacteriológico e obtenção dos fagócitos da secreção mamária - São Paulo - 2013

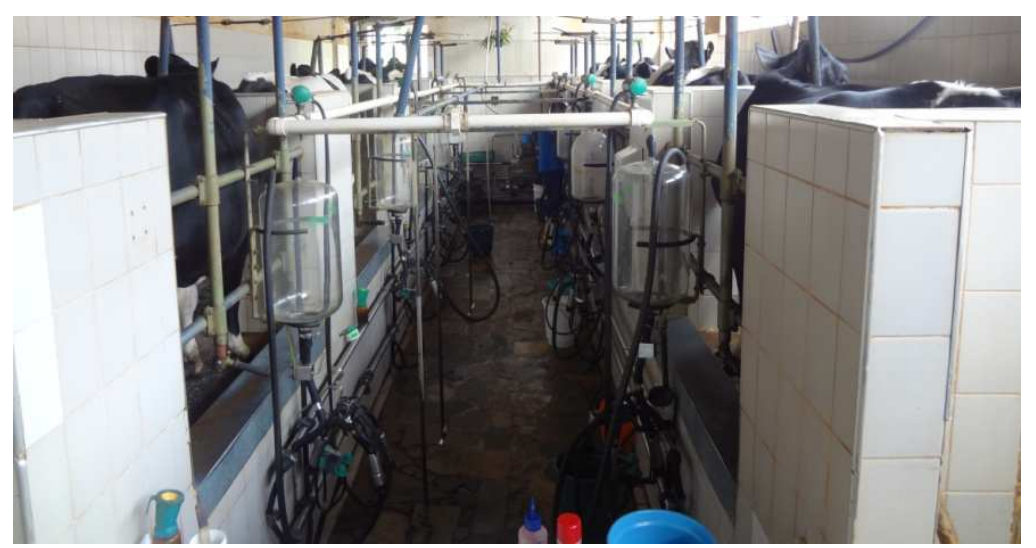

Fonte: (SILVA, C. P. C., 2013) 
3.2.2 Exame específico da glândula mamária

A metodologia empregada nesta pesquisa seguiu os procedimentos recomendados por Rosenberger (1993). O exame específico da glândula mamária foi realizado no período da tarde (13:00 horas), por meio das técnicas semiológicas de inspeção e palpação da mama e linfonodos retromamários (Figuras 4 e 5). Os parâmetros e quesitos adotados estão dispostos no quadro 2.Quadro 1

Quadro 1- Parâmetros e quesitos adotados no exame específico da GM - São Paulo - 2013

\begin{tabular}{|l|l|l|}
\hline Variáveis & Parâmetros & Quesitos \\
\hline \multirow{4}{*}{ Inspeção } & Aumento do Volume Generalizado & $\begin{array}{l}\text { Ausente } \\
\text { Presente }\end{array}$ \\
\cline { 2 - 3 } & Aumento de Volume Localizado & $\begin{array}{l}\text { Ausente } \\
\text { Presente }\end{array}$ \\
\cline { 2 - 3 } & Assimetria & $\begin{array}{l}\text { Ausente } \\
\text { Presente }\end{array}$ \\
\cline { 2 - 3 } & Coloração & $\begin{array}{l}\text { Normal } \\
\text { Avermelhada } \\
\text { Arroxeada }\end{array}$ \\
\hline \multirow{4}{*}{ Palpação } & Elasticidade & $\begin{array}{l}\text { Normal } \\
\text { Diminuída }\end{array}$ \\
\cline { 2 - 3 } & Aumento de temperatura & $\begin{array}{l}\text { Não } \\
\text { Sim }\end{array}$ \\
\cline { 2 - 3 } & Consistência & $\begin{array}{l}\text { Macia e sem nódulos } \\
\text { Endurecida }\end{array}$ \\
& & Edemaciada \\
\hline \multirow{2}{*}{$\begin{array}{l}\text { Linfonodos } \\
\text { retromamários }\end{array}$} & Volume & Normal \\
& & Um linfonodo aumentado \\
& & Dois linfonodos aumentados \\
\hline
\end{tabular}

Fonte: (SILVA, C. P. C., 2013) 
Figura 4 - Avaliação da GM pela técnica de inspeção: (A) vista posterior; (B) vista lateral direita; (C) vista lateral esquerda de aparelho mamário considerado simétrico; (D) vista posterior; $(E)$ vista lateral direita; $(F)$ vista lateral esquerda de GM assimétrica - São Paulo - 2013

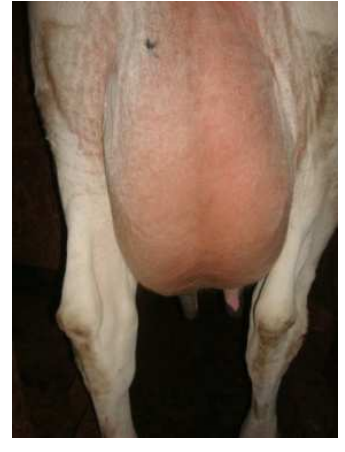

(A)

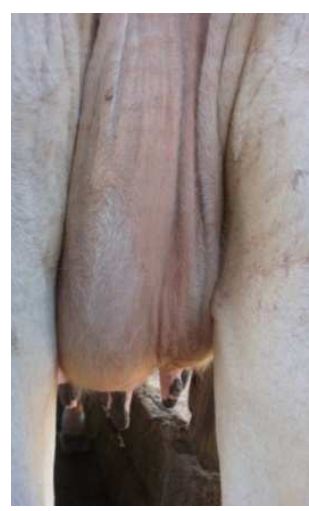

(D)

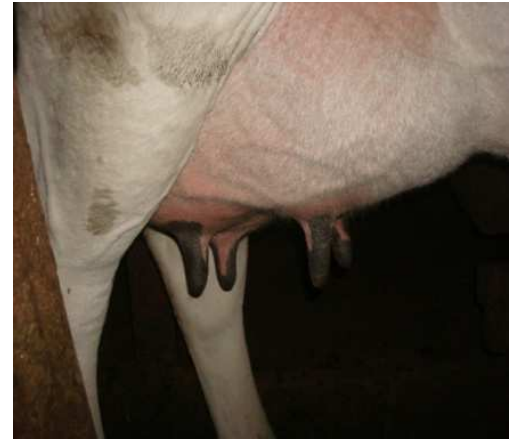

(B)

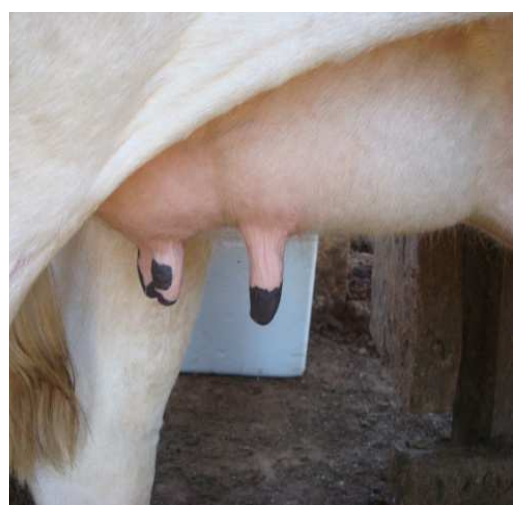

(E)

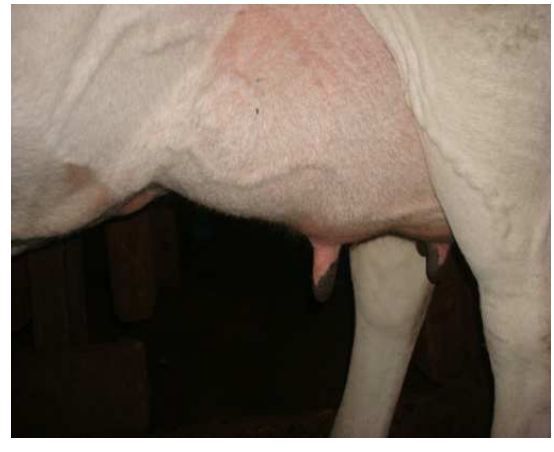

(C)

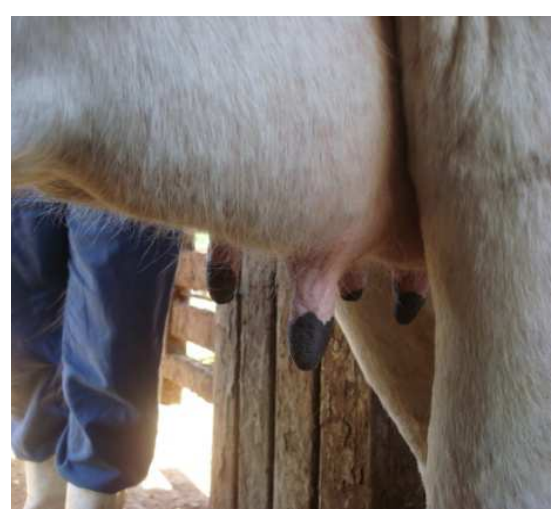

$(\mathrm{F})$

Fonte: (SILVA, C. P. C., 2013) 
Figura 5 - Avaliação da GM pela técnica de palpação: (A) palpação do parênquima mamário; (B) palpação dos linfonodos retromamários - São Paulo - 2013

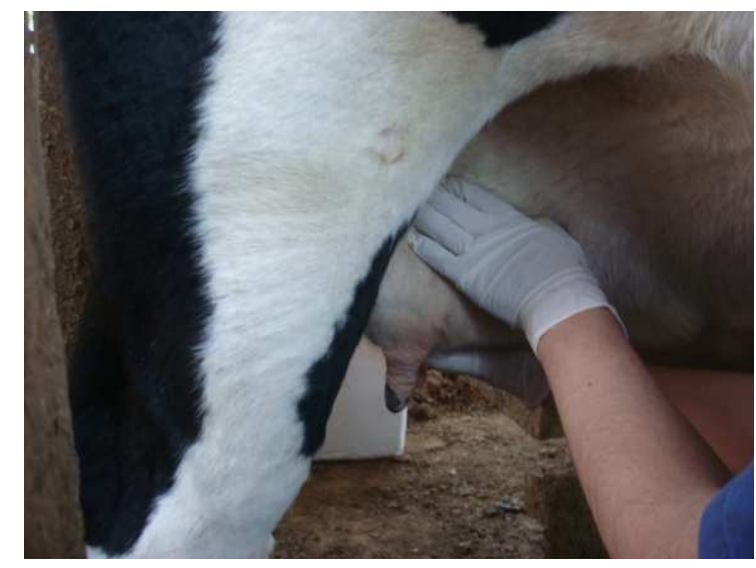

(A)

Fonte: (SILVA, C. P. C., 2013)

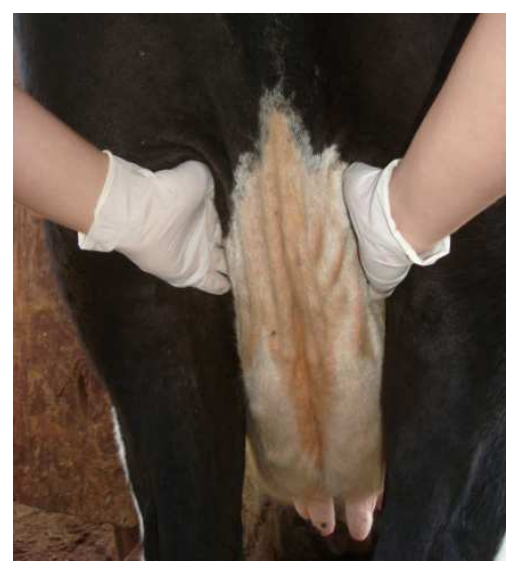

(B)

\subsubsection{Colheita de amostras}

As vacas foram encaminhadas para a sala de ordenha e higienizadas pela lavagem dos tetos com solução de hipoclorito de sódio a $2 \%$, seguida de secagem dos tetos individualmente com papel toalha. Inicialmente, foi realizado o teste de FE para análise macroscópica e eliminação dos primeiros jatos de leite, em seguida, foram colhidas três alíquotas da secreção mamária.

Para a colheita da primeira alíquota destinada ao exame bacteriológico em frascos plásticos estéreis com tampa de rosca ( $3 \mathrm{~mL})$, foi realizada a antissepsia dos tetos pela fricção de algodão com álcool $70 \%$ em sua abertura. Posteriormente, foi obtida a segunda alíquota para a CCS microscópica e mensuração citocina IFN- $\gamma$ em frascos cônicos plásticos $(50 \mathrm{~mL})$. Por fim, realizou-se a colheita de $1 \mathrm{~L}$ de secreção mamária diluída em PBS (Phosphate Buffered Saline) na proporção 1:1 (Anexo A), para a composição da terceira alíquota e obtenção dos leucócitos viáveis do colostro e leite.

Para as análises sanguíneas, amostras foram obtidas em tubos contendo EDTA (Ethylenediamine tetraacetic acid), heparina sódica e sem anticoagulante, por punção da veia coccígea, através de sistema a vácuo, após antissepsia com álcool $70 \%$. 


\subsection{ETAPA LABORATORIAL}

\subsubsection{Exame Bacteriológico}

As amostras obtidas para o exame bacteriológico foram semeadas em placas de Petri contento meio de ágar-sangue de carneiro $(5 \%)$. As placas foram incubadas em estufa bacteriológica a $37^{\circ} \mathrm{C}$, realizando leituras às 24,48 e 72 horas. Foram consideradas como positivas, as amostras que apresentaram isolamento de três ou mais colônias do mesmo gênero de microrganismo. Para o Staphylococcus coagulase-positiva considerou-se positivas aquelas que apresentaram isolamento de $\geq 1$ colônia bacteriana (NATIONAL MASTITIS COUNCIL, 1999).

A identificação das bactérias foi realizada pelas suas características morfológicas e tintoriais, seguida pela prova de catalase e coagulase. As bactérias Gram-negativas foram identificadas por meio de provas bioquímicas (LENETTE; BALOWS; HANSLER, 1985), seguida da classificação estabelecida por Krieg; Holt (1994) e Murray et al. (1999).

\subsubsection{Contagem de Células Somáticas}

A contagem de células somáticas do colostro e leite foi realizada utilizando-se a técnica da contagem microscópica direta, seguindo os procedimentos descritos por Gomes et al. (2011). Inicialmente o colostro diluído em PBS (1:1) e leite puro (10 $\mu \mathrm{L})$, foram distribuídos em uma área de $1 \mathrm{~cm}^{2}$ em lâmina microscopia, mantidas por 24 horas em temperatura ambiente para secagem. As lâminas foram coradas pela técnica de Rosenfeld e avaliadas pela contagem do número de células em 100 campos microscópicos, utilizando-se microscópio óptico comum com objetiva de imersão (1000X). O resultado da contagem foi multiplicado pelo fator do microscópio (fator=3571), obtendo-se o número de células somáticas $/ \mathrm{mL}$ de leite. No caso do 
colostro, houve ainda a necessidade de multiplicar o resultado final por dois, em função da diluição inicial da alíquota.

\subsubsection{Leucograma}

O número total dos leucócitos sanguíneos foi determinado através da contagem automática no aparelho $A B C$ Vet - $A B X^{\circledR}$

\subsubsection{Obtenção dos leucócitos do colostro}

Nesta etapa de obtenção das células do colostro (M0) houve problemas com a centrífuga refrigerada rotineiramente usada nesta pesquisa. $O$ processamento das amostras em outro equipamento resultou na morte de $100 \%$ das células do colostro de quatro animais, optando-se por não continuar as colheitas pareadas das amostras de leite nos momentos M1 a M3. Desta forma, as análises da função dos neutrófilos da secreção mamária foram realizadas em nove animais.

\subsubsection{Obtenção dos leucócitos totais}

Foi colhido um litro de colostro de primeira ordenha de cada quarto mamário diluído na proporção 1:1 em PBS (Figura 6a), transportado em caixas isotérmicas contendo gelo triturado.

No laboratório, o colostro diluído de cada quarto mamário (2L) foi transferido para duas garrafas plásticas ${ }^{3}$ (Figura 6 b) específicas para centrifugação refrigerada

\footnotetext{
${ }^{3}$ Nalgene ${ }^{\circledR}$. Garrafas de Copolímero de polipropileno $1000 \mathrm{~mL}$ - Cód Produto NAL00335 - Id. do Produto 3120-1000.
} 
em equipamento de alta capacidade ${ }^{4}$. Para separação das células do colostro padronizou-se as centrifugações do processo de lavagem em $655 \mathrm{xg}$ por 15 minutos, a $4^{\circ} \mathrm{C}$, brake 5 . A centrifugação permitiu a separação do colostro em três camadas, descartando-se delicadamente as camadas superiores de gordura e fração fluída. $O$ pellet celular foi preservado nas garrafas de $1 \mathrm{~L}$, dissolvido em $25 \mathrm{~mL}$ de PBS gelado (Figura 6c), ajustando-se o volume final da suspensão celular para $500 \mathrm{~mL}$ (Figura $6 d)$.

A suspensão celular foi novamente submetida à centrifugação. $O$ pellet celular foi ressuspendido em $40 \mathrm{~mL}$ de PBS (Figura 6e), transferidos para tubos plásticos cônicos de $50 \mathrm{~mL}$ (Figura 6f), centrifugados em centrífuga refrigerada com rotor apropriado $^{5}$. O pellet celular contido em cada frasco foi ressuspenso em $10 \mathrm{~mL}$ de PBS (Figura 6g), misturando-se as suspensões celulares semelhantes, obtidas a partir de cada quarto mamário, ajustando o volume final para $30 \mathrm{~mL}$ (Figura h). $\mathrm{O}$ processo de centrifugação foi repetido $1 \mathrm{x}$.

A viabilidade das células totais do colostro foi realizada pela prova de exclusão do azul de Tripan.

\footnotetext{
${ }^{4}$ Sorvall $^{\circledR}$ - Centrífuga Refrigerada RC-3B.

${ }^{5}$ Eppendorf ${ }^{\circledR}$ Centrifuge 5810R
} 
Figura 6 - Obtenção de uma suspensão celular concentrada a partir de $1 \mathrm{~L}$ de colostro bovino. (a) um litro de colostro diluído em PBS (1:1); (b) - A solução colostro + PBS foi transferida para frascos específicos para centrifugação, em destaque é possível observar o pellet celular após o processo de centrifugação; (c) Ressuspensão do pellet em PBS; (d) Em destaque está o pellet celular, após centrifugação; (e) Ressuspensão de pellet celular em PBS; (f) Transferência do pellet ressuspenso para tubos cônicos; (g) Pellet celular obtido após centrifugação, e ressuspendido em $10 \mathrm{~mL}$ de PBS; (h) Suspensão celular concentrada - São Paulo - 2013

(a)
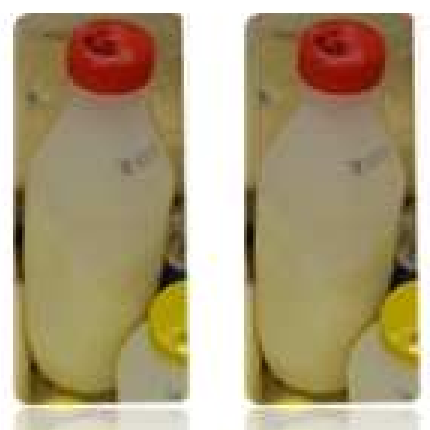

$25 \mathrm{~mL}+500 \mathrm{mLPBS}$

$25 \mathrm{~mL}+500 \mathrm{mLPBS}$

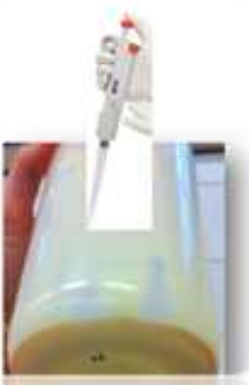

(c)

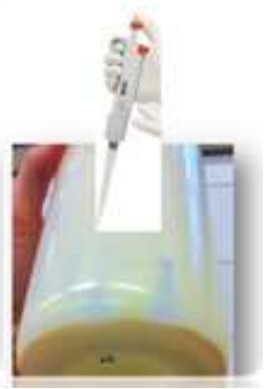

(e)

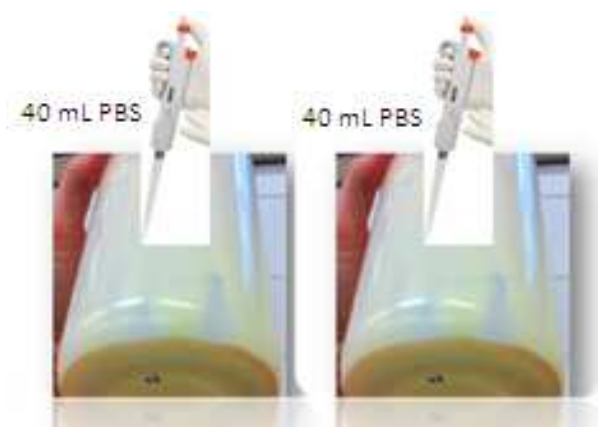

(g)

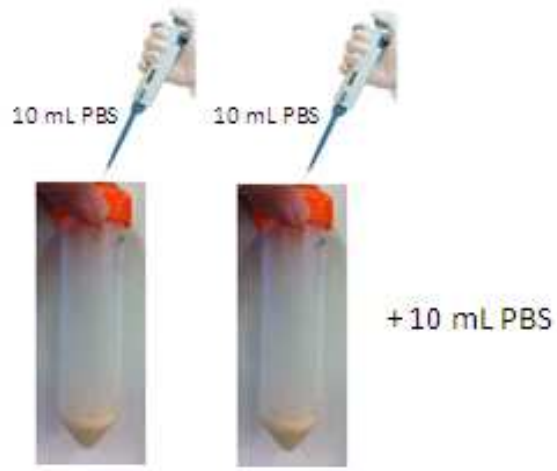

(b)
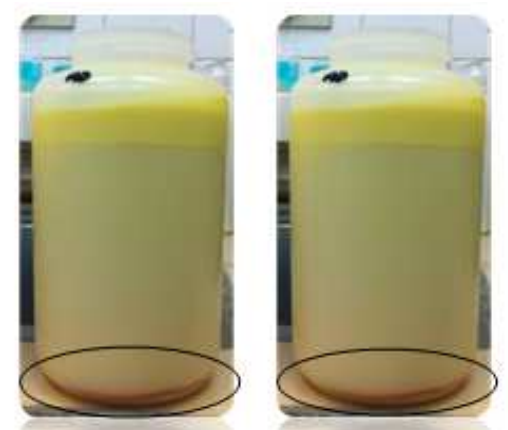

(d)
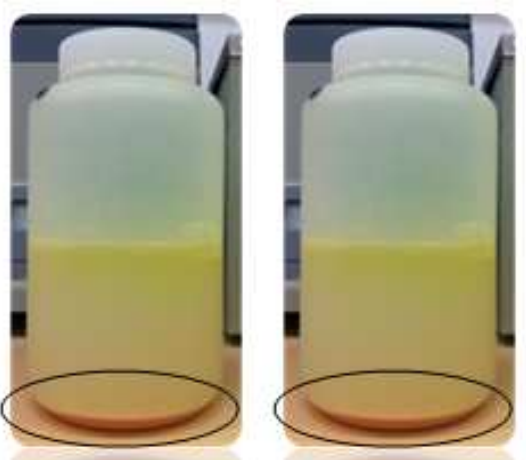

(f)
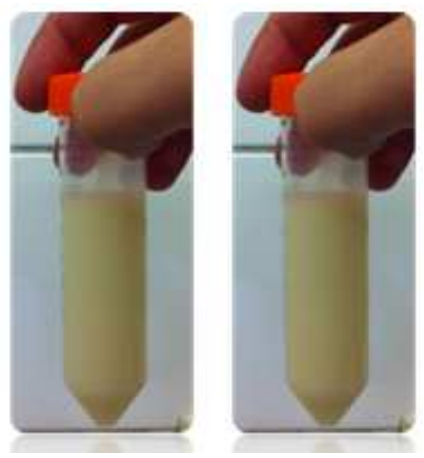

(h)

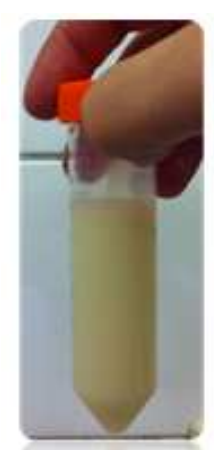

Fonte: (SILVA, C. P. C., 2013) 


\subsubsection{Determinação da viabilidade celular}

Para a avaliação da viabilidade celular, $10 \mu \mathrm{L}$ da suspensão celular

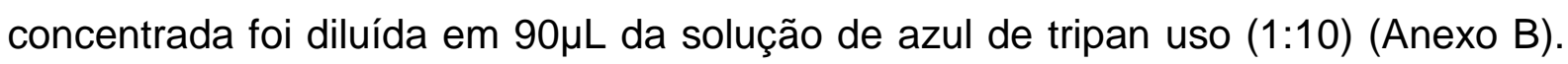
Foi adicionado $10 \mu \mathrm{L}$ da mistura à Câmara de Neubauer, contando-se as células as células translúcidas (vivas) e impregnadas de azul (mortas) em um retículo específico para a contagem de leucócitos (Figura 7). A viabilidade celular (\%) foi calculada pela divisão do número de células vivas/total de leucócitos contados.

$\%$ viabilidade $=n^{\circ}$ células vivas $\div n^{\circ}$ células mortas

A concentração de células vivas da suspensão celular foi determinada multiplicando-se o número de células viáveis contadas em um reticulado de leucócitos x diluição do azul de Tripan (10) x fator de correção da câmara de Neubauer $\left(10^{4}\right)$.

Figura 7 - Avaliação da viabilidade celular pela prova de exclusão de Azul de tripan. Secreção mamária apresentando viabilidade alta $(A)$ e viabilidade baixa (B) em vacas Holandesas - São Paulo - 2013

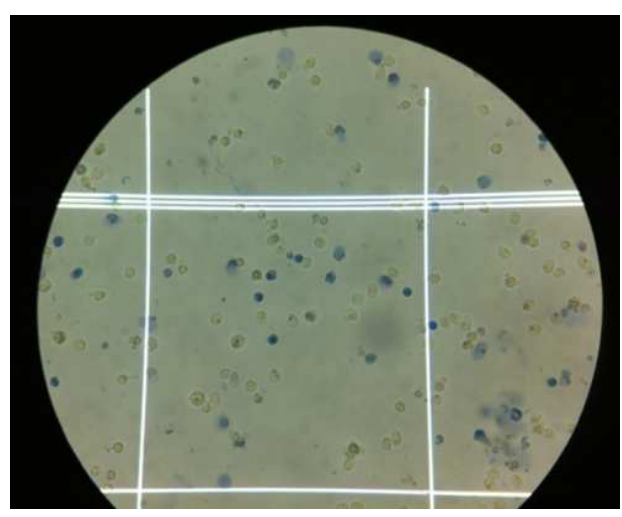

(A)

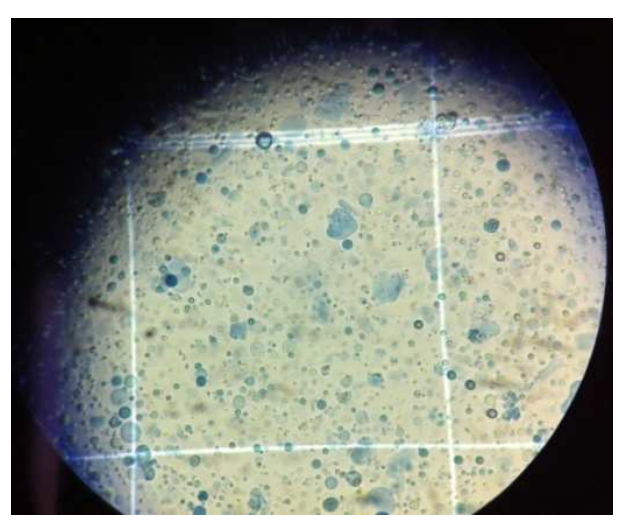

(B)

Fonte: (SILVA, C. P. C., 2013) 


\subsubsection{Separação dos neutrófilos PMN}

A separação dos PMN a partir da suspensão de células totais do colostro foi realizada em duas etapas por gradiente de densidade. Inicialmente a suspensão celular $\left(30 \mathrm{~mL}\right.$ ) foi adicionada sobre $10 \mathrm{~mL}$ de Histopaque ${ }^{\circledR} 1119^{6}$, conforme técnica padronizada pelo Dr. David John Hurley (Figuras 8a e 8b), centrifugada a 800xg por 20 minutos a $4^{\circ} \mathrm{C}$, no brake. Após centrifugação, foi obtida quatro frações constituída por PBS, células viáveis, Histopaque ${ }^{\circledR} 1119$ e debris celulares (Figura 9a).

Com o auxílio de uma pipeta, a camada de células viáveis foi retirada, e transferida para tubos plásticos, ajustando-se o volume final para $30 \mathrm{~mL}$. A suspensão celular foi adicionada sobre $10 \mathrm{~mL}$ de Histopaque ${ }^{\circledR} 1083^{7}$, sendo centrifugada, conforme descrito na etapa anterior. Após a centrifugação, a mistura foi novamente separada em quatro frações: PBS, células mononucleares, Histopaque ${ }^{\circledR} 1083$ e células PMN (Figura 9b).

A camada de PMN foi reservada e lavada por centrifugação a $800 \times$ pg por 10 minutos a $25^{\circ} \mathrm{C}$, no brake. Por fim, as células PMN obtidas foram ressuspendidas em $1 \mathrm{~mL}$ de PBS, e sua viabilidade avaliada pela prova de exclusão de Azul de Tripan.

A concentração de PMN foi ajustada para $2 \times 10^{6}$ células viáveis $/ \mathrm{mL}$, e reservada para os testes de fagocitose, produção de $\mathrm{H}_{2} \mathrm{O}_{2}$ e proporção de neutrófilos.

\footnotetext{
${ }^{6}$ Sigma ${ }^{\circledR}$ Aldrich - Referência Prod. - 11191

${ }^{7}$ Sigma ${ }^{\circledR}$ Aldrich - Referência Prod. - 10831
} 
Figura 8 - Separação dos PMN do colostro: (A) Adição da suspensão de células do colostro ao Histopaque $^{\circledR}$; (B) Aspecto bifásico da suspensão celular e Histopaque ${ }^{\circledR}$ antes da centrifugação - São Paulo - 2013

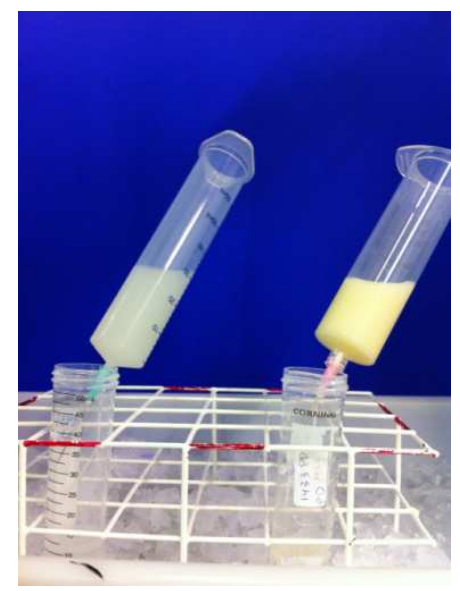

(A)

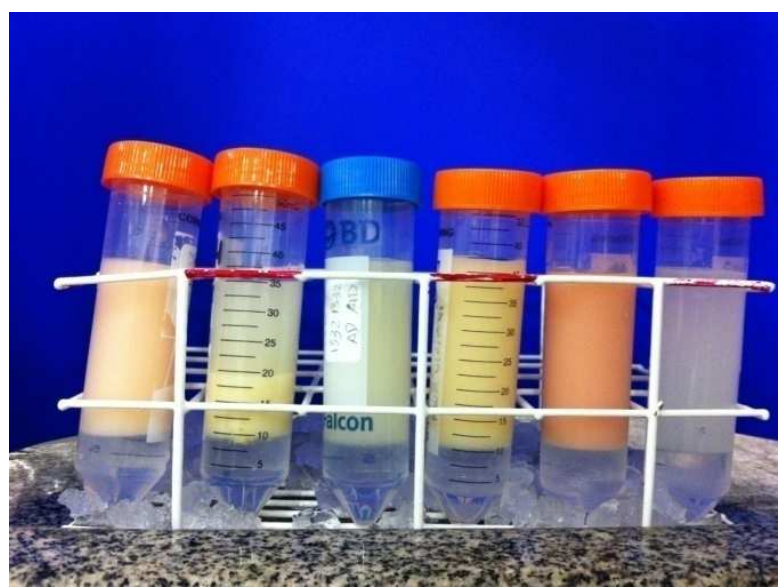

(B)

Fonte: (SILVA, C. P. C., 2013)

Figura 9 - Separação dos PMN do colostro: (a) Separação das células em camadas após $1^{\circ}$ etapa de centrifugação (Células vivas; Debris Celulares); (b) Separação das células em camadas após centrifugação com Histopaque ${ }^{\circledR} 1083$ (Células Mononucleares; PMN) - São Paulo - 2013

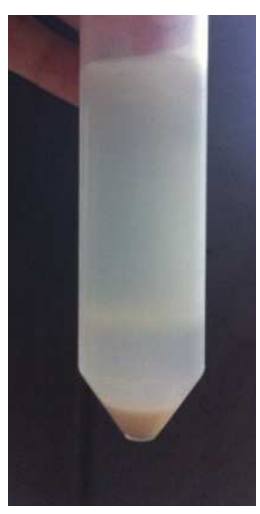

(A)

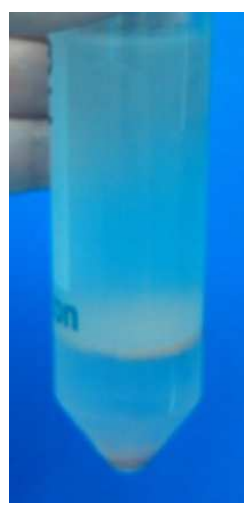

(B)

Fonte: (SILVA, C. P. C., 2013) 


\subsubsection{Obtenção dos leucócitos do leite}

Para a obtenção das células do leite, foi colhido $1 \mathrm{~L}$ de leite de cada quarto mamário, diluído em PBS gelado na proporção 1:1. As amostras foram transportadas e centrifugadas em condições semelhantes às descritas para o colostro. Inicialmente foram centrifugadas a $943 \times$ g por 15 minutos a $4^{\circ} \mathrm{C}$, brake 5 . Após este processo, o pellet celular foi ressuspendido em $15 \mathrm{~mL}$ de PBS e transferidos para tubos cônicos de $50 \mathrm{~mL}$, misturando o material obtido a partir do mesmo quarto mamário, ajustando-se o volume final para $40 \mathrm{~mL}$. A suspensão celular obtida foi lavada duas vezes por meio de centrifugação a $600 \times \mathrm{xg}$ por 15 minutos, a $4^{\circ} \mathrm{C}$, aceleração 5 e no brake. Este processo foi repetido 1x. Após a segunda centrifugação, o pellet celular foi ressuspendido em um $\mathrm{mL}$ de PBS suplementado com $10 \%$ de Soro Fetal Bovino ${ }^{8}$ (SFB). Por fim, foi realizada a avaliação da viabilidade celular e a concentração celular ajustada $2 \times 10^{6}$ células viáveis/mL, reservadas para realização dos ensaios de fagocitose, produção de $\mathrm{H}_{2} \mathrm{O}_{2}$ e proporção de neutrófilos do leite.

3.3.5 Proporção e avaliação funcional dos neutrófilos $\mathrm{CH}_{138^{+}}$do sangue e secreção mamária

Foram realizados ensaios com leucócitos sanguíneos e células extraídas da secreção mamária. Os ensaios realizados estão especificados no quadro 3.

Para realização desta prova, foram utilizadas Staphylococcus aureus e Escherichia coli isoladas do leite de vaca com mastite, gentilmente cedidas pelo Prof. Dr. Nilson Roberti Benites. As bactérias foram marcadas com iodeto de propídeo (Anexo C).

Para a realização destes ensaios, foram adicionados $100 \mu \mathrm{L}$ de sangue heparinizado ou suspensão das células da secreção mamária contendo $2 \times 10^{5}$ células em tubos de citometria de fluxo. Em seguida, foi adicionado $200 \mu \mathrm{L}$ da

\footnotetext{
${ }^{8}$ Cutilab $^{\circledR}$ - Produto estéril e inativado
} 
solução de uso do DCFH-DA ${ }^{9}$ (Anexo D), $50 \mu \mathrm{L}$ da bactéria marcada, ajustando o volume final da mistura para $1100 \mu \mathrm{L}$, utilizando PBS suplementado com SFB a $10 \%$. A mistura foi incubada em estufa a $37^{\circ} \mathrm{C}$ por 30 minutos, mantidas em suspensão com o uso de homogeneizador. Em seguida, foi adicionado $2000 \mu \mathrm{l}$ de EDTA $3 \mathrm{mM}$ gelado somente nos ensaios onde bactérias foram acrescidas. Nos ensaios realizados com sangue total, foi realizada a lise das hemácias, onde foram acrescentados $2 \mathrm{~mL}$ de $\mathrm{NaCl} 0,2 \%$ por 20 segundos e em seguida $2 \mathrm{~mL}$ de $\mathrm{NaCl}$ $1,6 \%$. O processo de lise foi realizado duas vezes, seguida de centrifugação dos ensaios a $282 \mathrm{~g}$ por 7 minutos a $4^{\circ} \mathrm{C}$., para lavagem das células $(2 \mathrm{x})$ e retirada do excesso de iodeto de propídeo.

Por fim, os tubos foram ressuspendidos em 100uL de PBS gelado para a realização da marcação das células, adicionando-se $0,25 \mu \mathrm{L}$ de anticorpo primário $\mathrm{CH} 138^{10}$. A mistura foi mantida sobre refrigeração por 30 minutos. Em seguida, os tubos foram centrifugados a $282 \times \mathrm{xg}$ por 8 minutos a $4^{\circ} \mathrm{C}$, o sobrenadante foi desprezado, adicionando-se $100 \mu \mathrm{L}$ de PBS gelado ao pellet celular para homogeneização. $\mathrm{O}$ anticorpo primário foi conjugado pela adição de $0,5 \mu \mathrm{L}$ de $\mathrm{APC}^{11}$ (Allophycocyanin), mantidos sob refrigeração por 40 minutos. Após o término das incubações, uma última centrifugação foi realizada, seguindo os procedimentos já descritos.

As células sanguíneas e da secreção mamária marcadas foram ressuspendidos em $100 \mu \mathrm{L}$ e $300 \mu \mathrm{L}$ de PBS, respectivamente. Foram adquiridos 20.000 eventos para o sangue e 40.000 eventos para a secreção mamária em citômetro de fluxo ${ }^{12}$. A análise da fluorescência emitida pelo anticorpo secundário foi realizada pelo software FlowJo ${ }^{\circledR}$, utilizando o programa CellQuest ${ }^{\circledR}$, de acordo com os procedimentos descritos nas Figuras 10 a 17.

Os resultados das proporções de neutrófilos $\mathrm{CH}_{138^{+}}$(\%) obtidos por citometria de fluxo foram transformados em valores absolutos a partir do valor de leucócitos totais obtidos no hemograma.

\footnotetext{
${ }^{9}$ Sigma $^{\circledR}$ Aldrich, St. Louis, EUA, no cat. D6883.

${ }_{11}^{10}$ Washington State University ${ }^{\circledR}$, - mouse IgM anti-bovine $\mathrm{CH} 138, \mathrm{n}^{\circ}$ cat. $\mathrm{CH} 138 \mathrm{~A}$

${ }^{11}$ Invitrogen $^{\circledR}$ - APC - goat anti-mouse IgM, no cat.M31505

${ }^{12}$ FACSCalibur Flow Cytometer (Becton Dickinson Immunocytometry System®), San Diego, CA
} 
Quadro 3 - Ensaio de fagocitose, produção de $\mathrm{H}_{2} \mathrm{O}_{2}$ e proporção (\%) de neutrófilos $\mathrm{CH} 138^{+}$do sangue e secreção mamária de vacas Holandesas - São Paulo - 2013

\begin{tabular}{llllllll}
\hline Tubo & Fluorescência & Sangue/S.M. & DCFH & BACT & PBS & CH138 & Evento \\
\hline A & Branco & S & - & - & S & - & Branco \\
B & FL1 & S & S & - & S & S & Burst Basal \\
C & FL2 & S & - & Sapi & S & - & Calibração \\
D & FL2 & S & - & E.coli & S & - & Calibração \\
E & FL4 & S & - & - & S & S & \% Neutrófilo \\
F & Ensaio 01 & S & S & Sapi & S & S & Fagocitose/Burst \\
G & Ensaio 02 & S & S & E.coli & S & S & Fagocitose/Burst
\end{tabular}

Legenda: S.M. - Secreção Mamária; Bact - Bactéria; S - Acrescido no tubo.

Fonte: (SILVA, C. P. C., 2013) 
Figura 10 - Avaliação da proporção de neutrófilos no sangue de vacas Holandesas no período de transição: (A) Distribuição dos leucócitos sanguíneos; (B) Seleção dos neutrófilos $\mathrm{CH} 138^{+}$em relação ao total de eventos adquiridos - São Paulo - 2013

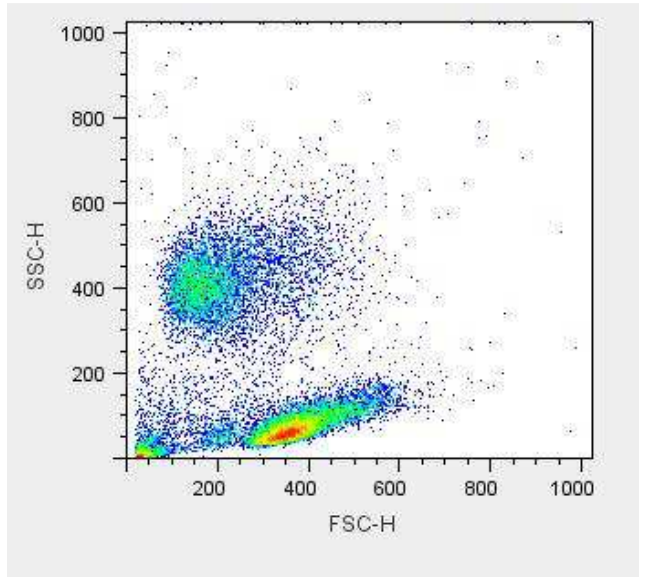

(A)

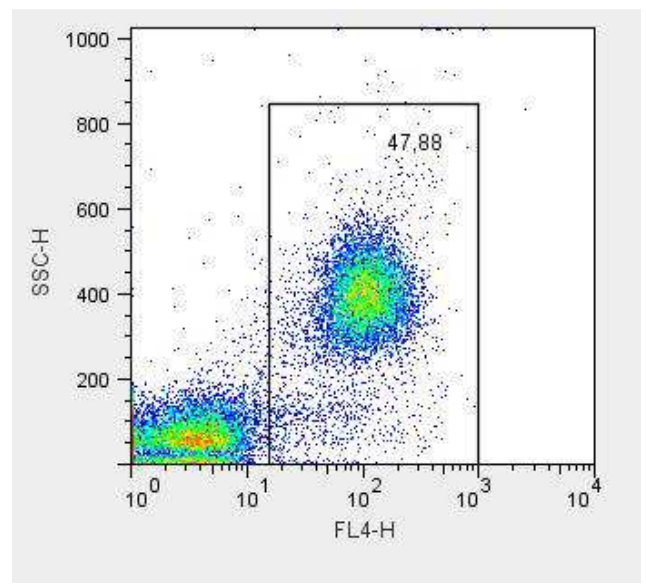

(B)

Fonte: (SILVA, C. P. C., 2013)

Figura 11 - Avaliação da proporção de neutrófilos $\mathrm{CH}_{138^{+}}$no colostro de vacas Holandesas: (A) Distribuição dos leucócitos do colostro proveniente de glândula mamária infectada, após separação das células PMN por gradiente de densidade; (B) Seleção dos neutrófilos $\mathrm{CH} 138^{+}$em relação ao total de eventos adquiridos - São Paulo - 2013

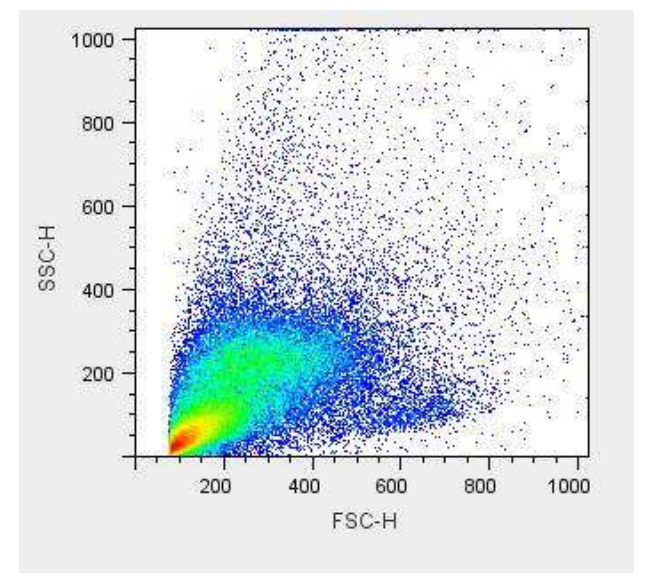

(A)

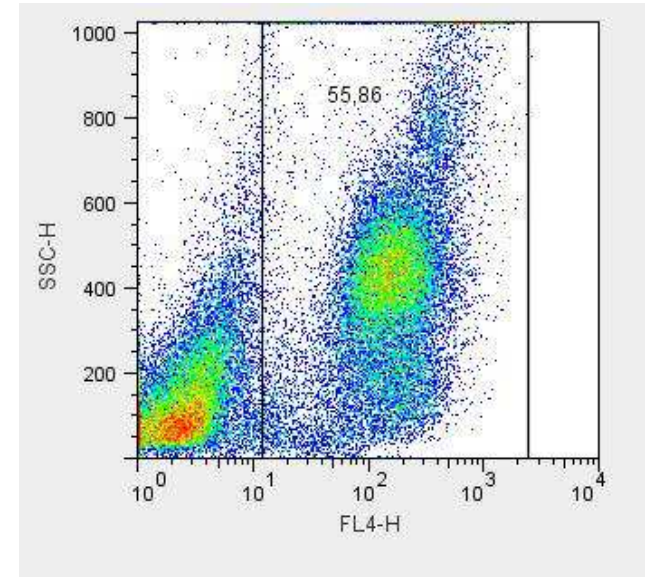

(B)

Fonte: (SILVA, C. P. C., 2013) 
Figura 12 - Avaliação da proporção de neutrófilos do leite de vacas Holandesas no período de transição: (A) Distribuição dos leucócitos sanguíneos totais do leite; (B) Seleção dos neutrófilos $\mathrm{CH} 138^{+}$em relação ao total de eventos adquiridos - São Paulo - 2013

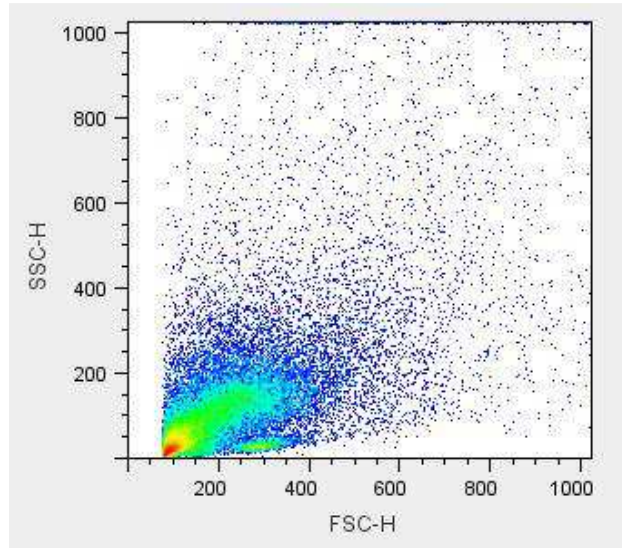

(A)

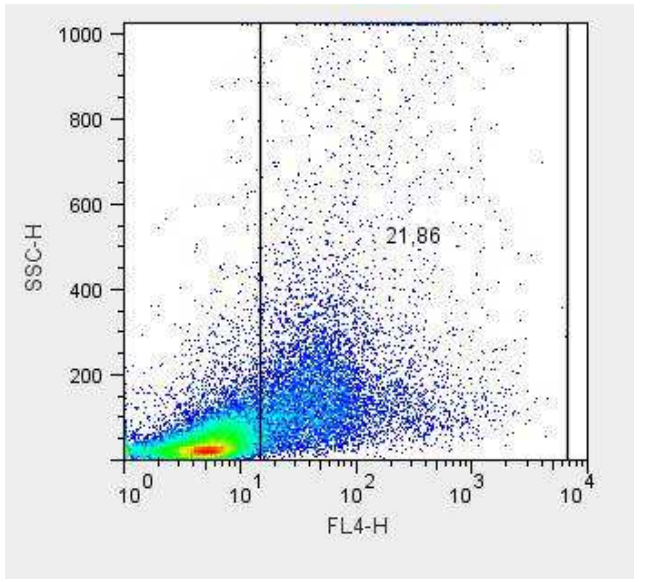

(B)

Fonte: (SILVA, C. P. C., 2013)

Figura 13 - Avaliação da fagocitose das células $\mathrm{CH}_{138^{+}}$do sangue de vacas Holandesas no periparto: (A) Seleção das células $\mathrm{CH}_{138^{+}}$(FL4) em relação ao total de eventos adquiridos; (B) Proporção de células $\mathrm{CH} 138^{+}$que fagocitaram bactéria marcada (FL2) - São Paulo - 2013

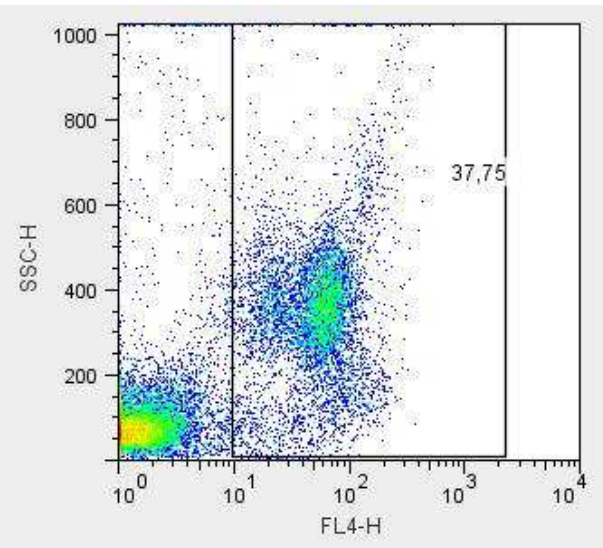

(A)

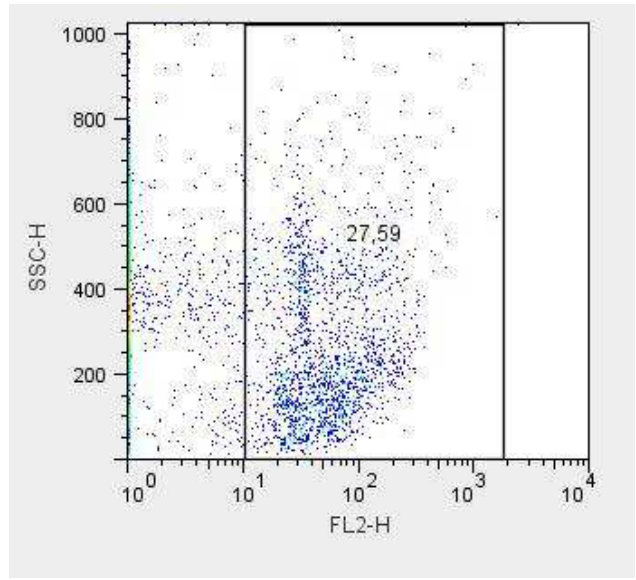

(B)

Fonte: (SILVA, C. P. C., 2013). 
Figura 14 - Avaliação da produção de $\mathrm{H}_{2} \mathrm{O}_{2}$ pelas células $\mathrm{CH} 138^{+}$do sangue de vacas Holandesas no período de transição: (A) Seleção da população $\mathrm{CH} 138^{+}$(FL4) em relação ao total de eventos adquiridos; (B) Seleção do eixo FL1 para avaliação da produção de $\mathrm{H}_{2} \mathrm{O}_{2}$ basal pelas células $\mathrm{CH}_{138^{+}}$(FL4); (C) Seleção do eixo $\mathrm{FL} 1$ para avaliação da produção de $\mathrm{H}_{2} \mathrm{O}_{2}$ com baixa (Low - população esquerda) e alta fluorescência (High - população direita) pelos neutrófilos $\mathrm{CH} 138^{+}$(FL4) com estímulo bacteriano - São Paulo - 2013

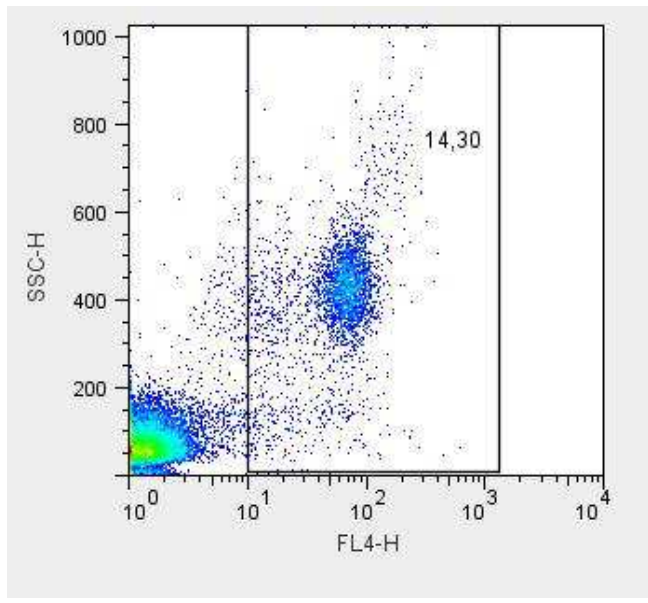

(A)

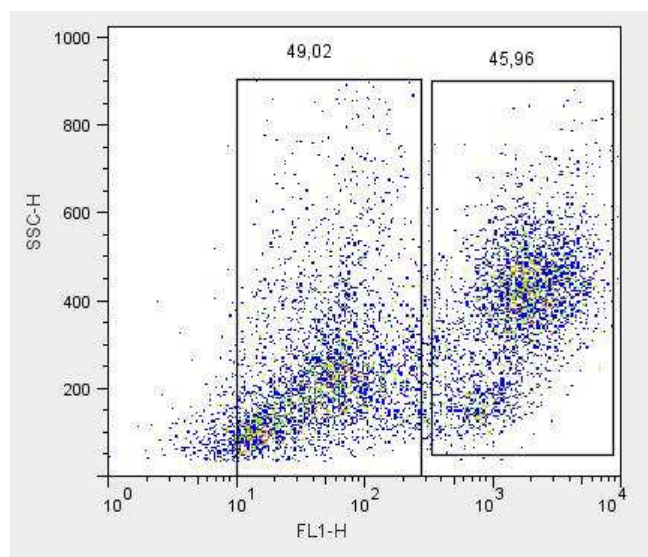

(C)

Fonte: (SILVA, C. P. C., 2013).

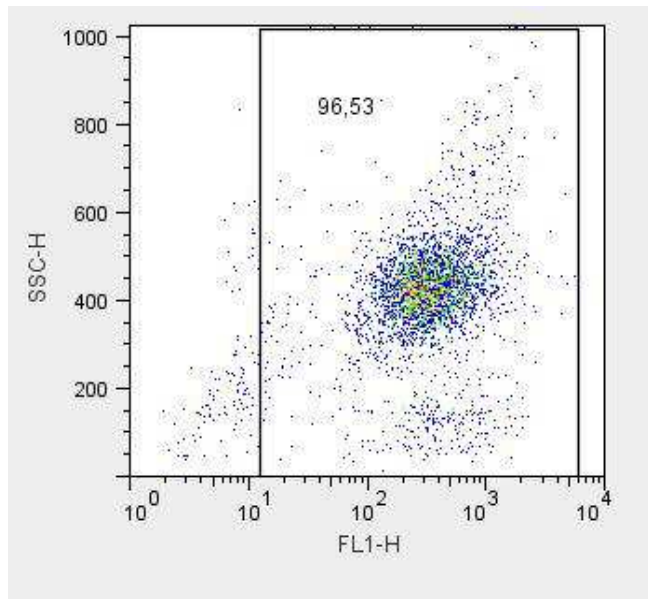

(B) 
Figura 15 - Avaliação da fagocitose das células $\mathrm{CH} 138^{+}$do colostro de vacas Holandesas: (A) Seleção das células $\mathrm{CH}_{138^{+}}$(FL4) em relação ao total de eventos adquiridos e após separação das amostras por gradiente de densidade; (B) Proporção de células $\mathrm{CH}_{138^{+}}$que fagocitaram Staphylococcus aureus (C) e Escherichia coli São Paulo - 2013

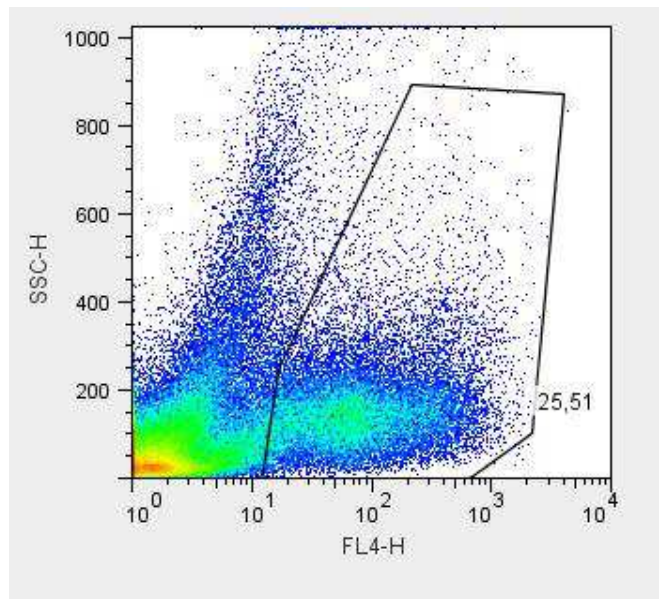

(A)
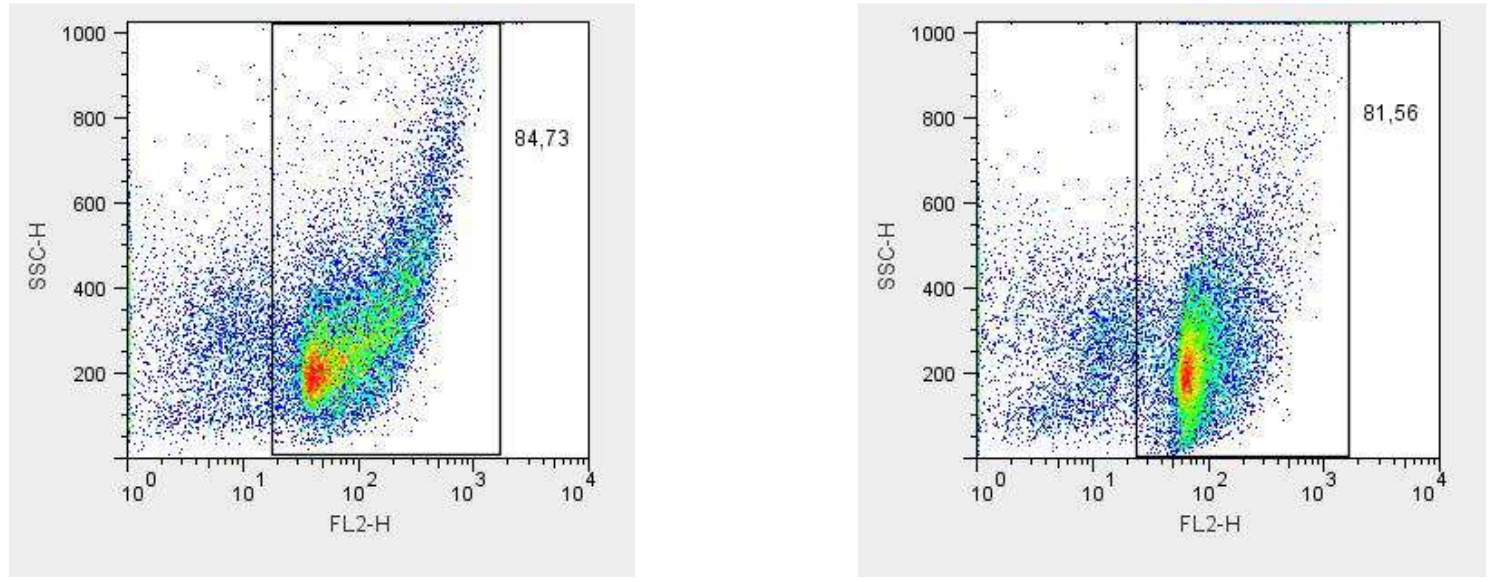

(B)

(C)

Fonte: (SILVA, C. P. C., 2013) 
Figura 16 - Avaliação da produção de $\mathrm{H}_{2} \mathrm{O}_{2}$ pelas células $\mathrm{CH}_{138^{+}}$do colostro de vacas Holandesas. (A) Seleção da população $\mathrm{CH}_{138^{+}}$(FL4) em relação ao total de eventos adquiridos. (B) Seleção do eixo $\mathrm{FL} 1$ para avaliação da produção de $\mathrm{H}_{2} \mathrm{O}_{2}$ basal pelas células $\mathrm{CH}_{138^{+}}$(FL4). (C) Seleção do eixo FL1 para avaliação da produção de $\mathrm{H}_{2} \mathrm{O}_{2}$ com baixa (Low - população esquerda) e alta fluorescência (High - alta fluorescência), respectivamente, pelos $\mathrm{CH}_{138^{+}}$(FL4) com estímulo bacteriano - São Paulo - 2013

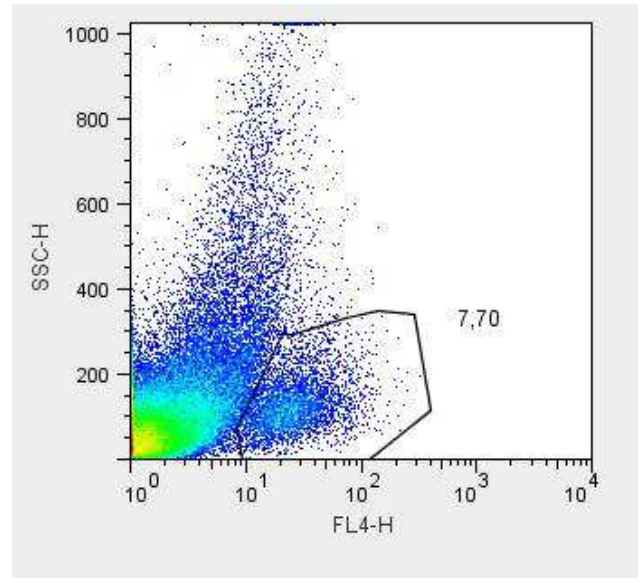

(A)

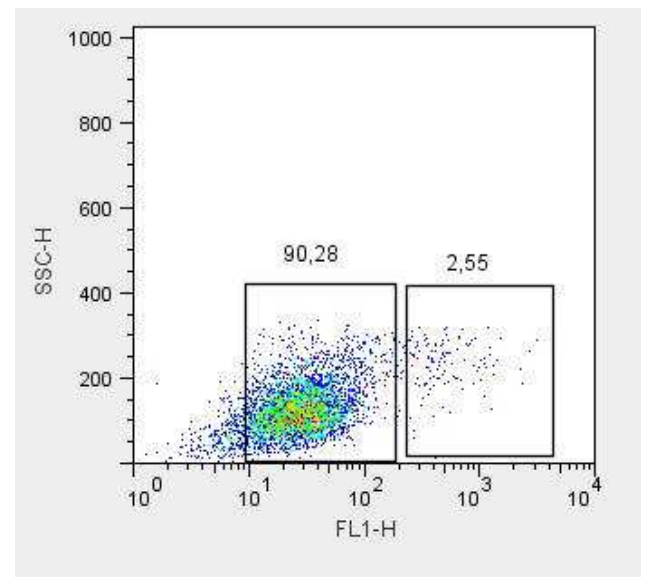

(C)

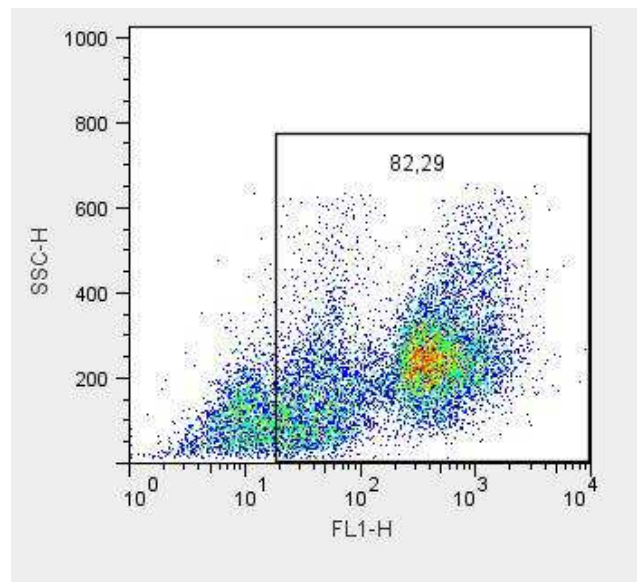

(B)

Fonte: (SILVA, C. P. C., 2013) 
Figura 17 - Avaliação da produção de $\mathrm{H}_{2} \mathrm{O}_{2}$ pelas células $\mathrm{CH} 138^{+}$do leite de vacas Holandesas. (A) Seleção da população $\mathrm{CH}_{138^{+}}$(FL4) em relação ao total de eventos adquiridos. (B) Seleção do eixo FL1 para avaliação da produção de $\mathrm{H}_{2} \mathrm{O}_{2}$ basal pelas células $\mathrm{CH} 138^{+}$(FL4). (C) Seleção do eixo FL1 para avaliação da produção de $\mathrm{H}_{2} \mathrm{O}_{2}$ com baixa ( $L$ ow - população esquerda) e alta fluorescência (High - alta fluorescência), respectivamente, pelos $\mathrm{CH}_{138^{+}}$(FL4) com estímulo bacteriano - São Paulo - 2013

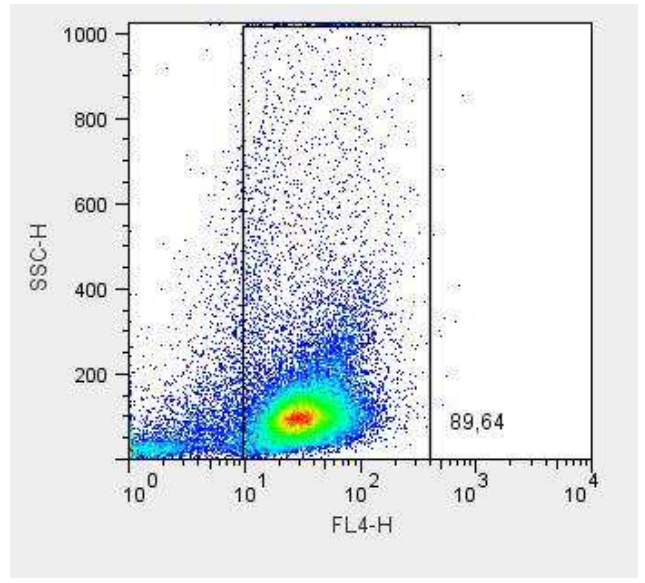

(A)

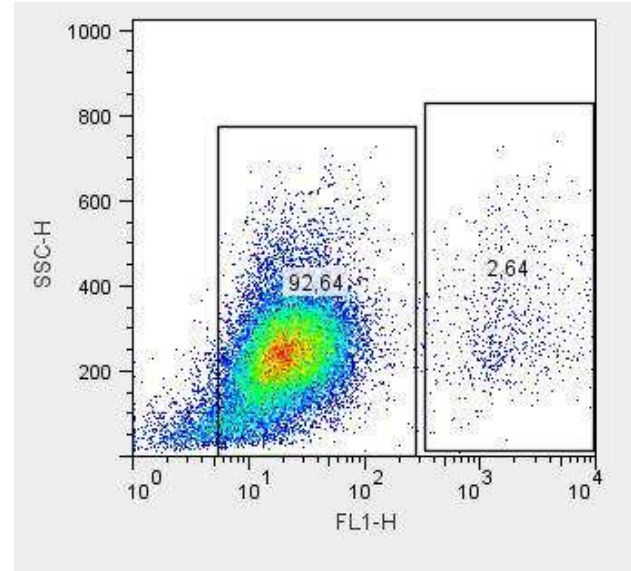

(C)

Fonte: (SILVA, C. P. C., 2013)

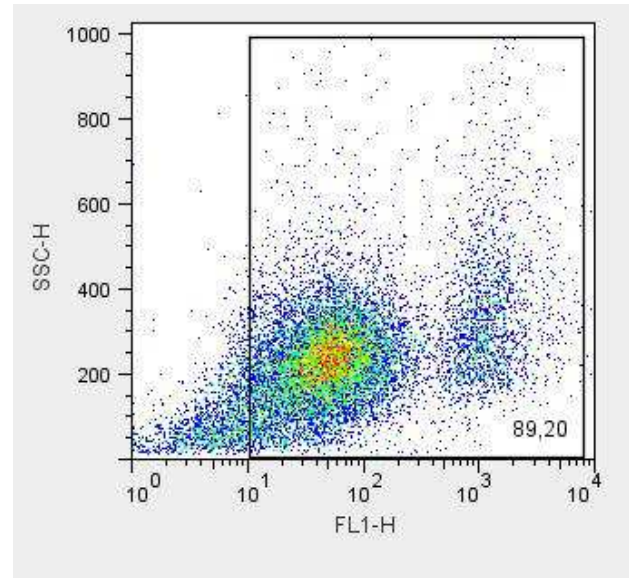

(B) 


\subsubsection{Mensuração de Citocina - Interferon y}

As alíquotas destinadas à mensuração de Interferon $\mathrm{y}$ do sangue, após separação do soro, foram congeladas em epperndorfs. As amostras de colostro e leite foram congeladas em tubos cônicos de $50 \mathrm{~mL}$. Todas as amostras foram congelas e mantidas a $-80^{\circ} \mathrm{C}$. Para analisar as amostras de secreção mamária, as mesmas foram centrifugadas a $40.000 \mathrm{~g}$ por 30 minutos a $4^{\circ} \mathrm{C}$ para obtenção do soro.

A mensuração do Interferon $y$ foi realizada pelo teste imunoenzimático ELISA seguindo as instruções do fabricante.

\subsubsection{Análise estatística}

A análise estatística e gráficos apresentados foram realizados utilizando-se o programa estatístico SPSS 20.0 (IBM Corp. Released 2011. IBM SPSS Statistics for Windows, Version 20.0. Armonk, NY: IBM Corp.).

Primeiramente, todas as variáveis em todos os momentos foram testadas quanto à aderência a distribuição normal pelo teste de Kolmogorov-Smirnov. Com este teste, constatou-se que houve variáveis com distribuição normal e outras não, então optou-se por testes não paramétricos em todas as análises. Além disso, o baixo número de animais em cada grupo favoreceu o poder estatístico dos testes não paramétricos em todas as análises.

Foram calculadas as freqüências dos dados qualitativos e dependentes, aplicando-se o teste de Cochran, para avaliar diferenças em relação aos momentos $(P \leq 0.05)$. A este último teste, quando apresentou pelo menos um momento significantemente diferente, foram realizadas comparações múltiplas pelo teste posthoc McNemar com correção de Bonferroni para comparações múltiplas.

As amostras dependentes com valores quantitativos foram analisadas pelo Teste de Friedman, para avaliar a diferença entre os tempos. A este último teste, quando apresentou, pelo menos um tempo significativamente diferente, foram 
realizadas as comparações múltiplas por meio do teste de Wilcoxom com correção de Bonferroni.

Todos os testes foram considerados significativos quando $p<0,05$. 


\section{RESULTADOS}

Neste tópico serão apresentados os resultados obtidos, considerando o status de higidez das GM e a resposta imune inata no sangue e secreção mamária das vacas Holandesas no período de transição. Optou-se por incluir o histórico de doenças da produção, para melhorar a qualidade da interpretação dos resultados e discussão apresentada.

\subsection{DOENÇAS DA PRODUÇÃO NO PERÍODO DE TRANSIÇÃO}

Durante o período de estudo foi relatada a ocorrência de doenças da produção nas vacas Holandesas, selecionadas para o desenvolvimento desta pesquisa. No período pré-parto ( $M-3$ ao $M 3$ ) não foram relatadas enfermidades e os animais não foram submetidos a protocolos terapêuticos.

Os distúrbios iniciaram-se a partir da parição, observando-se episódios de distocias em 4/13 vacas deste estudo, sendo que uma delas evoluiu para um quadro de cetose. No pós-parto imediato, observaram-se distúrbios do sistema reprodutivo (Quadro 4).

As alterações mamárias serão descritas posteriormente, considerando os achados obtidos pelas técnicas semiológicas de inspeção e palpação da GM, associadas ao exame do leite. 
Quadro 4 - Ocorrência de doenças da produção em vacas Holandesas no período de transição - São Paulo - 2013

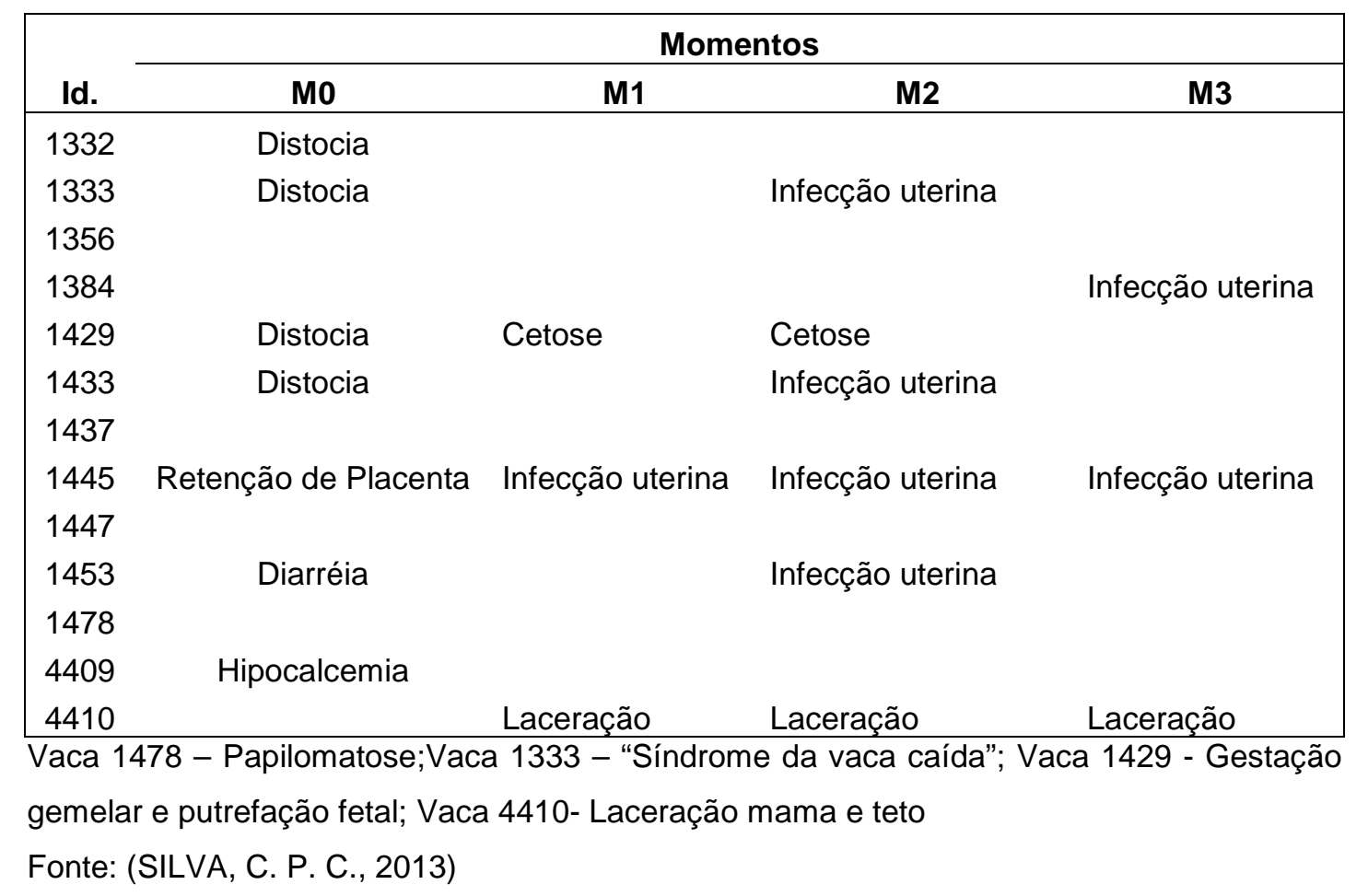

\subsection{EXAME ESPECÍFICO DA GM}

\subsubsection{Inspeção e Palpação}

A análise descritiva dos parâmetros e quesitos obtidos no exame específico da GM do M-3 a M3 está expressa em freqüências na tabela 1. Foi possível observar variações entre os momentos estudados para os quesitos volume generalizado $(P=0,000)$, volume localizado $(P=0,032)$, assimetria $(P=0,043)$ entre os quartos mamários, coloração $(P=0,000)$, elasticidade $(P=0,000)$, temperatura $(P=0,000)$ e consistência $(P=0,000)$ da $G M$. Na palpação dos linfonodos retromamários, não foram observadas diferenças entre os momentos avaliados $(P=0,451)$. As diferenças obtidas confrontando-se os momentos estão dispostas na tabela 2. 
O volume generalizado foi observado com maior frequência no parto (M0) em relação aos demais momentos, exceto M1. Também foi possível observar diferenças entre as frequências, confrontando os momentos do pré-parto em relação aos pósparto.

No quesito volume localizado, foi possível observar diferenças entre o momento M-3 em relação a M1. Na avaliação da assimetria observou-se diferença entre as frequências obtidas no momento M-3 em relação a M2.

No quesito coloração, observaram-se diferenças entre as frequências do momento M2 em relação aos momentos pré-parto (M-3, M-2, M-1) e M1.

$\mathrm{Na}$ elasticidade dos quartos mamários, observaram-se variações entre as frequências confrontando-se todos os momentos avaliados, com exceção do M-2 que se apresentou de forma semelhante ao M2 e M3.

Ao realizar a avaliação da temperatura local dos quartos mamários, foi possível detectar variações entre a maioria dos momentos avaliados, com exceção do $\mathrm{M}-1$ que foi semelhante a M-2, M2 e M3.

Ao se avaliar a consistência da mama, foi possível verificar no momento do parto (M0) a menor taxa de animais com consistência macia, se apresentado diferente dos momentos pré-parto (M-3 e M-2) e pós-parto (M1 e M3). O M-3 apresentou diferença entre todos os momentos avaliados.

As diferenças obtidas entre os momentos pelo teste de McNemar estão dispostas na tabela 2. 
Tabela 1 - Frequências (\%) dos quesitos obtidos pela inspeção e palpação dos quartos mamários de vacas Holandesas no período de transição - São Paulo - 2013

\begin{tabular}{|c|c|c|c|c|c|c|c|}
\hline Exame Físico & M-3 & M-2 & M-1 & M0 & M1 & M2 & M3 \\
\hline \multicolumn{8}{|c|}{ Inspeção - Unidade Quarto Mamário } \\
\hline Volume generalizado - ausente & 85 & 75 & 88 & 27 & 38 & 50 & 81 \\
\hline Volume generalizado - presente & 15 & 25 & 12 & 73 & 62 & 50 & 19 \\
\hline Volume localizado - ausente & 88 & 95 & 95 & 100 & 100 & 94 & 96 \\
\hline Volume localizado - presente & 12 & 5 & 5 & 0 & 0 & 6 & 4 \\
\hline Coloração normal & 92 & 100 & 100 & 90 & 98 & 85 & 92 \\
\hline Coloração avermelhada & 8 & 0 & 0 & 10 & 2 & 13 & 8 \\
\hline Coloração arroxeada & 0 & 0 & 0 & 0 & 0 & 2 & 0 \\
\hline \multicolumn{8}{|c|}{ Palpação - Unidade Quarto Mamário } \\
\hline Elasticidade normal & 83 & 36 & 88 & 0 & 12 & 38 & 38 \\
\hline Elasticidade diminuída & 17 & 64 & 12 & 100 & 88 & 62 & 62 \\
\hline Temperatura normal & 92 & 79 & 86 & 8 & 62 & 94 & 85 \\
\hline Temperatura elevada & 8 & 21 & 14 & 92 & 38 & 6 & 15 \\
\hline Consistência Macia & 52 & 39 & 21 & 12 & 31 & 23 & 100 \\
\hline Consistência Endurecida & 8 & 29 & 21 & 42 & 15 & 0 & 0 \\
\hline Consistência Edemaciada & 40 & 32 & 58 & 46 & 54 & 77 & 60 \\
\hline \multicolumn{8}{|c|}{ Inspeção - Unidade Animal } \\
\hline Assimetria - ausente & 85 & 86 & 71 & 42 & 77 & 46 & 54 \\
\hline Assimetria - presente & 15 & 14 & 29 & 58 & 23 & 54 & 46 \\
\hline \multicolumn{8}{|c|}{ Palpação - Unidade Animal } \\
\hline Linfonodos normais & 46 & 58 & 64 & 50 & 54 & 62 & 54 \\
\hline Um linfonodo aumentado & 23 & 21 & 7 & 25 & 38 & 15 & 23 \\
\hline Dois linfonodos aumentados & 31 & 21 & 29 & 25 & 8 & 23 & 23 \\
\hline
\end{tabular}

Fonte: (SILVA, C. P. C., 2013) 
Tabela 2 - Diferenças estatísticas obtidas entre os momentos segundo o teste de Teste de McNemar

(continua)

\begin{tabular}{|c|c|c|c|c|c|c|}
\hline \multicolumn{7}{|c|}{ Volume Generalizado } \\
\hline & $\mathrm{M}-2$ & $\mathrm{M}-1$ & MO & M1 & M2 & M3 \\
\hline$M-3$ & 0.031 & 0.727 & 0.000 & 0.000 & 0.000 & 0.031 \\
\hline$M-2$ & & 0.388 & 0.000 & 0.000 & 0.000 & 1 \\
\hline$M-1$ & & & 0.000 & 0.000 & 0.000 & 0.388 \\
\hline M0 & & & & 0.167 & 0.003 & 0.000 \\
\hline M1 & & & & & 0.21 & 0.000 \\
\hline M2 & & & & & & 0.000 \\
\hline \multicolumn{7}{|c|}{ Volume localizado } \\
\hline & $M-2$ & $M-1$ & Mo & M1 & M2 & M3 \\
\hline$M-3$ & 0.125 & 0.453 & 0.063 & 0.031 & 0.375 & 0.125 \\
\hline$M-2$ & & 1 & 0.5 & 0.25 & 1 & 1 \\
\hline$M-1$ & & & 1 & 0.25 & 1 & 1 \\
\hline M0 & & & & NA & 0.5 & 1 \\
\hline M1 & & & & & 0.25 & 0.5 \\
\hline M2 & & & & & & 1 \\
\hline \multicolumn{7}{|c|}{ Assimetria } \\
\hline & $\mathrm{M}-2$ & $\mathrm{M}-1$ & MO & M1 & M2 & M3 \\
\hline$M-3$ & 1 & 0.625 & 0.070 & 0.500 & 0.031 & 0.219 \\
\hline M-2 & & 1 & 0.125 & 1 & 0.180 & 0.219 \\
\hline$M-1$ & & & 0.063 & 1 & 0.219 & 0.250 \\
\hline M0 & & & & 0.219 & 1 & 0.625 \\
\hline M1 & & & & & 0.289 & 0.453 \\
\hline M2 & & & & & & 1 \\
\hline \multicolumn{7}{|c|}{ Coloração } \\
\hline & M-2 & $M-1$ & MO & M1 & $\mathrm{M} 2$ & M3 \\
\hline$M-3$ & NA & NA & 0.063 & 1 & 0.008 & 0.125 \\
\hline M-2 & & NA & 0.063 & 1 & 0.008 & 0.125 \\
\hline$M-1$ & & & 0.063 & 1 & 0.008 & 0.125 \\
\hline MO & & & & 0.219 & 0.581 & 1 \\
\hline M1 & & & & & 0.039 & 0.375 \\
\hline M2 & & & & & & 0.125 \\
\hline \multicolumn{7}{|c|}{ Elasticidade } \\
\hline & M-2 & $M-1$ & MO & M1 & M2 & M3 \\
\hline$M-3$ & 0.000 & 0.000 & 0.000 & 0.000 & 0.000 & 0.000 \\
\hline$M-2$ & & 0.000 & 0.000 & 0.011 & 1 & 1 \\
\hline$M-1$ & & & 0.031 & 1 & 0.004 & 0.001 \\
\hline MO & & & & 0.031 & 0.000 & 0.000 \\
\hline M1 & & & & & 0.001 & 0.011 \\
\hline M2 & & & & & & 1 \\
\hline
\end{tabular}


(conclusão)

\begin{tabular}{|c|c|c|c|c|c|c|}
\hline \multicolumn{7}{|c|}{ Temperatura } \\
\hline & $M-2$ & $\mathrm{M}-1$ & MO & M1 & M2 & M3 \\
\hline M-3 & 0.000 & 0.031 & 0.000 & 0.000 & 0.25 & 0.125 \\
\hline M-2 & & 0.109 & 0.000 & 0.115 & 0.035 & 0.388 \\
\hline$M-1$ & & & 0.000 & 0.011 & 0.508 & 0.687 \\
\hline MO & & & & 0.000 & 0.000 & 0.000 \\
\hline M1 & & & & & 0.000 & 0.038 \\
\hline M2 & & & & & & 0.227 \\
\hline \multicolumn{7}{|c|}{ Consistência } \\
\hline & $M-2$ & $M-1$ & MO & M1 & M2 & M3 \\
\hline M-3 & 0.021 & 0.000 & 0.000 & 0.027 & 0.001 & 0.052 \\
\hline M-2 & & 0.013 & 0.001 & 0.286 & 0.064 & 1 \\
\hline$M-1$ & & & 0.267 & 0.503 & 1 & 0.049 \\
\hline MO & & & & 0.052 & 0.109 & 0.001 \\
\hline M1 & & & & & 0.571 & 0.441 \\
\hline M2 & & & & & & 0.124 \\
\hline
\end{tabular}

Fonte: (SILVA, C. P. C., 2013) 


\subsection{EXAME BACTERIOLÓGICO DO LEITE}

Das 376 amostras de secreção mamária colhidas do M-3 ao M3 para o exame bacteriológico, obteve-se crescimento bacteriano em 88 delas $(23,41 \%)$. As freqüências de isolamentos positivos por momentos analisados foram: 25\% M-3; $21,43 \%$ M-2; 26,79\% M-1; 33,34\% M0; 21,16\% M1; 7,7\% M2; e $17,31 \%$ no M3 (Figura 18).

As freqüências dos resultados do exame bacteriológico estão apresentadas na Figura 18. Foi possível detectar variações entre os momentos avaliados $(P=0,018)$. Na semana $M 2$, observou-se menor taxa de infecção mamária $(7,7 \%)$, apresentando-se diferente de todos os momentos avaliados, exceto o M3.

Dos gêneros bacterianos isolados $(n=88), 70,45 \%$ foram Staphylococcus coagulase-negativa; $13,63 \%$ Corynebacterium spp.; 11,36 Streptococcus spp.; $3,40 \%$ Serratia marcescens, e 1,13\% Staphylococcus coagulase-positiva.
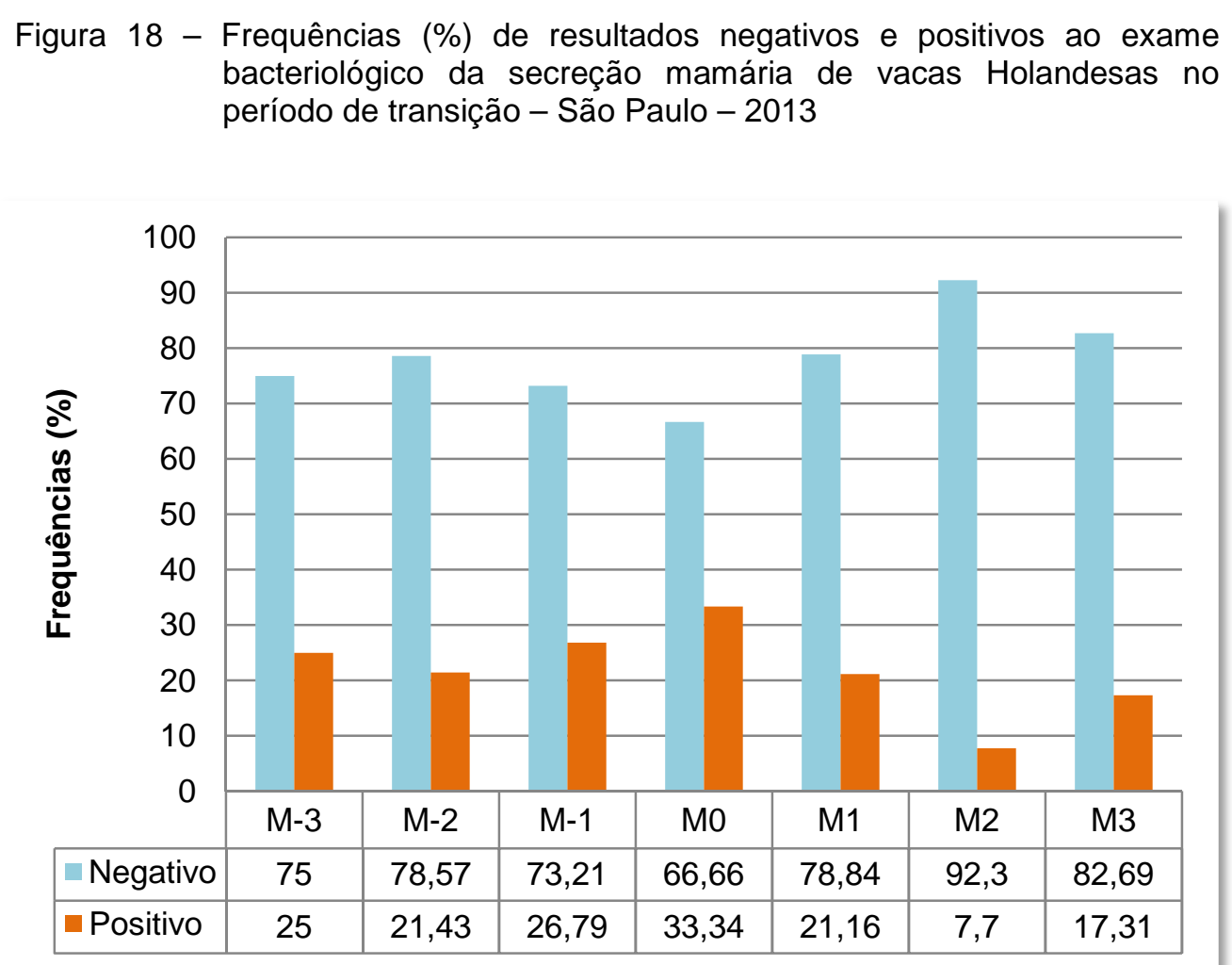

Fonte: (SILVA, C. P. C., 2013) 


\subsection{RESPOSTA IMUNE INATA NO SANGUE}

4.4.1 Proporção (\%) de PMN e de neutrófilos $\mathrm{CH} 138^{+}$

A média e mediana da proporção (\%) de $\mathrm{PMN}$ e neutrófilos $\mathrm{CH} 138^{+}$presentes no sangue das vacas Holandesas durante 0 período de transição estão apresentadas na tabela 3. A distribuição e mediana dos dados estão apresentadas na figura 19.

A proporção de PMN apresentou variações no período de transição $(\mathrm{P}=0,000)$, observando diferenças entre os valores medianos detectados no $\mathrm{M0}$ $(42,6 \%)$ em relação ao pré-parto; e $M 1$ (10,82\%) em relação ao $M-2(31,2 \%)$ e M3 $(31,8 \%)$.

A proporção de neutrófilos $\mathrm{CH} 138^{+}$também apresentou oscilações do $\mathrm{M}-3$ ao $M 3$, detectando diferenças entre momentos avaliados $(P=0,001)$. As diferenças foram observadas entre o momento $\mathrm{M0}(47 \%)$ em relação a todos os momentos pré (M-1 - 27,36; M-2 - 33,8; M-1 - 23,07) e pós-parto (M1 - 14,08; M2 - 23,31; M3 $34,1)$, e $M-1$ em relação ao M-2 e M3. 
Tabela 3 - Proporção (\%) de leucócitos PMN e neutrófilos $\mathrm{CH}_{138^{+}}$ presentes no sangue de vacas Holandesas durante o período de transição - São Paulo - 2013

\begin{tabular}{|c|c|c|c|c|c|c|c|}
\hline \multicolumn{8}{|c|}{ Leucócitos Polimorfonucleares (\%) } \\
\hline Semanas & M-3 & M-2 & $\mathrm{M}-1$ & M0 & M1 & M2 & M3 \\
\hline Média & 24,3 & 31,3 & 24,0 & 40,7 & 16,4 & 27,1 & 31,5 \\
\hline Mediana & 25,0 & 31,2 & 21,1 & 42,6 & 10,8 & 23,6 & 31,8 \\
\hline Mínimo & 7,1 & 13,7 & 5,2 & 20,9 & 2,6 & 9,3 & 10,5 \\
\hline Máximo & 37,7 & 53,3 & 44,6 & 61,7 & 42,1 & 60,4 & 59,6 \\
\hline \multicolumn{8}{|c|}{ Neutrófilos $\mathrm{CH}_{138^{+}}(\%)$} \\
\hline Média & 27,6 & 32,5 & 22,2 & 43,6 & 21,5 & 24,7 & 30,4 \\
\hline Mediana & 27,4 & 33,8 & 23,1 & 47,0 & 14,1 & 23,3 & 34,1 \\
\hline Mínimo & 7,6 & 20,3 & 3,9 & 22,2 & 2,4 & 8,1 & 11,4 \\
\hline Máximo & 48,1 & 43,9 & 41,3 & 66,4 & 46,4 & 60,7 & 46,7 \\
\hline
\end{tabular}

Fonte: (SILVA, C. P. C., 2013)

Figura 19 - Proporção (\%) de células PMN (A) e $\mathrm{CH} 138^{+}$(B) no sangue de vacas Holandesas no período de transição - São Paulo - 2013

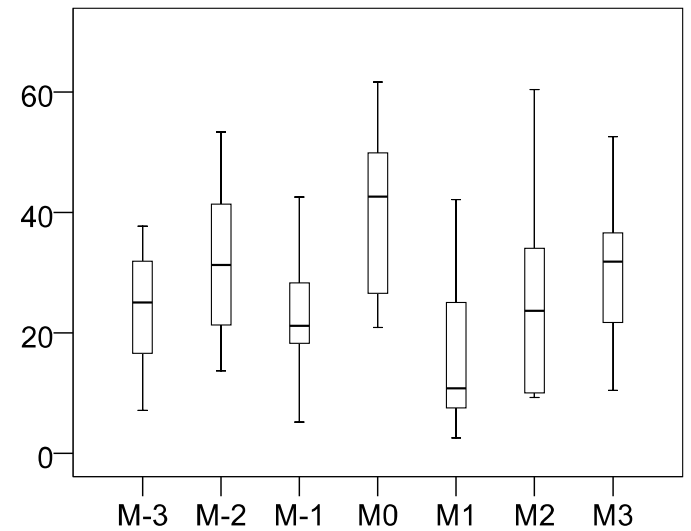

(A)

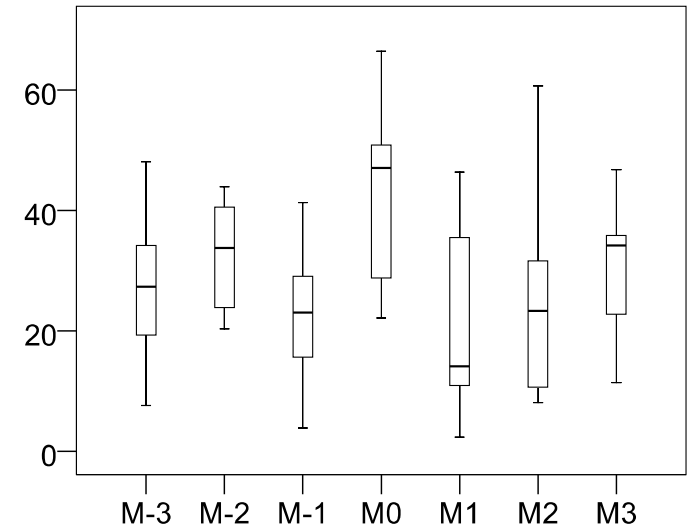

(B)

Fonte: (SILVA, C. P. C., 2013) 
4.4.2 Valores absolutos de leucócitos totais e neutrófilos $\mathrm{CH} 138^{+}$

A mediana dos leucócitos totais sanguíneos avaliados da semana M-3 a M3, respectivamente foram 13,$1 ; 13,1 ; 13,0 ; 21,5 ; 11,2 ; 11,1 ; 12,2\left(\times 10^{3}\right)$. Foi possível detectar variação entre os momentos analisados $(P=0,000)$. Observou-se maior número absoluto de leucócitos no momento da parição $\left(21,5 \times 10^{3}\right)$, apresentando diferença em relação a todos os outros momentos avaliados; e entre $M-1$ em relação ao M-2 e M1 (Tabela 4 e Figura 20).

O valor mediano absoluto dos neutrófilos $\mathrm{CH}_{138^{+}}$sanguíneos observados durante o período de transição foi de 3,$7 ; 3,7 ; 3,5 ; 9,5 ; 3,2 ; 3,1 ; 3,5\left(\times 10^{3}\right)$, respectivamente do momento $\mathrm{M}-3$ ao $\mathrm{M} 3$. Observaram-se variações entre os valores, durante as semanas avaliadas $(\mathrm{P}=0,000)$. O pico de $\mathrm{CH} 138^{+}$foi observado no momento do parto $\left(9,5 \times 10^{3}\right)$, apresentando diferenças entre os outros momentos avaliados; e entre M-1 em relação aos momentos M-2 e M3 (Tabela 4 e Figura 20). 
Tabela 4 - Valor absoluto (VA) de leucócitos PMN e neutrófilos $\mathrm{CH} 138^{+}$presentes no sangue de vacas Holandesas durante o período de transição - São Paulo - 2013

\begin{tabular}{lccccccc}
\hline \multicolumn{7}{c}{ Leucócitos Polimorfonucleares (VA) } \\
\hline Semanas & M-3 & M-2 & M-1 & M0 & M1 & M2 & M3 \\
\hline Mediana & 3362 & 3694 & 3394 & 8753 & 1338 & 3010 & 4445 \\
\hline \multicolumn{7}{c}{ Neutrófilos } & CH138 \\
& (VA) & & & \\
\hline Semanas & M-3 & M-2 & M-1 & M0 & M1 & M2 & M3 \\
\hline Mediana & 3753 & 3717 & 3485 & 9514 & 3193 & 3106 & 3551 \\
\hline VA - Valor absoluto & & & & & &
\end{tabular}

Fonte: (SILVA, C. P. C., 2013)

Figura 20 - Valor absoluto (VA) de leucócitos PMN e neutrófilos $\mathrm{CH} 138^{+}$presentes no sangue de vacas Holandesas durante o período de transição - São Paulo - 2013

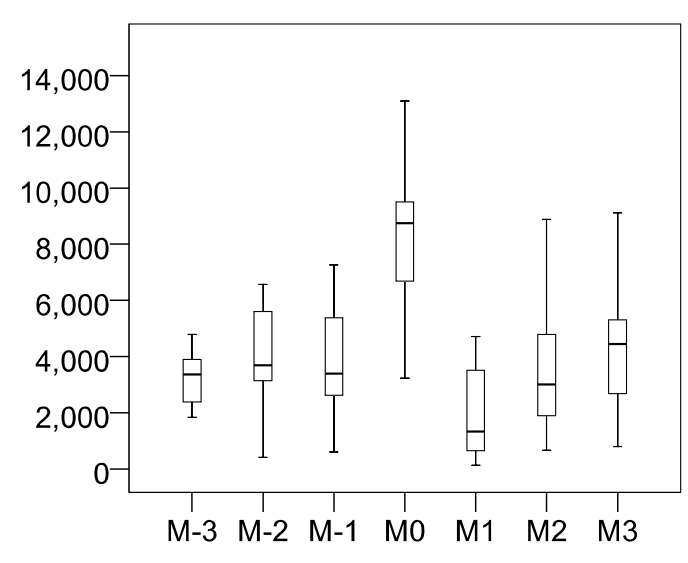

(A)

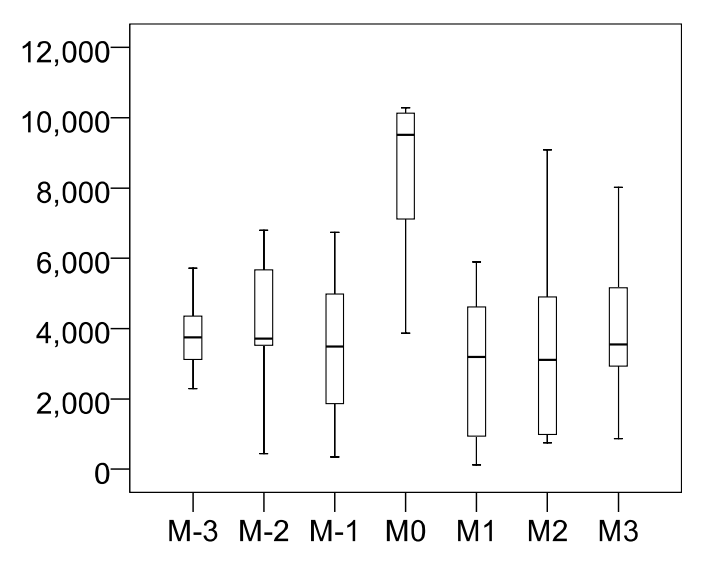

(B)

Fonte: (SILVA, C. P. C., 2013) 
4.4.3 Fagocitose de bactérias pelos neutrófilos $\mathrm{CH} 138^{+}$

\subsubsection{Fagocitose de Staphylococcus aureus}

A tabela 5 e figura 21 apresentam a proporção (\%) de células $\mathrm{CH} 138^{+}$que realizaram fagocitose, assim como a sua intensidade, representada pela média geométrica da fluorescência emitida na presença de estímulo bacteriano.

As proporções de células $\mathrm{CH}_{138^{+}}$que fagocitaram Staphylococcus aureus, nos momentos $\mathrm{M}-3$ ao $\mathrm{M} 3$, respectivamente, foram de 81,$41 ; 82,15$; 82,27; 80,94; 81,$37 ; 81,32$ e $85,34 \%$. Não foram observadas diferenças entre os momentos avaliados $(P=0,450)$. As médias geométricas da fluorescência emitidas foram de 161,$22 ; 79,23 ; 82,17 ; 103,09 ; 78,77 ; 117,80$ e 90,38 entre as semanas M-3 e M3, respectivamente, detectando diferenças entre os momentos avaliados ( $P=0,014)$. As oscilações foram observadas entre o momento M-3 $(161,22)$ em relação aos momentos M-2 $(79,23)$, M1 $(78,77)$, M2 $(117,80)$ e M3 $(90,38)$. 
Tabela 5 - Proporção (\%) e intensidade da fagocitose (Média Geométrica) de Staphylococcus aureus pelos neutrófilos $\mathrm{CH} 138^{+}$do sangue de vacas Holandesas no período de transição - São Paulo 2013

\begin{tabular}{lrlrrrrr}
\hline \multicolumn{7}{c}{ Staphylococcus aureus } \\
\hline M-3 & M-2 & M-1 & M0 & M1 & M2 & M3 \\
Média & 80,6 & 80,8 & 81,3 & 73,5 & 78,7 & 82,1 & 82,6 \\
Mediana & 81,4 & 82,1 & 82,3 & 80,9 & 81,4 & 81,3 & 85,3 \\
Mínimo & 57,1 & 63,1 & 38,7 & 34,9 & 60,3 & 71,0 & 60,6 \\
Máximo & 99,7 & 97,9 & 96,6 & 95,3 & 90,8 & 94,9 & 96,4 \\
\hline
\end{tabular}

\begin{tabular}{lrrrrrrr}
\hline \multicolumn{7}{c}{ Intensidade da fagocitose (Média Geométrica) } \\
\hline Média & 169,0 & 98,2 & 118,8 & 163,5 & 92,6 & 125,3 & 107,7 \\
Mediana & 161,2 & 79,2 & 82,2 & 103,1 & 78,8 & 117,8 & 90,4 \\
Mínimo & 40,4 & 21,7 & 37,0 & 19,4 & 39,8 & 28,2 & 45,4 \\
Máximo & 299,6 & 299,6 & 279,5 & 540,0 & 193,7 & 437,3 & 243,9 \\
\hline Fonte: (SILVA, C. P. C., 2013) & & & & &
\end{tabular}

Figura 21 - Proporção (\%) (A) e intensidade da fagocitose (B) de Staphylococcus aureus pelos neutrófilos $\mathrm{CH}_{138^{+}}$sanguíneos de vacas Holandesas no período de transição São Paulo - 2013

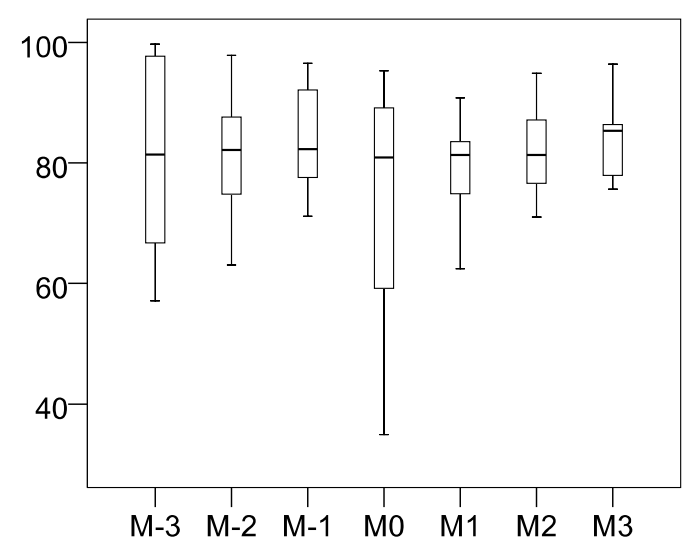

(A)

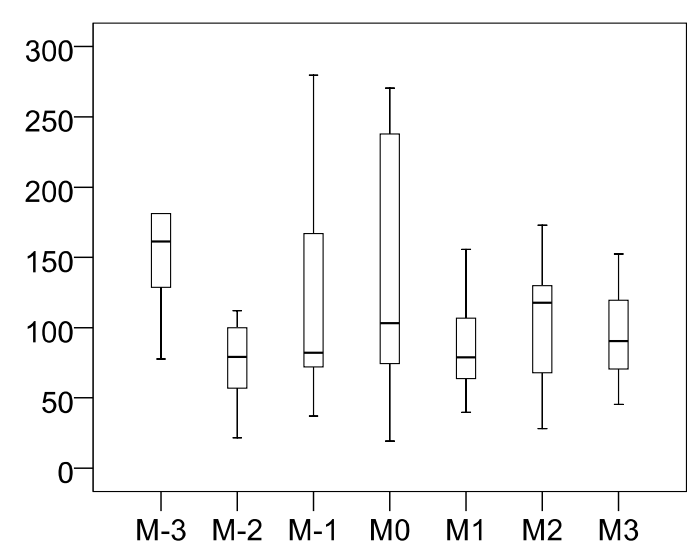

(B)

Fonte: (SILVA, C. P. C., 2013) 


\subsubsection{Fagocitose de Escherichia coli}

A proporção de $\mathrm{CH}_{138^{+}}$que fagocitaram Escherichia coli foram de 36,43; 66,$96 ; 75,1477,95 ; 78,83 ; 84,43$; e $75,87 \%$, entre as semanas M-3 a M3, respectivamente, não sendo observadas oscilações entre os momentos ( $P=0,065)$.

A intensidade da fagocitose obtida foi de 47,$02 ; 42,74 ; 91,31 ; 94,90 ; 52,71$; 103,14; e 98,73, respectivamente do M-3 ao M3, observando-se oscilações entre os momentos $(P=0,001)$ (Tabela 6 e Figura 22). Os valores aumentaram do pré-parto ao parto, observando-se diferenças entre M0 e M-3; e M0 versus M1. No M2 observou-se pico máximo de intensidade da fagocitose de Escherichia coli, detectando diferenças entre esse momento em comparação ao M-2 e M1. Os valores do M3 também foram maiores que os encontrados em M-2 e M1. 
Tabela 6 - Proporção (\%) e intensidade da fagocitose (Média Geométrica) de Escherichia coli pelos neutrófilos $\mathrm{CH} 138^{+}$ do sangue de vacas Holandesas no período de transição - São Paulo - 2013

\begin{tabular}{|c|c|c|c|c|c|c|c|}
\hline \multicolumn{8}{|c|}{ Escherichia coli } \\
\hline \multicolumn{8}{|c|}{ Fagocitose (\%) } \\
\hline & M-3 & M-2 & M-1 & MO & M1 & M2 & M3 \\
\hline Média & 47,0 & 62,5 & 71,7 & 67,8 & 65,8 & 82,2 & 74,4 \\
\hline Mediana & 36,4 & 67,0 & 75,1 & 77,9 & 78,8 & 84,4 & 75,9 \\
\hline Mínimo & 12,6 & 28,5 & 27,6 & 17,4 & 12,0 & 57,1 & 40,5 \\
\hline Máximo & 93,4 & 91,0 & 89,8 & 94,6 & 88,6 & 94,8 & 91,3 \\
\hline \multicolumn{8}{|c|}{ Intensidade da fagocitose (Média Geométrica) } \\
\hline Média & 74,8 & 55,5 & 97,1 & 156,4 & 65,1 & 114,1 & $\overline{9} 6,3$ \\
\hline Mediana & 47,0 & 42,7 & 91,3 & 94,9 & 52,7 & 103,1 & 98,7 \\
\hline Mínimo & 18,6 & 12,9 & 22,1 & 9,6 & 16,4 & 6,7 & 57,8 \\
\hline Máximo & 149,8 & 147,6 & 184,3 & 392,4 & 212,1 & 430,7 & 146,1 \\
\hline
\end{tabular}

Figura 22 - Proporção (\%) (A) e intensidade da fagocitose (B) de Escherichia coli pelos neutrófilos $\mathrm{CH} 138^{+}$sanguíneos de vacas Holandesas no período de transição São Paulo - 2013

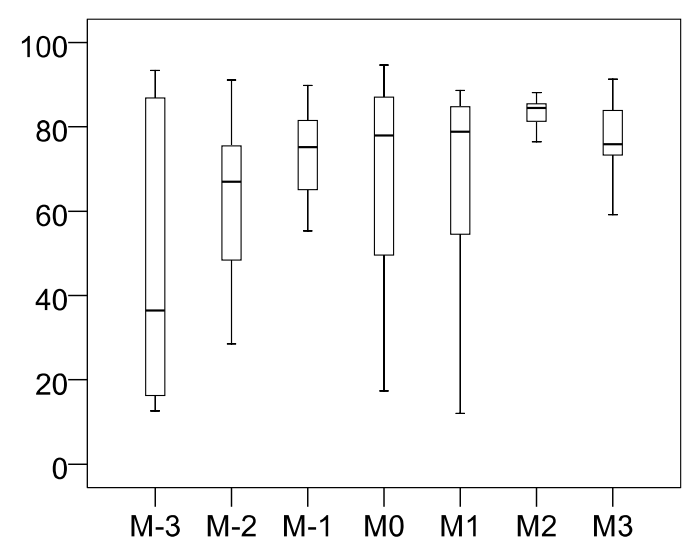

(A)

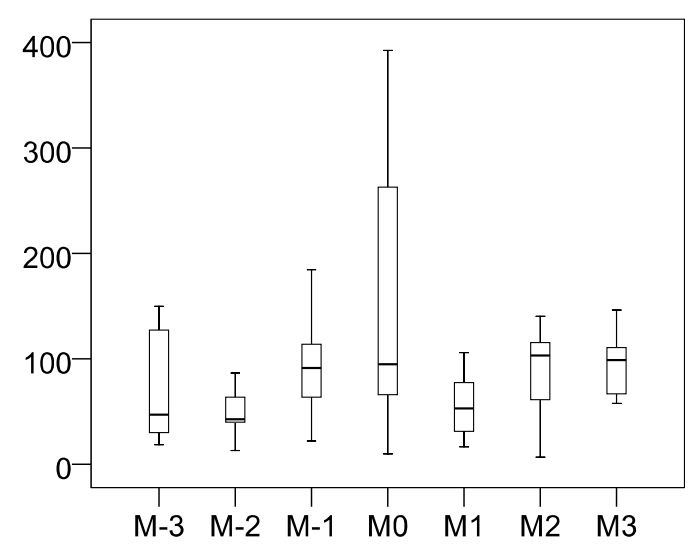

(B)

Fonte: (SILVA, C. P. C., 2013) 
4.4.4 Produção intracelular de peróxido de hidrogênio $\left(\mathrm{H}_{2} \mathrm{O}_{2}\right)$ pelos neutrófilos $\mathrm{CH} 138^{+}$

\subsubsection{Produção de $\mathrm{H}_{2} \mathrm{O}_{2}$ pelos $\mathrm{CH} 138^{+}$Basal}

A tabela 7 apresenta a proporção (\%) de células $\mathrm{CH}_{138^{+}}$que produziram $\mathrm{H}_{2} \mathrm{O}_{2}$ e a intensidade dessa produção, representada pela média geométrica da fluorescência emitida, com e sem a presença de um estímulo bacteriano. A figura 23 apresenta a distribuição e a mediana desses dados referentes à produção basal de $\mathrm{H}_{2} \mathrm{O}_{2}$.

A proporção de neutrófilos $\mathrm{CH}_{138^{+}}$produzindo $\mathrm{H}_{2} \mathrm{O}_{2}$ basal, da semana M-3 até $\mathrm{M} 3$ foi de 93,62; 90,51;94,13;95,20;93,96; 97,85;94,61, respectivamente. Pela análise estatística foi possível detectar oscilações entre os momentos avaliados $(P=0,049)$. As diferenças observadas foram entre as semanas $M-2(90,5 \%)$ em relação às semanas $M-1(94,1 \%)$ e M2 $(97,8 \%)$; e M1 $(94 \%)$ em relação a M2 $(97,8 \%)$.

A intensidade da produção intracelular de $\mathrm{H}_{2} \mathrm{O}_{2}$ observada foi de 378,33 ; 167,$39 ; 172,50 ; 328,77 ; 453,39 ; 482,71 ; 348,61$, para as semanas M-3 a M3, respectivamente, não sendo possível observar oscilações entre os momentos avaliados $(P=0,068)$. 
Tabela 7 - Valores relativos (\%) e média geométrica da produção basal de peróxido de hidrogênio pelos neutrófilos $\mathrm{CH} 138^{+}$sanguíneos de vacas Holandesas no período de transição - São Paulo - 2013

\begin{tabular}{|c|c|c|c|c|c|c|c|}
\hline \multicolumn{8}{|c|}{ Produção $\mathrm{H}_{2} \mathrm{O}_{2}$ - basal (\%) } \\
\hline & M-3 & M-2 & M-1 & M0 & M1 & M2 & M3 \\
\hline Média & 93,3 & 89,5 & 94,0 & 90,4 & 88,4 & 94,8 & 94,3 \\
\hline Mediana & 93,6 & 90,5 & 94,1 & 95,2 & 94,0 & 97,8 & 94,6 \\
\hline Mínimo & 82,7 & 80,3 & 81,0 & 48,4 & 57,7 & 69,1 & 86,5 \\
\hline Máximo & 98,5 & 96,8 & 99,3 & 99,3 & 98,8 & 99,7 & 98,3 \\
\hline \multicolumn{8}{|c|}{ Intensidade da Produção de $\mathrm{H}_{2} \mathrm{O}_{2}$ - basal (Média Geométrica) } \\
\hline Média & 458,7 & 207,0 & 268,3 & 384,1 & 458,0 & 540,0 & 355,0 \\
\hline Mediana & 378,3 & 167,0 & 172,5 & 328,8 & 453,0 & 483,0 & 349,0 \\
\hline Mínimo & 51,2 & 96,0 & 66,4 & 55,6 & 161,0 & 106,0 & 134,0 \\
\hline Máximo & 882,1 & 360,0 & 680,9 & 862,5 & 784,0 & 1043,0 & 703,0 \\
\hline
\end{tabular}

Fonte: (SILVA, C. P. C., 2013)

Figura 23 - Proporção (\%) (A) e intensidade (Média Geométrica) (B) da produção basal de peróxido de hidrogênio pelos neutrófilos sanguíneos $\mathrm{CH}_{138^{+}}$de vacas Holandesas no período de transição - São Paulo - 2013

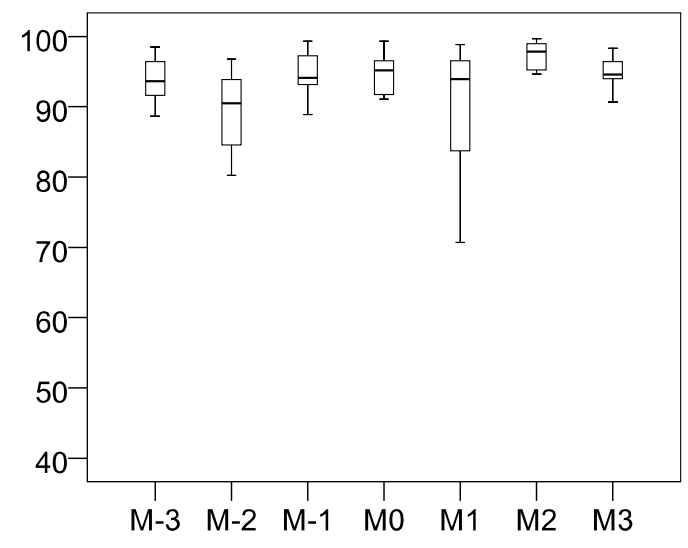

(A)

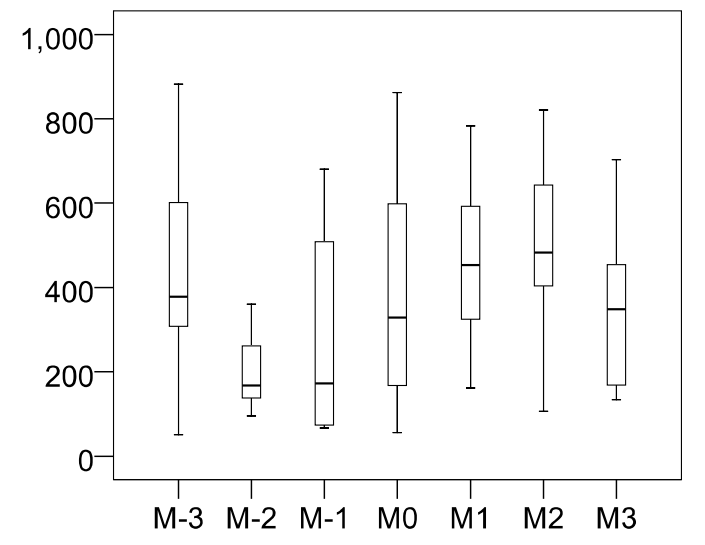

(B)

Fonte: (SILVA, C. P. C., 2013) 


\subsubsection{Produção de $\mathrm{H}_{2} \mathrm{O}_{2}$ pelos $\mathrm{CH}_{138^{+}}$estimulados com Staphylococcus aureus}

Ao avaliar a produção de $\mathrm{H}_{2} \mathrm{O}_{2}$ intracelular de $\mathrm{CH} 138^{+}$estimulados com bactérias, foi possível identificar duas populações apresentando baixa (low) e alta intensidade (high) de fluorescência, representadas pela média geométrica.

A proporção de $\mathrm{CH} 138^{+}$e a intensidade da produção de $\mathrm{H}_{2} \mathrm{O}_{2}$ após estímulo com Staphylococcus aureus estão apresentadas na tabela 8 e figuras 24 e 25.

As proporções de células $\mathrm{CH}_{138^{+}}$produzindo $\mathrm{H}_{2} \mathrm{O}_{2}$ low e high, respectivamente, foram de 46,4 e 38,5, 34,4 e 44,1, 35,0 e 31,6, 37,8 e 34,4, 36,0 e 29,2, 32,6 e 52,4, 30,1 e 42,2 \%. Não foi possível observar oscilações entre os momentos avaliados nas as populações low $(\mathrm{P}=0,170)$ e high ( $\mathrm{P}=0,124)$.

A intensidade de $\mathrm{H}_{2} \mathrm{O}_{2}$ produzida pelas populações $\mathrm{H}_{2} \mathrm{O}_{2}$ low e high, respectivamente, foi de 219,6 e 2600,$1 ; 132,0$ e 914,$2 ; 108,5$ e 819,$9 ; 157,1$ e 1731,$1 ; 124,2$ e 1919,9; 102,7 e 1954,0; 118,3 e 1223,1. Para a população low não foi possível detectar diferenças entre os momentos avaliados $(P=0,144)$. Para a população high, foi possível observar oscilações entre os momentos avaliados ( $P=0,000)$, sendo possível observar pico máximo no $M-3(219,57)$, observando que esse valor foi maior que os encontrados em M-2 (132) e M-1 (108,51), em seguida, os valores tornaram-se crescentes a partir do M0 $(157,10)$, mantendo-se elevados em M1 e M2, decrescendo em M3. Os valores obtidos no M0 foram maiores que os detectados em M-2 e M3; M1 e M2 apresentaram valores maiores que M-2, M-1 e M3. 
Tabela 8 - Produção de peróxido de hidrogênio pelos neutrófilos sanguíneos $\mathrm{CH} 138^{+}$ estimulados com Staphylococcus aureus em vacas Holandesas no período de transição - São Paulo - 2013

\begin{tabular}{|c|c|c|c|c|c|c|c|}
\hline \multicolumn{8}{|c|}{ Staphylococcus aureus - Low } \\
\hline \multicolumn{8}{|c|}{ Produção $\mathrm{H}_{2} \mathrm{O}_{2}(\%)$} \\
\hline & M-3 & M-2 & M-1 & MO & M1 & M2 & M3 \\
\hline Média & 43,7 & 29,8 & 35,9 & 34,8 & 39,4 & 32,4 & 34,4 \\
\hline Mediana & 46,4 & 34,4 & 35,0 & 37,8 & 36,0 & 32,6 & 30,1 \\
\hline Mínimo & 16,1 & 8,3 & 9,2 & 8,6 & 23,7 & 12,7 & 11,2 \\
\hline Máximo & 78,3 & 46,4 & 53,3 & 54,4 & 57,5 & 52,0 & 63,2 \\
\hline \multicolumn{8}{|c|}{ Intensidade Produção $\mathrm{H}_{2} \mathrm{O}_{2}$ (Média Geométrica) } \\
\hline Média & 216,3 & 136,9 & 117,0 & 176,1 & 167,3 & 145,7 & 127,2 \\
\hline Mediana & 219,6 & 132,0 & 108,5 & 157,1 & 124,2 & 102,7 & 118,3 \\
\hline Mínimo & 23,4 & 26,2 & 29,4 & 46,3 & 34,1 & 36,4 & 24,8 \\
\hline Máximo & 422,0 & 350,6 & 179,7 & 471,0 & 524,5 & 372,3 & 337,8 \\
\hline \multicolumn{8}{|c|}{ Staphylococcus aureus - High } \\
\hline \multicolumn{8}{|c|}{ Produção $\mathrm{H}_{2} \mathrm{O}_{2}(\%)$} \\
\hline & M-3 & M-2 & M-1 & MO & M1 & M2 & M3 \\
\hline Média & 38,5 & 44,4 & 31,2 & 44,4 & 30,3 & 54,5 & 42,3 \\
\hline Mediana & 38,4 & 44,1 & 31,6 & 34,4 & 29,2 & 52,4 & 42,2 \\
\hline Mínimo & 6,3 & 21,9 & 10,8 & 21,6 & 3,6 & 26,7 & 7,7 \\
\hline Máximo & 77,1 & 66,1 & 64,9 & 75,8 & 46,0 & 82,4 & 79,2 \\
\hline \multicolumn{8}{|c|}{ Intensidade Produção $\mathrm{H}_{2} \mathrm{O}_{2}$ (Média Geométrica) } \\
\hline Média & 2508,0 & 1029,0 & 1197,0 & 2216,0 & 2089,0 & 2126,0 & $\overline{1242}, 0$ \\
\hline Mediana & 2600,0 & 914,0 & 820,0 & 1731,0 & 1920,0 & 1954,0 & 1223,0 \\
\hline Mínimo & 552,0 & 220,0 & 252,0 & 672,0 & 1468,0 & 301,0 & 275,0 \\
\hline Máximo & 4312,0 & 2797,0 & 2901,0 & 4695,0 & 3571,0 & 3949,0 & 2474,0 \\
\hline
\end{tabular}

Fonte: (SILVA, C. P. C., 2013) 
Figura 24 - Produção de peróxido de hidrogênio pelos neutrófilos sanguíneos $\mathrm{CH} 138+$ (Low) estimulados com Staphylococcus aureus: (A) - Proporção (\%); (B) - Intensidade (Média Geométrica) em vacas Holandesas no período de transição - São Paulo 2013

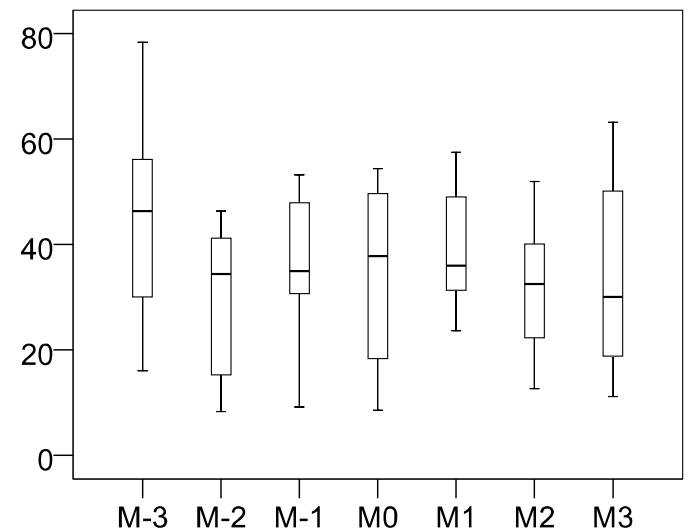

(A)

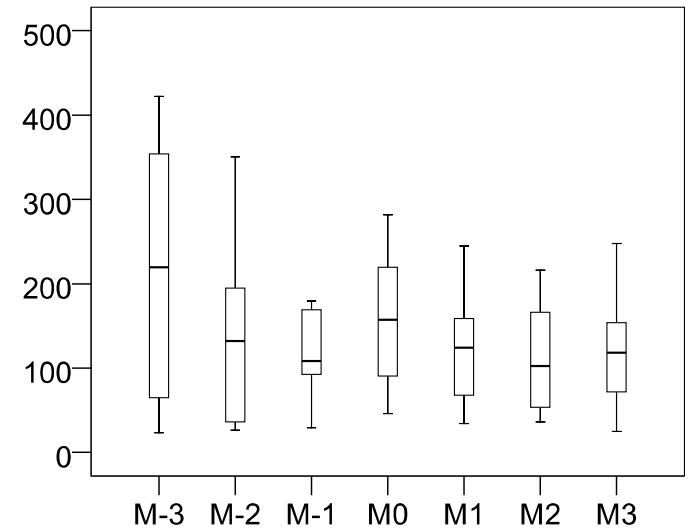

(B)

Fonte: (SILVA, C. P. C., 2013)

Figura 25 - Produção de peróxido de hidrogênio pelos neutrófilos sanguíneos $\mathrm{CH} 138+$ (High) estimulados com Staphylococcus aureus: (A) - Proporção (\%); (B) - Intensidade (Média Geométrica) em vacas Holandesas no período de transição - São Paulo 2013

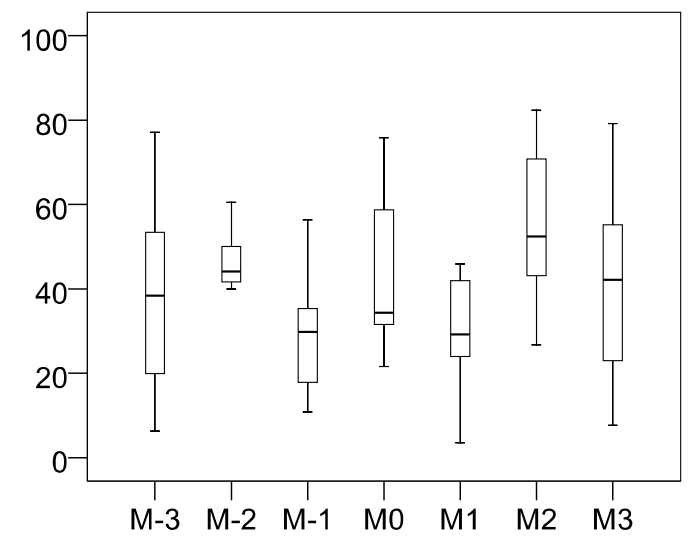

(A)

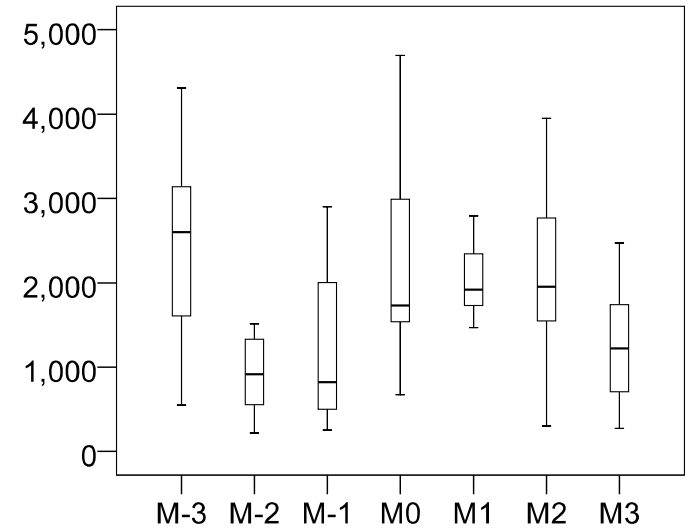

(B)

Fonte: (SILVA, C. P. C., 2013) 


\subsubsection{Produção de $\mathrm{H}_{2} \mathrm{O}_{2}$ pelos $\mathrm{CH}_{138^{+}}$estimulados com Escherichia coli}

A proporção de neutrófilos $\mathrm{CH}_{138^{+}}$e a intensidade da produção de $\mathrm{H}_{2} \mathrm{O}_{2}$ estimulados com Escherichia coli estão apresentadas na tabela 9 e figuras 26 e 27. As proporções de células $\mathrm{CH}_{138^{+}}$produzindo $\mathrm{H}_{2} \mathrm{O}_{2}$ high e low, respectivamente, foram de 67,7 e 26,4; 55,0 e 28,9; 57,0 e 21,6; 55,1 e 39,1; 33,0 e 29,2; 64,9 e 25,8; 57,0 e 22,7 da M-3 a M3. A população $\mathrm{H}_{2} \mathrm{O}_{2}$ high diminui do pré-parto até semana M1, em seguida, observou-se aumento dos valores. As células $\mathrm{H}_{2} \mathrm{O}_{2}$ low aumentaram no momento da parição observando-se retorno aos valores pré-parto nas semanas subseqüentes, porém não foram obtidas diferenças entre os tempos avaliados para a população high ( $\mathrm{P}=0,107)$ e low $(\mathrm{P}=0,961)$.

A intensidade de $\mathrm{H}_{2} \mathrm{O}_{2}$ produzido pelas populações $\mathrm{H}_{2} \mathrm{O}_{2}$ high e low, respectivamente, foi de 1098,9 e 134,9; 775,4 e 134,9; 599,7 e 89,0; 1681,2 e 174,1; 1251,3 e 67,9; 1722,0 e 85,3; 783,4 e 70,8 da M-3 a M3. Após análise estatística foi possível detectar oscilações entre os momentos estudados para a intensidade da produção de $\mathrm{H}_{2} \mathrm{O}_{2}$ pela população high $(\mathrm{P}=0,011)$ e não para a população low $(\mathrm{P}=0,109)$. A intensidade de $\mathrm{H}_{2} \mathrm{O}_{2}$ produzido pela população high foi diferente comparando-se o momento $\mathrm{M} 0$ em relação a M-3, M-2 e M1, M2 em relação a M-2 e $\mathrm{M} 1$; e M3 versus M-3, M0, M1 e M2. 
Tabela 9 - Produção de peróxido de hidrogênio pelos neutrófilos sanguíneos $\mathrm{CH} 138^{+}$ estimulados com Escherichia coli em vacas Holandesas no período de transição - São Paulo - 2013

\begin{tabular}{|c|c|c|c|c|c|c|c|}
\hline \multicolumn{8}{|c|}{ Escherichia coli-Low } \\
\hline \multicolumn{8}{|c|}{ Produção $\mathrm{H}_{2} \mathrm{O}_{2}(\%)$} \\
\hline & M-3 & M-2 & M-1 & M0 & M1 & M2 & M3 \\
\hline Média & 30,8 & 35,3 & 29,7 & 32,4 & 31,4 & 25,2 & 28,9 \\
\hline Mediana & 26,4 & 28,9 & 21,6 & 39,1 & 29,2 & 25,8 & 22,7 \\
\hline Mínimo & 3,3 & 7,4 & 6,5 & 9,3 & 9,6 & 5,7 & 11,3 \\
\hline Máximo & 65,4 & 76,6 & 60,5 & 55,0 & 56,5 & 47,4 & 62,9 \\
\hline \multicolumn{8}{|c|}{ Intensidade Produção $\mathrm{H}_{2} \mathrm{O}_{2}$ (Média Geométrica) } \\
\hline Média & 152,1 & 129,9 & 98,8 & 186,0 & 133,3 & 101,1 & 94,2 \\
\hline Mediana & 134,9 & 134,9 & 89,0 & 174,1 & 67,9 & 85,3 & 70,4 \\
\hline Mínimo & 46,9 & 28,0 & 24,7 & 53,7 & 42,1 & 16,2 & 28,6 \\
\hline Máximo & 324,4 & 313,2 & 281,5 & 373,2 & 350,0 & 228,8 & 301,2 \\
\hline \multicolumn{8}{|c|}{ Escherichia coli - High } \\
\hline \multicolumn{8}{|c|}{ Produção $\mathrm{H}_{2} \mathrm{O}_{2}(\%)$} \\
\hline & M-3 & M-2 & M-1 & MO & M1 & M2 & M3 \\
\hline Média & 58,3 & 47,2 & 51,7 & 52,3 & 36,9 & 62,0 & 53,2 \\
\hline Mediana & 67,7 & 55,0 & 57,0 & 55,1 & 33,0 & 64,9 & 57,0 \\
\hline Mínimo & 13,5 & 17,1 & 16,1 & 16,8 & 13,3 & 32,2 & 11,2 \\
\hline Máximo & 92,1 & 77,1 & 80,8 & 77,5 & 58,5 & 78,9 & 79,0 \\
\hline \multicolumn{8}{|c|}{ Intensidade Produção $\mathrm{H}_{2} \mathrm{O}_{2}$ (Média Geométrica) } \\
\hline Média & 1176,0 & 829,0 & 1017,0 & 2078,0 & 1140,0 & 1639,0 & 811,0 \\
\hline Mediana & 1099,0 & 775,0 & 600,0 & 1681,0 & 1251,0 & 1722,0 & 783,0 \\
\hline Mínimo & 486,0 & 248,0 & 156,0 & 498,0 & 586,0 & 120,0 & 310,0 \\
\hline Máximo & 1865,0 & 1176,0 & 2564,0 & 3882,0 & 1665,0 & 2903,0 & 1566,0 \\
\hline
\end{tabular}


Figura 26 - Produção de peróxido de hidrogênio pelos neutrófilos sanguíneos $\mathrm{CH} 138+$ (Low) estimulados com Escherichia coli: (A) - Proporção (\%); (B) - Intensidade (Média Geométrica) em vacas Holandesas no período de transição - São Paulo - 2013

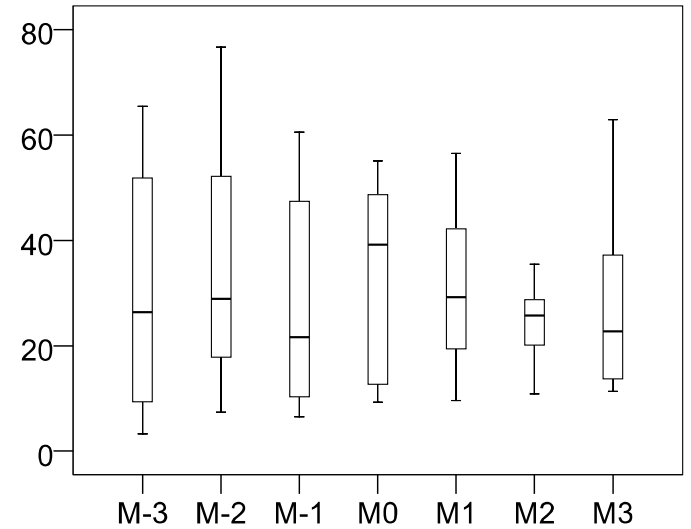

(A)

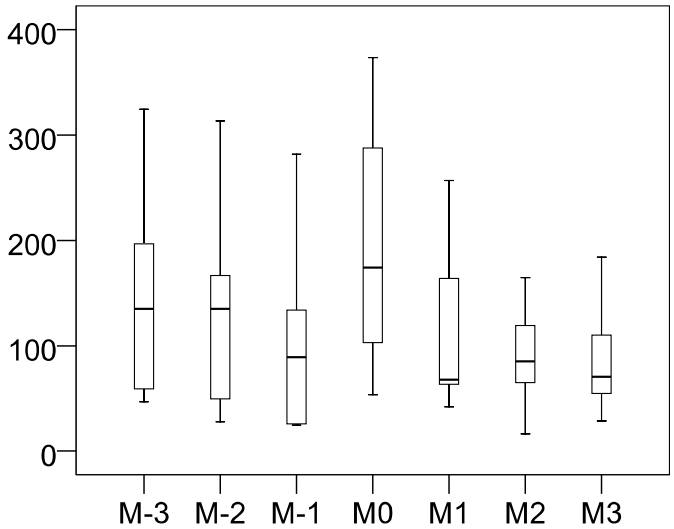

(B)

Fonte: (SILVA, C. P. C., 2013)

Figura 27 - Produção de peróxido de hidrogênio pelos neutrófilos sanguíneos $\mathrm{CH} 138+$ (High) estimulados com Escherichia coli: (A) - Proporção (\%); (B) - Intensidade (Média Geométrica) em vacas Holandesas no período de transição - São Paulo - 2013

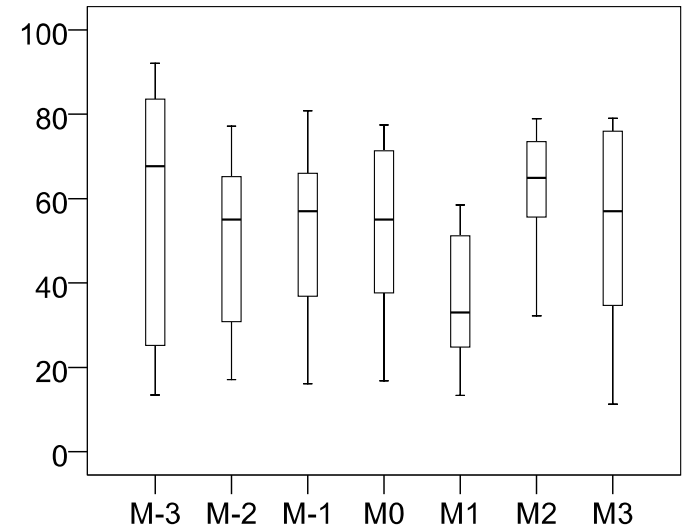

(A)

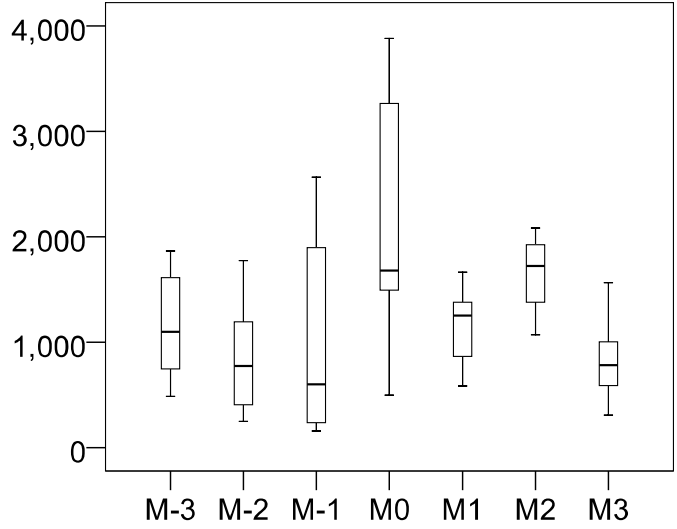

(B)

Fonte: (SILVA, C. P. C., 2013) 


\subsection{RESPOSTA IMUNE INATA DA GLÂNDULA MAMÁRIA}

\subsubsection{Contagem de células somáticas}

Os resultados obtidos na CCS nas amostras de secreção mamária em vacas Holandesas no pós-parto estão dispostos na tabela 10 e figura 28. A partir da análise estatística realizada, foi possível verificar oscilações entre os momentos M-3 a M3 $(P=0.000)$. Foram detectadas diferenças entre todos os momentos avaliados, exceto entre M1 e M2, que apresentaram CCS semelhantes ( $P=0,303)$.

A comparação entre a CCS de mamas infectadas e não-infectadas foi realizada nos momentos $\mathrm{M} 0, \mathrm{M} 1$ e $\mathrm{M} 3$, no momento $\mathrm{M} 2$ observou-se baixa taxa de infecção mamária $(7,7 \%)$, impossibilitando a comparação entre grupos (Tabela 3). Não foram encontradas diferenças entre a CCS da secreção mamária de vacas infectadas e não infectadas (Tabela 11). 
Tabela 10 - Contagem de células somáticas na secreção mamária de vacas Holandesas no pós-parto - São Paulo - 2013

\begin{tabular}{c|cccc}
\hline \multicolumn{7}{l}{ CCS } \\
\hline Parâmetros/Momentos & M0 & M1 & M2 & M3 \\
\hline Medianas $\left(\times 10^{6}\right.$ células $\left./ \mathrm{mL}\right)$ & 1,5 & 0,2 & 0,2 & 0,07 \\
Mínino $\left(\times 10^{6}\right.$ células $\left./ \mathrm{mL}\right)$ & 0,3 & 0,03 & 0,03 & 0,1 \\
Máximo $\left(\times 10^{6}\right.$ células $\left./ \mathrm{mL}\right)$ & 67,8 & 10,8 & 28,5 & 23,3
\end{tabular}

Fonte: (SILVA, C. P. C., 2013)

Tabela 11 - Contagem de células somáticas na secreção mamária em vacas Holandesas no pós-parto imediato, de acordo com o status infeccioso da glândula mamária, São Paulo - 2013

\begin{tabular}{c|c|ccc}
\hline \multicolumn{2}{c|}{ Parâmetros/Momentos } & Infecção (+) & Infecção (-) & Significância \\
\hline M0 & Medianas & 1,7 & 1,3 & 0,4122 \\
& Mínino & 0,3 & 0,3 & \\
& Máximo & 31,9 & 67,9 & \\
\hline M1 & Medianas & 0,2 & 0,3 & 0,9643 \\
& Mínino & 0,03 & 0,03 & \\
& Máximo & 10,9 & 10,3 & \\
\hline M3 & Medianas & 0,05 & 0,07 & 0,9037 \\
& Mínino & 0,02 & 0,01 & \\
& Máximo & 3,9 & 23,3 & \\
& & & &
\end{tabular}

Fonte: (SILVA, C. P. C., 2013)

Figura 28 - Mediana da contagem de células somáticas no colostro e leite de vacas Holandesas no pós-parto - São Paulo - 2013

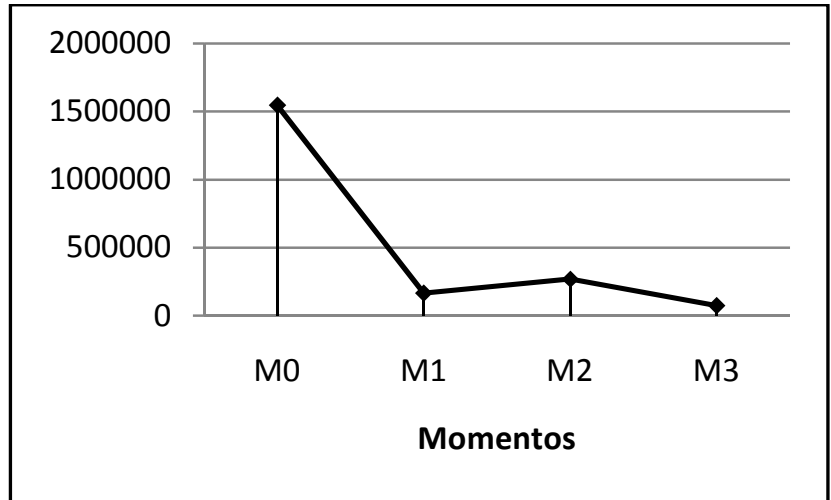

Fonte: (SILVA, C. P. C., 2013) 


\subsubsection{Viabilidade Celular}

A viabilidade (\%) das células do colostro (M0) e leite no pós-parto (M1 ao M3) está disposta na tabela 12 e figura 29. Foi possível detectar variações durante o período de estudo $(P=0,016)$. A menor proporção de células viáveis foi observada no colostro (32\%), com aumento desses valores em M1 até atingir pico máximo no M2M3. A viabilidade celular no M0 foi diferente da obtida em M2 e M3; e M1 em relação a M3.

\begin{tabular}{lcccc} 
Tabela 12 - $\begin{array}{c}\text { Proporção (\%) de células viáveis } \\
\text { obtidas a partir do colostro e leite de } \\
\text { vacas Holandesas no pós-parto - } \\
\text { São Paulo - 2013 }\end{array}$ \\
\hline \multicolumn{5}{c}{ Viabilidade (\%) } \\
\hline M0 & M1 & M2 & M3 \\
Media & 35,3 & 45,8 & 53,4 & 57,1 \\
Mínimo & 32 & 42 & 54,5 & 52,5 \\
Máximo & 0 & 3 & 0 & 0 \\
\hline
\end{tabular}

Fonte: (SILVA, C. P. C., 2013)

Figura 29 - Proporção (\%) de células totais viáveis, obtidas no colostro e leite de vacas Holandesas no pós-parto - São Paulo 2013

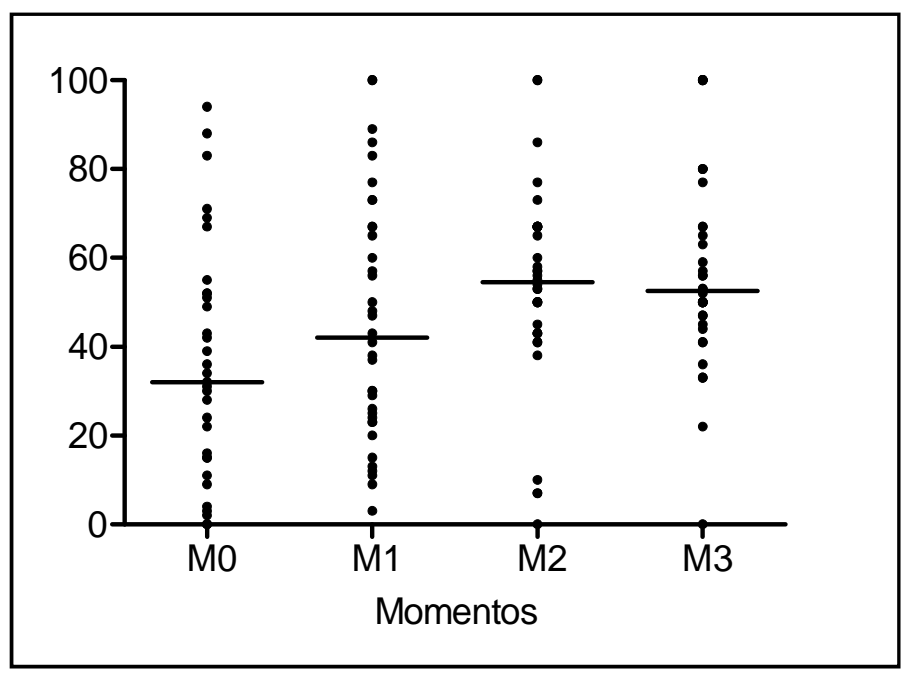

Fonte: (SILVA, C. P. C., 2013) 


\subsubsection{Concentração de células viáveis}

Na primeira etapa de separação das células totais do colostro, as células

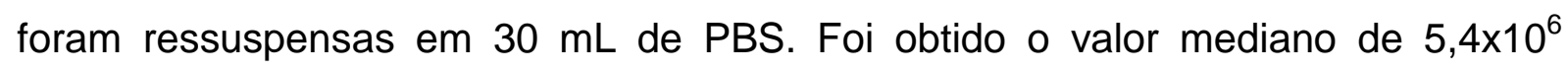
células totais $/ \mathrm{mL}$, multiplicado pelo volume da suspensão celular $(30 \mathrm{~mL})$, resultou no rendimento celular de $16,2 \times 10^{7}$ células totais. Após a separação dos PMN por gradiente de densidade, obteve-se concentração celular de 7,05 x $10^{6}$ neutrófilos viáveis/mL, multiplicado pelo volume da suspensão de PMN (1mL), resultou no rendimento celular de $7,05 \times 10^{6}$ neutrófilos viáveis.

As concentrações de células totais viáveis $/ \mathrm{mL}$ leite no pós-parto estão dispostas na tabela 13.

As amostras foram consideradas como adequadas ou inadequadas para a inclusão nos ensaios de avaliação funcional dos neutrófilos $\mathrm{CH} 138^{+}$. O critério adotado para inclusão das amostras foi número de PMN do colostro ou células viáveis do leite equivalente a $1,2 \times 10^{6}$ (Tabela 14). 
Tabela 13 - Concentração de células totais viáveis observadas no leite de vacas Holandesas no pós-parto - São Paulo - 2013

\begin{tabular}{c|ccc}
\hline Momentos & M1 & M2 & M3 \\
\hline Mediana $\left(\times 10^{6}\right.$ células totais $\left./ \mathrm{mL}\right)$ & 1,0 & 1,1 & 0,45 \\
Mínino $\left(\times 10^{6}\right.$ células totais $\left./ \mathrm{mL}\right)$ & 0,1 & 0 & 0 \\
Máximo $\left(\times 10^{6}\right.$ células totais $\left./ \mathrm{mL}\right)$ & 116,1 & 629,0 & 524,4 \\
\hline
\end{tabular}

Fonte: (SILVA, C. P. C., 2013)

Tabela 14 - Número de amostras (N.) adequadas e inadequadas para a inclusão nos ensaios de proporção e função de neutrófilos em vacas Holandesas no pós-parto - São Paulo - 2013

\begin{tabular}{c|cc|cc|c}
\hline \multicolumn{7}{c}{ Adequação Amostral para Ensaios Função PMN } \\
\hline \multirow{2}{*}{ Momentos } & \multicolumn{2}{|c|}{ Adequadas } & \multicolumn{1}{l}{ Inadequadas } & Total (n) \\
\cline { 2 - 6 } & $\mathrm{N}$. & $\%$ & $\mathrm{~N}$. & $\%$ & \\
\hline M0 & 25 & 73,5 & 9 & 26,5 & 34 \\
M1 & 17 & 47,2 & 19 & 52,7 & 36 \\
M2 & 19 & 52,7 & 17 & 47,2 & 36 \\
M3 & 8 & 22,2 & 28 & 77,8 & 36 \\
Total & 69 & & 73 & & 142 \\
\hline
\end{tabular}

Fonte: (SILVA, C. P. C., 2013)

4.5.4 Pureza da suspensão de PMN do colostro - Proporção $\mathrm{CH} 138^{+}$

Apesar do uso de Histopaque 1083 para separação dos PMN dentre as células totais do colostro, foi possível observar valor mediano de $\mathrm{CH} 138+$ equivalente a $10,76 \%$ da suspensão celular de PMN separada por gradiente de densidade. 
4.5.5 Proporção de neutrófilos $\mathrm{CH} 138^{+}$do leite

As proporções de células $\mathrm{CH}_{138^{+}}$presentes no leite do $\mathrm{M} 1$ ao $\mathrm{M} 3$ estão apresentadas na tabela 15 e figura 30. Não foi possível obter diferença estatística comparando os tempos estudados $(P=0,753)$.

\begin{tabular}{lrrr} 
Tabela $15-\begin{array}{l}\text { Proporção (\%) de neutrófilos } \\
\text { presentes no leite de vacas Holandesas } \\
\text { no pós-parto - São Paulo - 2013 }\end{array}$ \\
\hline \multicolumn{4}{c}{ Neutrófilos $\mathrm{CH} 138^{+}$} \\
\hline M1 & M2 & M3 \\
Média & 37,0 & 25,5 & 52,9 \\
Mediana & 34,4 & 10,5 & 59,5 \\
Mínimo & 4,6 & 1,4 & 7,3 \\
Máximo & 89,2 & 97,1 & 89,5 \\
\hline
\end{tabular}

Fonte: (SILVA, C. P. C., 2013)

Figura 30 - Proporção (\%) de neutrófilos $\mathrm{CH}_{138^{+}}$ presentes no leite de vacas Holandesas no pós-parto - São Paulo $-2013$

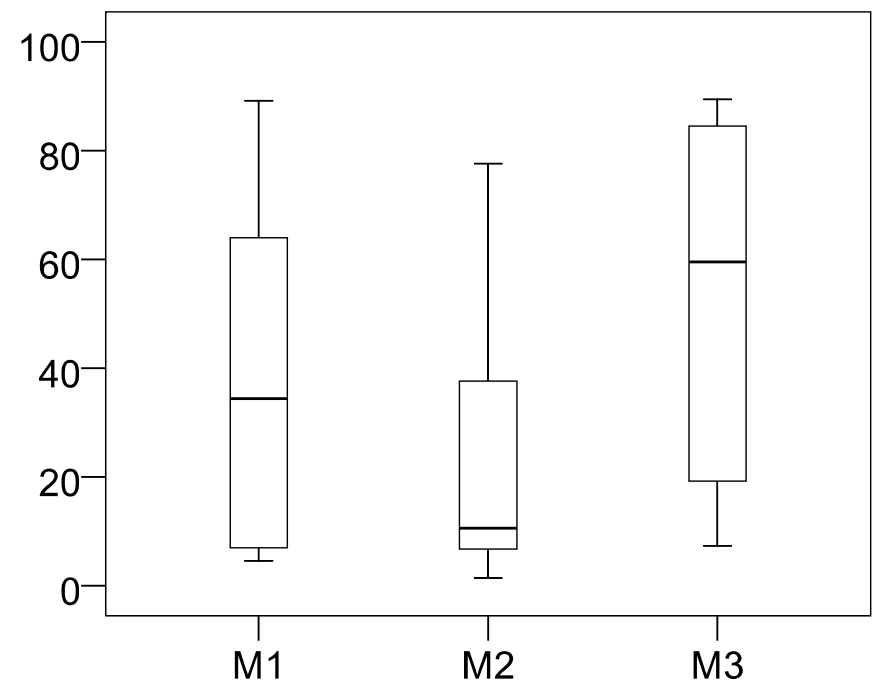

Fonte: (SILVA, C. P. C., 2013) 
4.5.6 Fagocitose de bactérias pelos neutrófilos $\mathrm{CH} 138^{+}$

\subsubsection{Fagocitose de Staphylococcus aureus}

A proporção (\%) e intensidade da fagocitose de neutrófilos $\mathrm{CH}_{138^{+}}$da secreção mamária após estimulo bacteriano, estão apresentadas na tabela $16 \mathrm{e}$ figura 31.

A porcentagem de neutrófilos $\mathrm{CH}_{138^{+}}$que fagocitaram $S$. aureus, nos momentos M0 a M3, respectivamente, foram de 46,2, 59,5, 56,2 e 55,5, apesar de não ter sido possível observar diferenças estatísticas ( $P=0,187)$, ocorreu acréscimo nos valores comparando-se o pós-parto imediato (M0) com as semanas pós-parto. A intensidade da fagocitose (Média Geométrica) obtida foi de 28,6; 32,8; 46,0 e 42,9 nas semanas $M 0$ a $M 3$, respectivamente, sendo possível observar aumento dos valores obtidos do M0 ao M2-M3, porém sem que fossem obtidas diferenças estatísticas $(P=0,44)$. 
Tabela 16 - Proporção (\%) e intensidade da fagocitose de Staphylococcus aureus (Média Geométrica) pelos neutrófilos $\mathrm{CH} 138^{+}$do colostro e leite de vacas Holandesas no pós-parto - São Paulo - 2013

\begin{tabular}{|c|c|c|c|c|}
\hline \multicolumn{5}{|c|}{ Staphylococcus aureus } \\
\hline \multicolumn{5}{|c|}{ Fagocitose (\%) } \\
\hline & MO & M1 & M2 & M3 \\
\hline Média & 45,18 & 50,84 & 56,57 & 58,92 \\
\hline Mediana & 46,21 & 59,50 & 56,17 & 55,48 \\
\hline Mínimo & 2,95 & 2,03 & 25,74 & 47,80 \\
\hline Máximo & 92,17 & 84,68 & 88,67 & 74,15 \\
\hline \multicolumn{5}{|c|}{ Intensidade da fagocitose (Média Geométrica) } \\
\hline Média & 34,30 & 33,78 & 43,88 & 47,34 \\
\hline Mediana & 28,58 & 32,76 & 46,02 & 42,90 \\
\hline Mínimo & 16,22 & 12,60 & 4,56 & 15,00 \\
\hline Máximo & 93,74 & 66,19 & 91,22 & 96,25 \\
\hline
\end{tabular}

Fonte: (SILVA, C. P. C., 2013)

Figura 31 - Proporção (\%) (A) e intensidade da fagocitose (B) de Staphylococcus aureus pelos neutrófilos $\mathrm{CH}_{138^{+}}$do colostro e leite de vacas Holandesas no período de transição - São Paulo - 2013

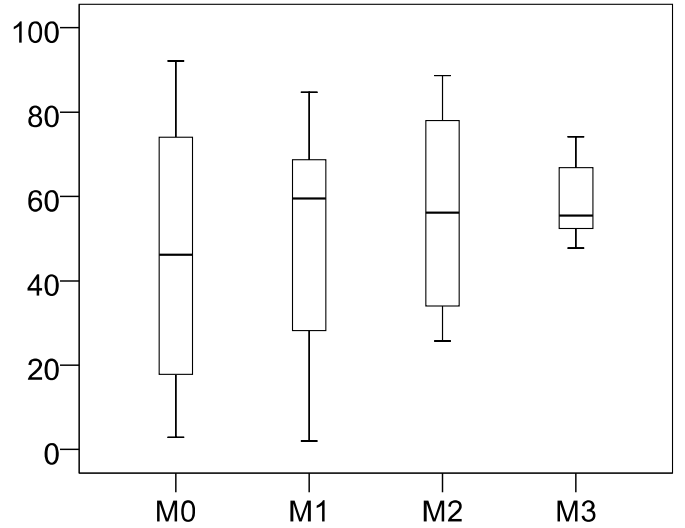

(A)

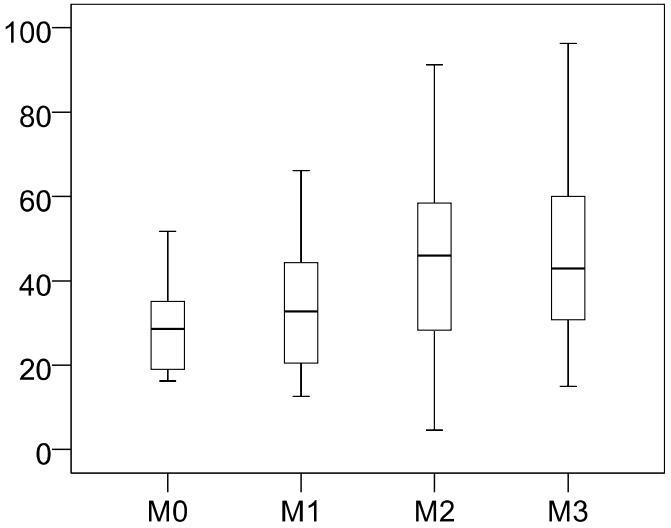

(B)

Fonte: (SILVA, C. P. C., 2013) 


\subsubsection{Fagocitose de Escherichia coli}

A proporção de neutrófilos $\mathrm{CH}_{138^{+}}$que realizaram a fagocitose após estímulo com Escherichia coli foi de 59,4, 67,8, 73,2 e 58,4, nos momento M0 a M3, respectivamente, observando aumento da fagocitose (\%) do $\mathrm{M0}$ ao $\mathrm{M} 2$, ocorrendo decréscimo no $M 3$, porém não foram detectadas diferenças $(P=0,145)$. $A$ intensidade da fagocitose Escherichia coli foi de 28,8, 33,5, 63,4 e 61,9, nos momentos M0 a M3, notando-se um aumento nos valores do $M 0$ ao $M 3$, porém não foi possível detectar diferenças entre os momentos ( $P=0,896)$ (Tabela 17 e Figura 32). 
Tabela 17 - Proporção (\%) e intensidade da fagocitose (Média Geométrica) de Escherichia coli pelos neutrófilos $\mathrm{CH} 138^{+}$do colostro e leite de vacas Holandesas no período de transição - São Paulo - 2013

\begin{tabular}{lrrrr}
\hline \multicolumn{5}{c}{ Escherichia coli } \\
\hline Média & Fagocitose (\%) \\
Mediana & 48,38 & 57,56 & 66,2 & 59,3 \\
Mínimo & 59,45 & 67,78 & 73,2 & 58,4 \\
Máximo & 4,08 & 1,55 & 24,4 & 39,6 \\
& 91,02 & 84,49 & 91 & 84,3 \\
\hline Média & Intensidade da fagocitose (Média Geométrica) \\
Mediana & 41,9 & 38,9 & 64,8 & 64,4 \\
Mínimo & 28,8 & 33,5 & 63,4 & 61,9 \\
Máximo & 16,6 & 15,1 & 11,4 & 28,8 \\
& 183,3 & 84,4 & 119,2 & 140,7 \\
\hline
\end{tabular}

Fonte: (SILVA, C. P. C., 2013)

Figura 32 - Proporção (\%) (A) e intensidade da fagocitose (B) de Escherichia coli pelos neutrófilos $\mathrm{CH} 138^{+}$do colostro e leite de vacas Holandesas no período de transição - São Paulo - 2013

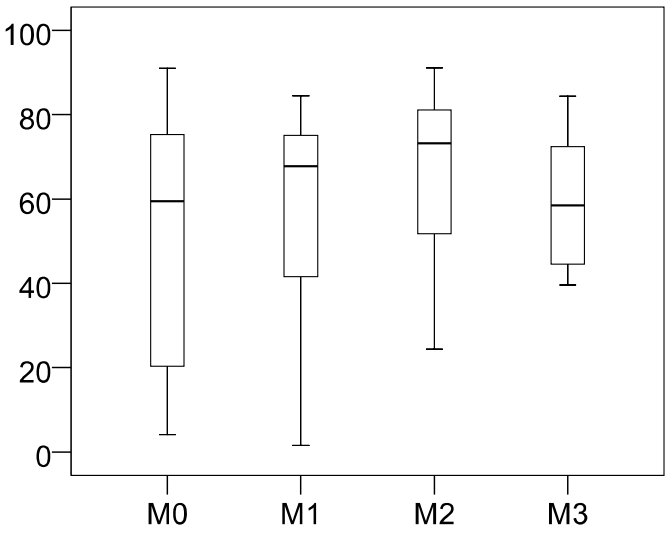

(A)

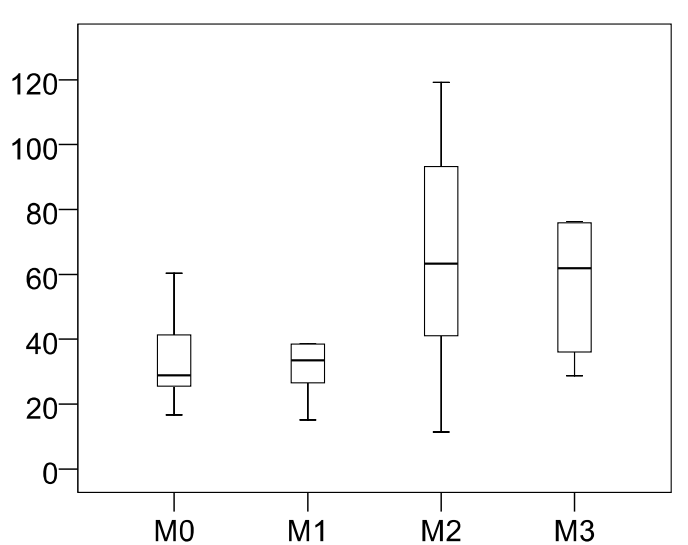

(B)

Fonte: (SILVA, C. P. C., 2013) 
4.5.7 Produção intracelular de peróxido de hidrogênio $\left(\mathrm{H}_{2} \mathrm{O}_{2}\right)$ pelos neutrófilos $\mathrm{CH} 138^{+}$:

\subsubsection{Produção de $\mathrm{H}_{2} \mathrm{O}_{2}$ pelos $\mathrm{CH}_{138^{+}}$Basal}

A tabela 18 e figura 33 apresentam a proporção e intensidade da fagocitose das células $\mathrm{CH}_{138^{+}}$da secreção mamária, na ausência de estímulo bacteriano (basal).

A proporção de células $\mathrm{CH} 138^{+}$produzindo $\mathrm{H}_{2} \mathrm{O}_{2}$ basal foi de 76,$9 ; 62,1 ; 77,7$; 82,9 nos momentos M0 a M3. Não foram detectadas diferenças entre os momentos $(\mathrm{P}=0,552)$. A intensidade da produção basal de $\mathrm{H}_{2} \mathrm{O}_{2}$ basal foi de 109,8, 78,3; 70,7 e 157,6 em todos os momentos avaliados, e observou-se diminuição progressiva dos valores do momento $M 0$ até o $M 2$, com aumento subsequente (M3), porém não foi possível obter diferenças estatísticas $(P=0,127)$. 
Tabela 18 - Produção basal de peróxido de hidrogênio pelos neutrófilos $\mathrm{CH}_{138^{+}}$do colostro e leite de vacas Holandesas no período de transição - São Paulo 2013

\begin{tabular}{lccrr}
\hline \multicolumn{5}{c}{ Produção $\mathrm{H}_{2} \mathrm{O}_{2}-$ basal (\%) } \\
\hline Módia & M0 & M1 & M2 & M3 \\
Mediana & 65,4 & 64,5 & 76,55 & 80,79 \\
Mínimo & 76,9 & 62,1 & 77,74 & 82,87 \\
Máximo & 9,6 & 13,9 & 36,01 & 59,56 \\
\hline Intensidade da Produção de $\mathrm{H}_{2} \mathrm{O}_{2}$ & - basal (Média Geométrica) \\
\hline Média & 217,9 & 119,3 & 145,8 & 166,1 \\
Mediana & 109,8 & 78,3 & 70,7 & 157,6 \\
Mínimo & 20,3 & 24,0 & 30,3 & 92,5 \\
Máximo & 971,2 & 299,1 & 993,7 & 284,8 \\
\hline
\end{tabular}

Fonte: (SILVA, C. P. C., 2013)

Figura 33 - Proporção (\%) (A) e intensidade (Média Geométrica) (B) da produção basal de peróxido de hidrogênio pelos neutrófilos $\mathrm{CH}_{138^{+}}$do colostro e leite de vacas Holandesas no período de transição - São Paulo - 2013

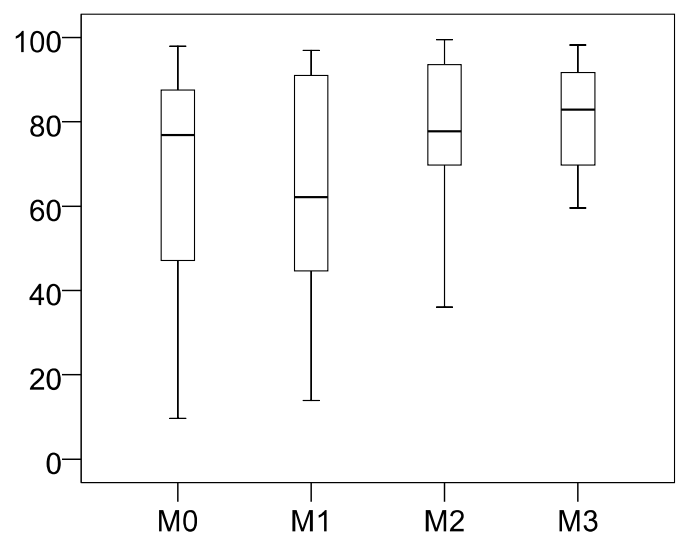

(A)

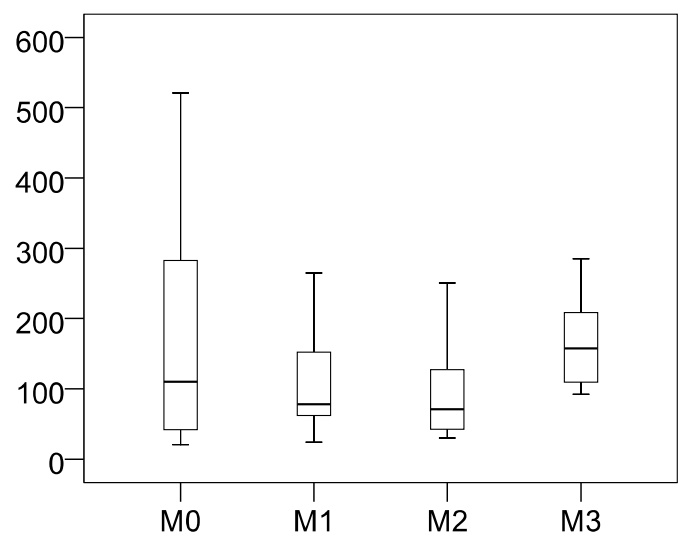

(B)

Fonte: (SILVA, C. P. C., 2013) 


\subsubsection{Produção de $\mathrm{H}_{2} \mathrm{O}_{2}$ pelos $\mathrm{CH}_{138^{+}}$estimulados com Staphylococcus aureus}

A avaliação da produção de $\mathrm{H}_{2} \mathrm{O}_{2}$ intracelular pelos neutrófilos $\mathrm{CH}_{138^{+}}$ obtidos a partir do colostro e leite bovino permitiu a separação dessas células em duas populações, que apresentaram baixa (low) e alta intensidade (high) de fluorescência, representadas pelas suas médias geométricas, semelhante ao relatado para o sangue. A proporção de $\mathrm{CH}_{138^{+}}$e a intensidade da produção de $\mathrm{H}_{2} \mathrm{O}_{2}$ das populações low e high após estímulo com a bactéria Staphylococcus aureus estão apresentadas na tabela 19 e figuras 34 e 35 .

As proporções de células $\mathrm{CH}_{138^{+}}$produzindo $\mathrm{H}_{2} \mathrm{O}_{2}$ high e low, respectivamente, foram de 6,3 e 11,7, 3,10 e 18,7, 5,7 e 41,1, 22,5 e 37,5 nas semanas M0 a M3. Após análise estatística foi possível observar oscilações entre os momentos estudados apenas para a população $\mathrm{CH} 138^{+}$high no teste de Friedman $(\mathrm{P}=0,019)$, porém essa diferença foi excluída após o teste de Wilcoxon associado ao Bonferroni. Não foi possível detectar variações na $\mathrm{H}_{2} \mathrm{O}_{2}$ low $(\mathrm{P}=0,960)$.

A intensidade da produção de $\mathrm{H}_{2} \mathrm{O}_{2}$ pelas populações denominadas high e low foram, respectivamente, de 788,9 e 39,4; 1305,2 e 40,4; 893,4 e 46,0; 889,2 e 55,1 em todos os momentos avaliados. Não foi possível observar diferenças entre os momentos na intensidade da produção de $\mathrm{H}_{2} \mathrm{O}_{2}$ da população high $(\mathrm{P}=0,145)$ e low $(\mathrm{P}=0,960)$, porém pode-se observar aumento da semana M0 para a semana M1 com posterior diminuição dos valores obtidos para a intensidade high nas semanas M2 e M3. Em relação à população low observou-se aumento progressivo dos valores obtidos na intensidade da produção de $\mathrm{H}_{2} \mathrm{O}_{2}$ entre as semanas $\mathrm{MO}$ a M3. 
Tabela 19 - Produção de peróxido de hidrogênio, com estímulo da Staphylococcus aureus, pelos neutrófilos $\mathrm{CH} 138^{+}$do colostro e leite de vacas Holandesas no pós-parto - São Paulo - 2013

\begin{tabular}{lrrrr|cccc}
\hline \multicolumn{7}{c}{ Staphylococcus aureus - Low } & \multicolumn{7}{c}{ Staphylococcus aureus - High } \\
\hline \multicolumn{10}{c}{ M0 } & M1 & M2 & M3 & M0 & M1 & M2 & M3 \\
Média & 23,5 & 35,8 & 43,1 & 36,2 & 8,3 & 5,16 & 15,04 & 19,73 \\
Mediana & 11,7 & 18,7 & 41,1 & 37,5 & 6,34 & 3,1 & 5,56 & 22,5 \\
Mínimo & 1,1 & 2,0 & 2,1 & 16,2 & 0,38 & 0,05 & 0 & 4,82 \\
Máximo & 80,3 & 87,3 & 90,8 & 57,6 & 59,28 & 18,92 & 60,23 & 32,19 \\
\hline \multicolumn{7}{c}{ Intensidade Produção } & $\mathrm{H}_{2} \mathrm{O}_{2}$ (Média Geométrica) \\
\hline Média & 89,1 & 1149,4 & 79,6 & 70,7 & 1243,1 & 1457,2 & 1034,3 & 870,1 \\
Mediana & 39,4 & 40,4 & 46,0 & 55,1 & 788,9 & 1305,2 & 893,3 & 889,2 \\
Mínimo & 14,6 & 17,8 & 15,1 & 28,1 & 58,5 & 115,0 & 31,5 & 349,9 \\
Máximo & 421,8 & 18304,0 & 387,5 & 189,8 & 4066,3 & 3098,0 & 2180,9 & 1288,7 \\
\hline Fonte: (SILVA, C. P. C., 2013)
\end{tabular}


Figura 34 - Produção de peróxido de hidrogênio pelos neutrófilos $\mathrm{CH} 138+$ (Low) do colostro e leite, estimulados com Staphylococcus aureus: (A) - Proporção (\%); (B) Intensidade (Média Geométrica) em vacas Holandesas no período de transição São Paulo - 2013

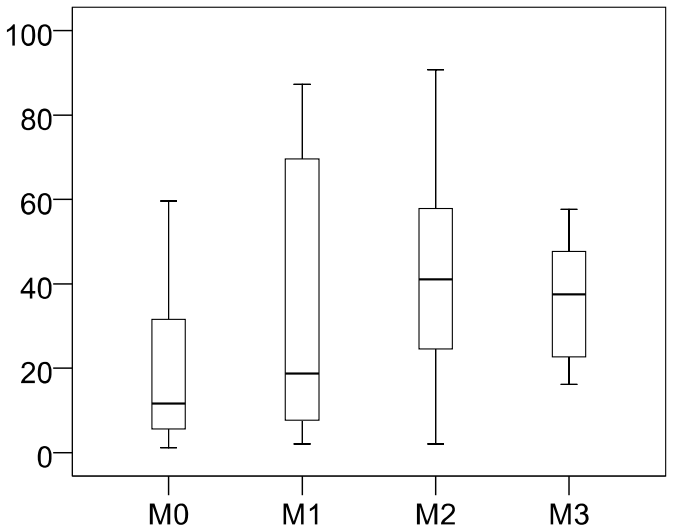

(A)

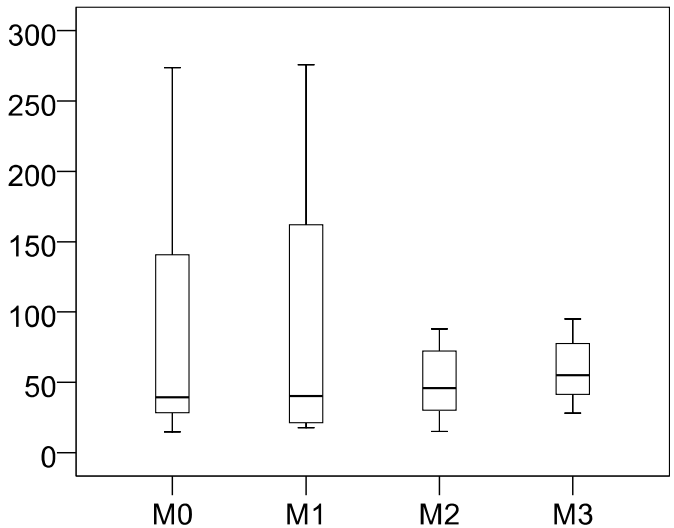

(B)

Fonte: (SILVA, C. P. C., 2013)

Figura 35 - Produção de peróxido de hidrogênio pelos neutrófilos $\mathrm{CH} 138+($ High) do colostro e leite, estimulados com Staphylococcus aureus: (A) - Proporção (\%); (B) Intensidade (Média Geométrica) em vacas Holandesas no período de transição São Paulo - 2013

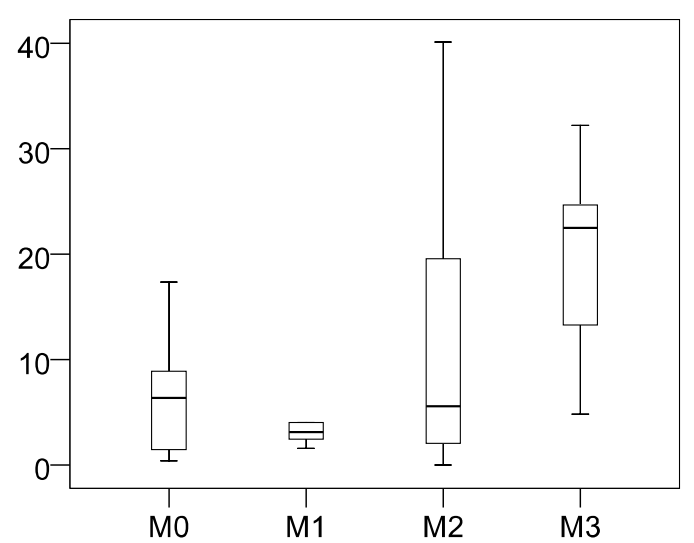

(A)

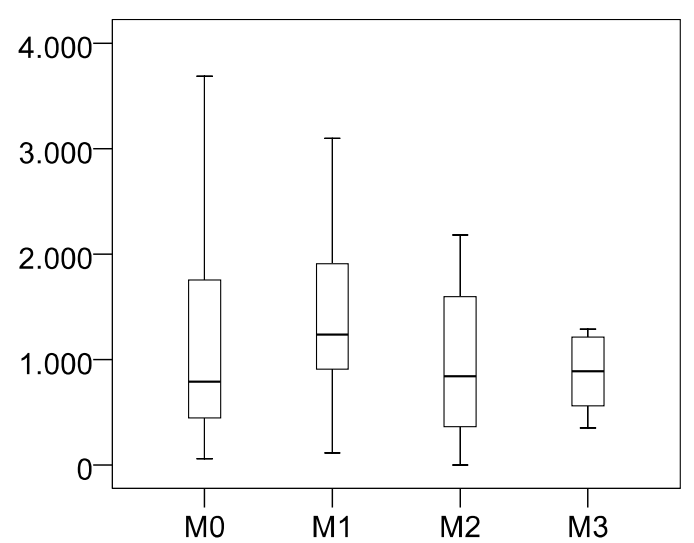

(B)

Fonte: (SILVA, C. P. C., 2013) 


\subsubsection{Produção de $\mathrm{H}_{2} \mathrm{O}_{2}$ pelos $\mathrm{CH}_{138^{+}}$estimulados com Escherichia coli}

A proporção e intensidade da produção de peróxido de hidrogênio $\left(\mathrm{H}_{2} \mathrm{O}_{2}\right)$ pelas populações denominadas low e high após estímulo com Escherichia coli estão apresentadas na tabela 20 e figuras 36 e 37.

A proporção (\%) de células $\mathrm{CH}_{138^{+}}$low produzindo $\mathrm{H}_{2} \mathrm{O}_{2}$ foi de 10,$7 ; 20,01$; 36,4 e 24,02, nas semanas M0 a M3, respectivamente. Não foi possível detectar oscilações entre as semanas avaliadas $(\mathrm{P}=0,656)$. A intensidade da produção de $\mathrm{H}_{2} \mathrm{O}_{2}$ low foi de 51,$62 ; 46,84 ; 45,23$ e 62,48 , nas semanas $\mathrm{M0}$ a $\mathrm{M} 3$, respectivamente, sendo possível observar um decréscimo progressivo nos valores obtidos entre a semana $M 0$ a $M 2$ com aumento subseqüente na $M 3$, porém não foram observadas diferenças entre os tempos avaliados $(P=0,497)$.

A proporção (\%) de células $\mathrm{CH} 138^{+}$denominadas high nos momentos $\mathrm{M0}$ a M3 foi de 4,32; 4,11; 3,95 e 19,89, respectivamente. Não foi possível detectar variações no período de estudo $(\mathrm{P}=0,077)$, apesar do pico máximo no $M 3$. A intensidade da produção de $\mathrm{H}_{2} \mathrm{O}_{2}$ pela população high foi de 753,$42 ; 1139,50$; 820,75 e 1016,80, nos momentos M0 a M3 respectivamente. Apesar das oscilações encontradas, não foi possível determinar diferença estatística $(P=0,326)$.

Tabela 20 - Produção de peróxido de hidrogênio, com estímulo da Escherichia coli, pelos neutrófilos $\mathrm{CH}_{138^{+}}$do colostro e leite de vacas Holandesas no pós-parto São Paulo - 2013

\begin{tabular}{lrrrr|rrrr}
\hline & Escherichia coli - Low & \multicolumn{7}{c}{ Escherichia coli - High } \\
\hline \multicolumn{1}{c}{ M0 } & M1 & M2 & M3 & M0 & M1 & M2 & M3 \\
Média & 20,8 & 26,6 & 44,2 & 25,3 & 6,0 & 5,5 & 7,7 & 20,3 \\
ediana & 10,7 & 20,0 & 36,4 & 24,0 & 4,3 & 4,1 & 3,9 & 19,89 \\
Mínimo & 1,9 & 0,9 & 5,1 & 6,1 & 0,5 & 0,0 & 0,0 & 3,35 \\
Máximo & 76,5 & 89,7 & 95,3 & 52,0 & 23,7 & 20,6 & 34,6 & 42,06 \\
\hline \multicolumn{7}{c}{ Intensidade Produção } & $\mathrm{H}_{2} \mathrm{O}_{2}$ (Média Geométrica) \\
\hline Média & 91,2 & 66,7 & 66,8 & 74,1 & 1307,8 & 1413,9 & 981,2 & 895,0 \\
Mediana & 51,6 & 46,8 & 45,2 & 62,5 & 753,4 & 1139,5 & 820,8 & 1016,8 \\
Mínimo & 17,3 & 20,1 & 17,0 & 30,7 & 189,9 & 63,3 & 0,0 & 259,9 \\
Máximo & 350,9 & 205,5 & 419,5 & 134,8 & 455,1 & 3203,7 & 2464,4 & 1466,7 \\
\hline Fonte: (SILVA
\end{tabular}

Fonte: (SILVA, C. P. C., 2013) 
Figura 36 - Produção de peróxido de hidrogênio pelos neutrófilos $\mathrm{CH} 138+($ Low) do colostro e leite, estimulados com Escherichia coli: (A) - Proporção (\%); (B) - Intensidade (Média Geométrica) em vacas Holandesas no período de transição - São Paulo 2013

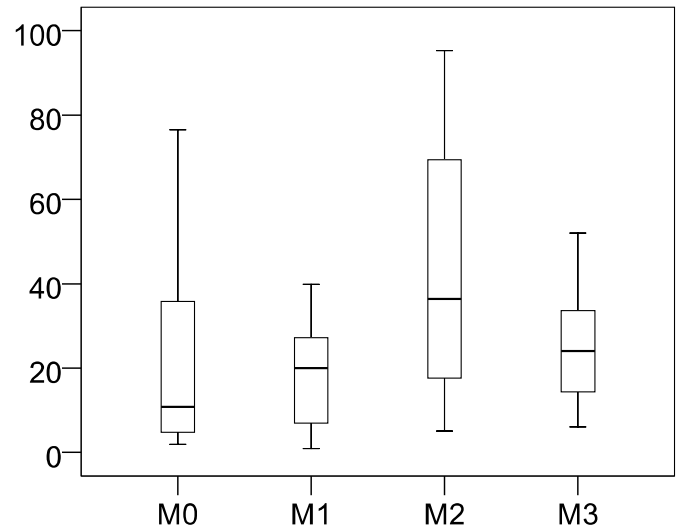

(A)

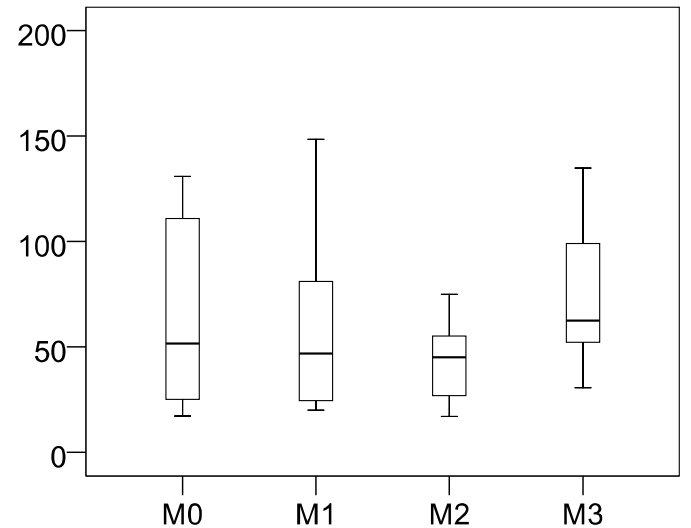

(B)

Fonte: (SILVA, C. P. C., 2013)

Figura 37 - Produção de peróxido de hidrogênio pelos neutrófilos $\mathrm{CH} 138+$ (High) do colostro e leite, estimulados com Escherichia coli: (A) - Proporção (\%); (B) - Intensidade (Média Geométrica) em vacas Holandesas no período de transição - São Paulo 2013

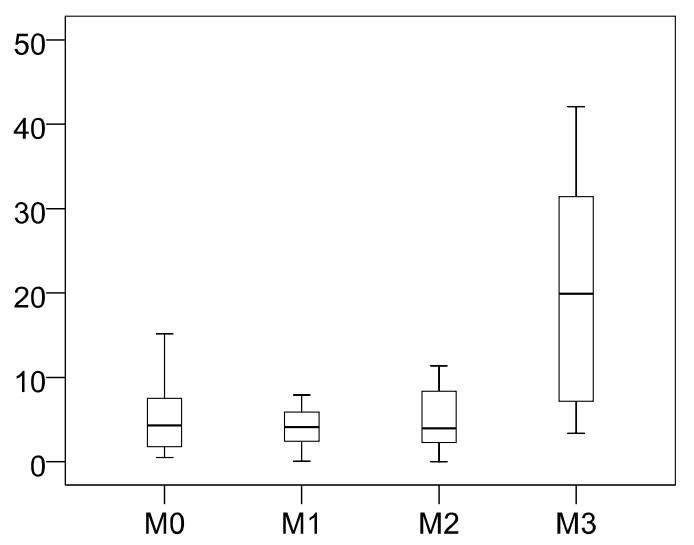

(A)

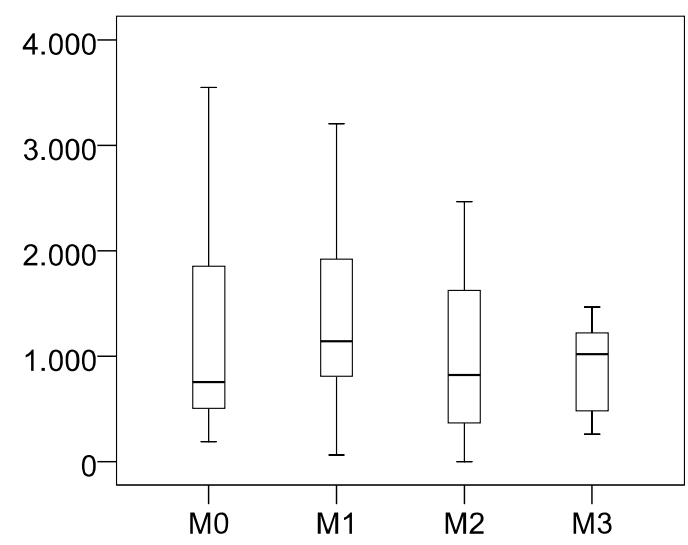

(B)

Fonte: (SILVA, C. P. C., 2013) 


\subsubsection{Mensuração de Citocina - Interferon Y}

Obteve-se absorbâncias abaixo da curva padrão para todas as amostras de soro lácteo e sanguíneo, sendo consideradas negativas. 


\section{DISCUSSÃO}

O período periparto em vacas leiteiras é caracterizado por adaptações fisiológicas, nutricionais e metabólicas associadas à diminuição da função dos neutrófilos sanguíneos e da glândula mamária, e aumento na incidência de doenças da produção. Elevadas taxas de infecção mamária no período pós-parto imediato e escassez de estudos avaliando a função dos fagócitos polimorfonucleares do colostro bovino motivaram o desenvolvimento desta pesquisa. Desta forma, esta pesquisa avaliou a resposta imune inata no sangue, colostro e leite de vacas Holandesas no período de transição.

\subsection{EXAME ESPECÍFICO DA GM}

As alterações obtidas no exame específico da GM, observadas especialmente nas semanas $\mathrm{M}-1, \mathrm{M} 0$ e $\mathrm{M} 1$, podem ter relação com o edema fisiológico da $\mathrm{GM}$, presente em $95 \%$ das vacas leiteiras nas proximidades do parto. Este fenômeno ocorre pela transferência do fluxo sanguíneo redirecionado do feto para a GM e produção de colostro (DENTINE; MC DANIEL, 1983; HIBBIT; CRAVEN; BATTEN, 2008), se inicia semanas antes do parto e cessa abruptamente na parição sob influências hormonais (BRANDON; WATSON; LASCELLES, 1971; McFADDEN; BESSER; BARRINGTON, 1997; BARRINGTON ET AL., 2001) Elevadas frequências de glândulas apresentando aumento de volume generalizado, diminuição da elasticidade da pele, aumento de temperatura local e coloração avermelhada próximo ao parto, são compatíveis com o edema fisiológico da GM. A princípio esperava-se encontrar glândulas com consistência pastosa classicamente encontrada nos edemas, no entanto, observou-se consistência firme do parênquima mamário na maioria das vacas recém-paridas, provavelmente pela retenção da secreção mamária acumulada no período de colostrogênese. 
A similaridade entre os achados do edema fisiológico da GM com aqueles oriundos de processos inflamatórios limita o diagnóstico da mastite nos momentos pré e pós-parto imediatos. Além disso, o edema fisiológico é um fator de risco para instalação dos patógenos bacterianos, devido à sua relação com o estresse versus imunidade, sensibilidade, aumento da tensão da pele e mamas pendulosas (MONTERO, 2013).

\subsection{EXAME BACTERIOLÓGICO DO LEITE}

A taxa de isolamento bacteriano observada nesta pesquisa foi maior no préparto e parto em relação às semanas M2 e M3. A taxa de infecção bacteriana encontrada na parição foi maior que as frequências de 12 e 19,3\% relatadas por Pinedo; Flaming; Risco (2012) e Gomes et al. (2011), respectivamente. As diferenças obtidas entre os estudos podem ter associação com o status sanitário do rebanho.

Compton et al. (2007) ao avaliar novilhas, encontrou $21,5 \%$ de quartos mamários positivos ao exame bacteriológico no segundo dia pós-parto, concordando com dados encontrados nesta pesquisa em período equivalente $(21,16 \%)$.

A maior ocorrência da infecção bacteriana nos quartos mamários nos momentos pré-parto e parto em relação ao M2 e M3 pode ter ocorrido devido ao acúmulo de secreção na glândula mamária e consequente aumento na pressão local, causando dilatação no canal do teto e favorecimento para a penetração das bactérias da microbiota da pele dos tetos ou patógenos ambientais. Além disso, a proximidade do aparelho mamário ao solo e ausência de manejo de ordenha no período são fatores de risco para mastite ambiental (OLIVER; DODD; NEAVE, 1956).

Bactérias do grupo de Staphylococcus coagulase-negativa foram os patógenos predominantemente isolados na secreção mamária das vacas no periparto, coincidindo com os dados de Dingwell et al. (2002); Rajala-Schultz; Hogan; Smith (2005) e Odensten et al. (2007) para amostras obtidas no pós-parto 
imediato. Estas bactérias são chamadas "flora oportunista da pele e tetos". No periparto, desequilíbrios imunológicos no ambiente mamário durante o período de transição podem favorecer a penetração destes microrganismos no ambiente mamário, porém a efetividade da resposta imune inata pode eliminá-los antes do desenvolvimento da doença e alterações perceptíveis na produção leiteira (SORDILLO, 2005).

A taxa de isolamento de coliformes e Streptococcus spp. foi baixa, descordando-se da importância dada para estes patógenos no período seco e colostrogênese por Todhunter; Smith; Hogan (1995) e Radostitis et al. (2002).

As limitações da aplicação do exame específico da GM no periparto não permitem afirmar que os patógenos isolados ocasionaram doença. Existe a possibilidade de infecção e eliminação dos patógenos com o início do manejo de ordenha no pós-parto imediato e aumento da eficiência da resposta imune inata.

\subsection{RESPOSTA IMUNE INATA NO SANGUE}

Foi possível identificar variações do número absoluto e proporções de PMN e neutrófilos $\mathrm{CH}_{138^{+}}$durante o período de transição, leucocitose por neutrofilia, decorrentes de alterações fisiológicas relacionadas especialmente ao trabalho de parto. Foi possível verificar que as alterações sanguíneas refletiram as condições orgânicas das vacas no período de transição, que não são restritas à glândula mamária.

As proporções de $\mathrm{PMN}$ e neutrófilos $\mathrm{CH} 138^{+}$do sangue foram constantes durante o período pré-parto, observando evidente neutrofilia no momento da parição. Saut e Birgel Junior (2006) avaliaram a proporção de neutrófilos em vacas Holandesas no momento do parto, detectando leucocitose por neutrofilia com desvio à esquerda regenerativo.

Os níveis de cortisol aumentam de $20 \mathrm{pg} / \mathrm{mL}$ no início da gestação, para picos entre 4000 e $6000 \mathrm{pg} / \mathrm{mL}$ nos momentos antes do parto (CHEW et al., 1977). O cortisol estimula a liberação pela medula óssea de neutrófilos segmentados e bastonetes do compartimento estoque para a circulação. Além disso, este hormônio 
influencia na diminuição das moléculas de adesão expressas na superfície dos neutrófilos, o que leva a diminuição da ligação dessas células com as células endoteliais, aumentando o número dos neutrófilos na circulação com redução no compartimento marginal (MADDUX; KEETON, 1987; BURTON et al., 1995; LA et al., 2001; WEBER; TOELBOELL; CHANG, 2004), portanto, o aumento, dos neutrófilos ocorre pela soma dos neutrófilos circulantes com os liberados do estoque da medula óssea (GUIDRY; PAAPE; PEARSON, 1976). Outra hipótese que justificaria a neutrofilia seria a estimulação das células-tronco para proliferação e diferenciação das células mielóides pelo aumento do fator estimulador de colônias de granulócitos (LEE; KEHRLI, 1998).

O pico de neutrófilos $\mathrm{CH}_{138^{+}}$sanguíneos também coincidiu com a maior taxa de infecção bacteriana da glândula mamária no momento da parição (M0). A resposta leucocitária em ruminantes é caracterizada por neutropenia, devido à rápida migração das células do sangue para o local da infecção. No entanto, após 35 do início do processo infeccioso, observa-se leucocitose por neutrofilia com desvio à esquerda pelo aumento da produção (WOOD; QUIROZ-ROCHA, 2010). Esse aumento no número de PMN e neutrófilos no sangue no M0 também pode ter relação com as elevadas taxas de infecção bacteriana observadas nesse momento.

No período entre o pós-parto imediato e a semana M1 observou-se diminuição da proporção de $\mathrm{PMN}$ e células $\mathrm{CH} 138^{+}$, provavelmente pela adaptação da vaca entre seu status fisiológico de gestação para lactação. Hoedemaker; Lund; Wagner (1992) avaliaram a proporção de leucócitos e neutrófilos no sangue de vacas, e afirmaram que no terceiro dia pós-parto, o valor de neutrófilos chegou aos níveis mais baixos em relação aos observados na pesquisa, e relacionaram essa diminuição com o fluxo dessas células para o útero e glândula mamária.

A partir da semana M2 observou-se aumento da proporção de PMN e neutrófilos $\mathrm{CH}_{138^{+}}$, provavelmente pela maior ocorrência de inflamações uterinas observadas nesta pesquisa.

A função dos neutrófilos sanguíneos $\mathrm{CH}_{138^{+}}$foi mais intensa no momento $\mathrm{M}$ 3 em relação aos demais momentos do período de transição, observando-se picos máximos da intensidade da fagocitose da bactéria Staphylococcus aureus; proporção de neutrófilos $\mathrm{CH}_{138^{+}}$low produzindo $\mathrm{H}_{2} \mathrm{O}_{2}$ estimuladas pelo Staphylococcus aureus; intensidade da produção de $\mathrm{H}_{2} \mathrm{O}_{2}$ pelas células $\mathrm{CH} 138^{+}$low 
e high com estímulo bacteriano (S.aureus); e proporção de $\mathrm{CH} 138^{+}$produzindo $\mathrm{H}_{2} \mathrm{O}_{2}$ estimulados com Escherichia coli. Interessante observar que a resposta mais intensa foi para S.aureus que Escherichia coli, talvez a redução do receptor Toll-like 4 nos neutrófilos sanguíneos de vaca leiteira no período de transição pode ser responsável por esse achado, pois esse receptor é responsável pela ligação entre fagócito e bactérias Gram-negativas na primeira etapa da fagocitose.

Este período (M-3) é o mais distante da parição e antecede as principais alterações hormonais e metabólicas do parto, desta forma, acredita-se que esse momento do período de transição é o que mais se aproxima das condições fisiológicas da vaca observadas na lactação. Mehrzad et al. (2002) também encontrou pico máximo da produção de EROs na terceira semana que antecedeu o parto em relação às demais semanas no período de transição.

O M-2 e M-1 apresentaram redução da função celular, porém observou-se aumento marcante na função dos neutrófilos $\mathrm{CH}_{138^{+}}$no parto (M0), observando-se picos máximos na proporção de células $\mathrm{CH} 138^{+}$low produzindo $\mathrm{H}_{2} \mathrm{O}_{2}$ estimulados com Escherichia coli; e intensidade de $\mathrm{H}_{2} \mathrm{O}_{2}$ produzido pelas populações $\mathrm{CH} 138^{+}$ low e high também estimulados com Escherichia coli. Além disso, observou-se aumento da fagocitose e produção de $\mathrm{H}_{2} \mathrm{O}_{2}$ com e sem estímulo no $\mathrm{M} 0$ em relação a M-2 e M-1 considerando-se a maioria dos parâmetros avaliados, diferindo dos dados obtidos por Kehrli; Nonnecke; Roth (1989), Mehrzad et al. (2001) e Mehrzad et al. (2002) que verificaram a menor atividade das enzimas mieloperoxidase e NADPHoxidase nas células sanguíneas no início do pós-parto. Provavelmente este aumento da função celular no parto observada nesta pesquisa foi decorrente da maior taxa de infecção mamária, pois Mehrzad; Duchateau; Burvenich (2004) demonstraram maior produção de radicais livres após inoculação experimental com Escherichia coli.

Observou-se tendência a diminuição da função dos neutrófilos sanguíneos no momento $\mathrm{M} 1$ em relação ao $\mathrm{M0}$, no entanto os parâmetros voltaram a aumentar no M2. Ressalta-se que no M2 foi observada maior taxa de infecções uterinas e menor taxa de infecção bacteriana mamária em relação aos demais períodos. Assim, acreditamos que a presença de endometrites e metrites nas vacas desta pesquisa pode ter contribuído para o aumento da função dessas células no M2. 


\subsection{RESPOSTA IMUNE INATA DA GLÂNDULA MAMÁRIA}

A resposta imune inata da glândula mamária foi avaliada pela CCS, viabilidade celular e atividade funcional de neutrófilos PMN.

O colostro apresentou maior CCS em relação aos valores obtidos nas semanas 1, 2 e 3 pós-parto. $O$ acúmulo de leucócitos durante o processo de colostrogênese e a descamação das células epiteliais de revestimento da glândula mamária pode ser responsável pela alta celularidade do colostro. O início do processo de ordenha promove a saída de bactérias, células e debris acumulados na secreção mamária, observando-se diminuição da celularidade do leite. A baixa celularidade do leite entre as semanas +1 e +3 pós-parto dificultou a obtenção de leucócitos viáveis, diminuindo o número de amostras lácteas consideradas aptas para inclusão nos ensaios da avaliação da função das células presentes na secreção mamária.

Os resultados obtidos para a CCS do colostro bovino são divergentes, pois o resultado obtido nesta pesquisa $\left(1,6 \times 10^{6}\right.$ células $\left./ \mathrm{mL}\right)$ foi superior aos valores de $0,6 \times 10^{6}$ e $0,88 \times 10^{6}$ cél $/ \mathrm{mL}$ obtidos por Mc Donald e Anderson (1981) e Gomes et al. (2011), respectivamente. Por outro lado, estes valores foram menores que os obtidos por Jensen \& Eberhart (1981) $\left(2,6 \times 10^{6}\right.$ cél $\left./ \mathrm{mL}\right)$. O estado de higidez mamária e taxa de infecção bacteriana podem ser responsáveis pelas diferenças observadas, pois Gomes et al. (2011) avaliaram apenas GM hígidas e Jensen \& Eberhart não excluíram amostras de colostro provenientes de quartos infectados.

A CCS no colostro de vacas infectadas $\left(1,7 \times 10^{6}\right.$ células $\left./ \mathrm{mL}\right)$ foi maior que as obtidas na secreção mamária de vacas não infectadas $\left(1,3 \times 10^{6}\right.$ células $\left./ \mathrm{mL}\right)$, no entanto, não foram observadas diferenças estatísticas entre as contagens. Assim, pode-se afirmar que este parâmetro não deve ser utilizado como indicador de mastite no pós-parto imediato, conforme descrito por Reis et al. (2013). Este fenômeno difere dos obtidos das amostras de leite de vacas em lactação plena, onde a CCS é uma importante ferramenta para diagnóstico da mastite bovina (MAUNSELL et al., 1998; YU et al., 2011; PILLA et al., 2012).

A diminuição da CCS no primeiro mês pós-parto também foi relatada por Mehrzad et al. (2001). A baixa celularidade do leite entre as semanas +1 a +3 pós- 
parto é compatível com a baixa taxa de infecção mamária observada no período (7 a $21 \%$ ) e ausência de mastite clínica.

A viabilidade dos leucócitos obtidos do colostro e leite de vacas no periparto apresentou aumento do M0 ao M3, tornando-se semelhantes nos últimos dois momentos (M2/M3). Mehrzad et al. (2001) também observaram aumento na taxa de viabilidade dos $\mathrm{PMN}$ entre $03^{\circ}$ ao $11^{\circ}(27 \%)$ em relação às demais semanas (42 e $49 \%)$.

A viabilidade celular do colostro (32\%) foi semelhante ao valor (30\%) obtido por Godden et al. (2012). Apesar do aumento da viabilidade dos leucócitos no leite (45 a 57\%), o número de células somáticas diminui drasticamente, resultando em baixa concentração de leucócitos viáveis $\left(0,45\right.$ a $1,1 \times 10^{6}$ células $\left./ \mathrm{mL}\right)$ e inadequação de amostras (47 a 78\%) para realização dos ensaios para avaliação da função dos neutrófilos do leite.

Os resultados da viabilidade celular da secreção mamária obtidos nesta pesquisa estão compatíveis com a amplitude de variação (10,5 a 85\%) observada por Piepers; De Vliecher; Demeyer (2009). No $21^{\circ}$ pós-parto (M3) obtivemos viabilidade nos leucócitos do leite (52,5\%) inferior ao valor de 63\% observado por Mehrzad et al. (2004), no mesmo período, em vacas livres de infecção mamária.

A avaliação da proporção de neutrófilos $\mathrm{CH}_{138^{+}}(10 \%)$ pela técnica de citometria de fluxo apontou para o insucesso da separação dos neutófilos dentre os demais componentes celulares por gradiente de densidade usando Histopaque 1.119 e 1.083. Acredita-se que o Histopaque 1.119 foi fundamental para separação dos debris celulares e gordura, facilitando a obtenção dos leucócitos. No entanto, a alta proporção de mononucleares $(\mathrm{MN})$ sedimentou durante o processo de separação com o Histopaque 1.083, resultando na impureza da suspensão de PMN. Este fato já havia sido relatado por Gomes et al. (2010). A proporção de neutrófilos observada no colostro por citometria de fluxo foi semelhante a obtida por Gomes et al. (2011) pela técnica de citocentrifugação (13\%).

A separação das células MN e PMN do leite foi inviável considerando a baixa celularidade observada, optando-se pela marcação das células totais da secreção mamária com o anticorpo monoclonal anti-bovine $\mathrm{CH}_{138^{+}}$. Apesar do aumento na proporção de neutrófilos $\mathrm{CH}_{138^{+}}$do colostro (10\%) em relação às semanas subseqüentes $(59,5 \%)$, não foi possível comparar os valores considerando-se os 
diferentes processos de separação adotados para o colostro e leite. Não foram observadas diferenças entre as proporções de neutrófilos entre as semanas M1 a M3.

A função dos neutrófilos $\mathrm{CH}_{138^{+}}$presentes no colostro e leite das vacas Holandesas foi avaliada nas primeiras semanas pós-parto (M0 a M3). A análise conjunta dos parâmetros avaliados em relação à resposta imune nos permite afirmar que a função dos neutrófilos $\mathrm{CH}_{138^{+}}$da secreção mamária apresentou-se diminuída no $\mathrm{M} 0$, em relação aos demais momentos deste estudo, especialmente M2 e M3. Interessante observar que a data da parição foi o momento de maior taxa de infecção mamária $(33,34 \%)$ e maior celularidade.

Na primeira semana pós-parto (M1) foram observados picos máximos em três dos 14 parâmetros avaliados para a função dos neutrófilos, porém em relação aos demais parâmetros observaram-se menores valores que aqueles obtidos em M2 e M3. Mehrzad et al. (2001) avaliaram a função dos PMN da secreção mamária em três períodos: 3-11 dias pós-parto, 12-20 dias pós-parto e 21-30 dias pós-parto, e verificaram diminuição da produção de radicais livres e viabilidade celular no primeiro período de estudo. Além disso, Mehrzad et al. (2002) compararam a função dos PMN de vacas multíparas versus primíparas, verificaram que entre o $2^{\circ}$ e $3^{\circ}$ dias pós-parto, a produção de EROs teve o seu menor valor em ambos os grupos.

No momento M2 observou-se aumento dos índices de fagocitose, porém a produção de EROs foi exacerbada em M3. Entre os momentos M2 e M3, observouse aumento da taxa de infecção mamária de 7 para 17\%, acreditando-se que a resposta imune inata pode ter relação com a pressão de microrganismos. Mehrzad et al. (2004) observaram aumento da produção de EROs pelos PMN do leite após inoculação experimental com Escherichia coli.

Os maiores índices de fagocitose e produção de ERO no M2 e M3 pode indicar adaptação orgânica da vaca no pós-parto e amplificação da resposta imune da glândula mamária frente aos patógenos. É importante destacar que nenhuma das vacas examinadas apresentou mastite clínica no M2 e M3.

Após verificar a dinâmica da função dos neutrófilos $\mathrm{CH}_{138^{+}}$conforme a sequência das semanas, e relembrar os dados acima citados para CCS e viabilidade das células da secreção mamária, verificou-se que ocorreu aumento na função dos $\mathrm{CH} 138^{+}$, diminuição da CCS, e aumento na viabilidade dos leucócitos, na secreção 
mamária. Essas observações estão de acordo com os achados de Rivas et al. (2006) ao avaliar a atividade fagocítica dos neutrófilos e macrófagos do leite de vacas livres de infecção mamária, com alta e baixa celularidade, concluíram que a alta celularidade estava associada com baixa viabilidade, e com Mehrzad et al. (2004) que encontraram correlação positiva entre viabilidade e produção de EROs pelos PMN do leite após infectar experimentalmente quartos de vacas leiteiras com Escherichia coli.

A partir dos dados obtidos para a função dos neutrófilos $\mathrm{CH} 138^{+}$do sangue e secreção mamária, foi possível observar que as funções dos neutrófilos da secreção mamária se apresentaram diminuídas em relação aos mesmos parâmetros no sangue durante o período de estudo. As diferenças mais marcantes foram em relação às intensidades (média geométrica) de fagocitose e produção de $\mathrm{H}_{2} \mathrm{O}_{2}$. Além disso, a proporção (\%) de células high que produziram $\mathrm{H}_{2} \mathrm{O}_{2}$ foi evidentemente maior nos neutrófilos do sangue versus secreção mamária, acreditando-se que essa baixa proporção de células com capacidade alta de produzir EROS intracelular pode comprometer a resposta e proteção da GM neste período. Mehrzad et al. (2009) ao avaliar a atividade funcional dos neutrófilos contra Staphylococcus aureus do sangue versus leite de vacas multíparas nos primeiros 30 dias de lactação, verificaram que a fagocitose foi de $30 \%$ contra $20 \%$, para as células do sangue e leite respectivamente, e proporção (\%) de bactérias mortas de $23,2 \%$ contra $10,2 \%$, respectivamente. 


\section{CONCLUSÕES}

Com base nos resultados obtidos, pode-se concluir que:

a) A parição representou o momento com maior taxa de infecção mamária, no entanto, as alterações mamárias decorrentes do processo de colostrogênese limitaram o uso de exame específico do aparelho mamário para detecção da mastite clínica;

b) A função dos neutrófilos sanguíneos nos momentos M-2 e M-1 apresentouse diminuída, este fenômeno pode ter contribuído para maiores taxas de infecção mamária e exacerbação da função dos neutrófilos sanguíneos no momento da parição;

c) A resposta nos neutrófilos sanguíneos não foi exclusiva da GM e apresentaram-se intensificadas nos momentos com alta freqüência de inflamações uterinas no pós-parto;

d) A GM apresenta-se altamente susceptível às infecções bacterianas no pósparto imediato, decorrente da baixa viabilidade celular, reduzida proporção e atividade funcional dos neutrófilos $\mathrm{CH} 138^{+}$residentes. A adaptação ao pós-parto e aumento da atividade funcional dos neutrófilos da secreção mamária foi observada nas semanas subsequentes ao parto, resultando em diminuição da taxa de infecção bacteriana. 


\section{REFERÊNCIAS}

ABBAS, A. K.; LICHTMAN, A. H. Imunidade inata: a defesa inicial contra as infecções. In: -----. Imunologia Básica. 2 ed. Rio de Janeiro: Elsevier, 2007.

ALLUWAIMI, A. M. The cytokines of bovine mammary gland: prospects for diagnosis and therapy. Research in Veterinary Science, v. 77, n. 3, p. 211-222, 2004.

ALLUWAIMI, A. M.; CULLOR, J. S. Cytokines gene expression patterns of bovine milk during middle and late stages of lactating period. Journal of Veterinary Medicine. B, Infectious Diseases and Veterinay Public Health, v. 49, p. 105-110, 2002.

BABIOR, B. M. The Respiratory burst of phagocytes. Journal of Clinical Investigation, v. 73, n. 3, p. 599-601, 1984.

BARBOSA LIMA, M. G. Perfil das citocinas no prognóstico da mamite bovina após antibioticoterapia, 2014. 85 f. Dissertação (Mestrado em Medicina Veterinária) - Faculdade de Medicina Veterinária e Zootecnia, Universidade de São Paulo, São Paulo, 2014.

BARRINGTON, G. M.; MCFADDEN, T. B.; HUYLER, M. T.; BESSER, T. E. Regulation of colostrogenesis in cattle. Livestock Production Science, v. 70, n. 1-2, p. 95-104, 2001.

BRADLEY, A. J.; GREEN, M. J. A study of the incidence and significance of intramammary enterobacterial infections acquired during the dry period. Journal of Dairy Science, v. 83, n. 9, p. 1957-65, 2000.

BRANDON, M. R.; WATSON, D. L.; LASCELLES, A. K. The mechanism of transfer of immunoglobin into mammary secretion of cows. The Australian Journal of Experimental Biology and Medical Science, v. 49, p. 613-623, 1971.

BURTON, J. L.; KEHRLI JR.; M. E.; KAPIL S.; HORST R. L. Regulation of L-selectin and CD18 on bovine neutrophils by glucocorticoids: effects of cortisol and dexamethasone. Journal of Leukocyte Biology, v. 57, p. 317-325, 1995

BUTLER, J.E. Bovine immunoglobulins: an augmented review. Veterinary Immunology and Immunopathology, v. 4, p. 43, 1983.

CAI, T. Q.; WESTON, P. G.; LUND, L. A.; BRODIE, B.; MCKENNA, D. J.; WAGNER, W. C. Association between neutrophil functions and periparturient disorders in cows. American Journal of Veterinary Research, v. 55, p. 934, 1994. 
CAPUCO, A. V.; AKERS, R. M.; SMITH, J. J. Mammary growth in Holstein cows during the dry period: Quantification of nucleic acids and histology. Journal of Dairy Science, v. 80, p. 477-487, 1997.

CAPUCO, A. V.; WOOD, D. L.; BALDWIN, R.; MCLEOD, K.; PAAPE, M. J. Mammary cell number, proliferation, and apoptosis during a bovine lactation: relation to milk production and effect of bST. Journal of Dairy Science, v. 84, n. 10, p. 2177-2187, 2001.

CASWELL, J. L.; MIDDLETON, D. M.; GORDON, J. R. The importance of interleukin8 as a neutrophil chemoattractant in the lungs of cattle with pneumonic pasteurellosis. Canadian Journal Veterinary Research, v. 65, p. 229-232, 2001.

CHEW, B. P.; KELLER, H. F.; ERB, R. E.; MALVEN, P. V. Periparturient Concentrations of Prolactin , Progesterone and the Estrogens in Blood Plasma of Cows Retaining and not Retaining Fetal. Journal of Animal Science, v. 44, p. 1055-1060, 1977.

COMPTON, C. W. R.; HEUER, C.; PARKER, K.; MCDOUGALL, S. Epidemiology of mastitis in pasture-grazed peripartum dairy heifers and its effects on productivity. Journal of Dairy Science, v. 90, n. 9, p. 4157-70, 2007.

CONCHA, C.; HOLMBERG, O.; ASTROM, G. Cells found in non-infected and Staphylococcus-infected bovine mammary quarters and their ability to phagocytose fluorescent microspheres. Journal of Veterinary Medicine, v. 33, n. 1-10, p. 371378, 1986.

CRAVEN, N.; Chemotactic factors for bovine neutrophils in relationto to mastitis. Comparative Immunology, Microbiology \& Infectious Diseases, v. 9, n. 1, p. 2936, 1986.

DALEY, M. J.; COYLE, P. A.; WILLIAMS, T. J.; FURDA, G.; DOUGHERTY, R.; HAYES P. W. Staphylococcus aureus mastitis: pathogenesis and treatment with bovine interleukin-1 beta and interleukin-2. Journal of Dairy Science, v. 74, p. 4413-4424, 1991.

DENTINE, M. R.; McDANIEL, B. T. Variation of edema scores from herd-year, age, calving month, and sire. Journal of Dairy Science, v.66, p. 2391-2399, 1983.

DINGWELL, R. T.; DUFFIELD, T. F.; LESLIE, K. E.; KEEFE, G. P.; DESCOTEAUX, L.; KELTON, F.; LISSEMORE, K. D.; SCHUKKEN, Y. H.; DICK, P.; BAGG, R. The efficacy of intramammary tilmicosin at drying-off, and other risk factors for the prevention of new intramammary infections during the dry period. Journal of Dairy Science, v. 85, p. 3250-3259, 2002.

EBERHART, R. J. Management of Dry Cows to Reduce Mastitis. Journal of Dairy Science, v. 69, n. 6, p. 1721-1732, 1986. 
GENNARO, R.; DEWALD, B.; HORISBERGER, U.; GUBLER, H. U.; BAGGIOLINI, $M$. A novel type of cytoplasmic granule in bovine neutrophils. The Journal of Cell Biology, v. 96, p. 1651-61, 1983.

GODDEN, S. M.; SMOLENSKI, D. J.; DONAHUE, M.; OAKES, J. M.; BEY, R.; WELLS, S.; SREEVATSAN, S.; STABEL, FETROW, J. Heat-treated colostrum and reduced morbidity in preweaned dairy calves: Results of a randomized trial and examination of mechanisms of effectiveness. Journal Dairy Science, v. 95, p. 40294040, 2012.

GOFF, J. P.; HORST, R. L. Physiological changes at parturition and their relationship to metabolic disorders. Journal of Dairy Science, v. 80, p. 1260-1268, 1997.

GOMES, V. Componentes imunológicos do colostro bovino: células, teores de imunoglobulinas e atividade bactericida dos fagócitos para a Escherichia coli enterotoxigênica (ECET), 2008, 106 f. Tese (Doutorado em Medicina Veterinária) Faculdade de Medicina Veterinária e Zootecnia, Universidade de São Paulo, São Paulo, 2008.

GOMES, V.; MADUREIRA, K. M.; DELLA LIBERA, A. M. M. P.; BLAGITZ, M. G.; ALVES, M.; BAPTISTELLA, F.; BENESI, F.J. Dinâmica da celularidade do colostro de vacas da raça Holandesa no pós-parto imediato. Arquivo Brasileiro de Medicina Veterinária e Zootecnia, v. 63, n. 5, p. 1047-1053, 2011.

GOMES, V.; MADUREIRA, K. M.; DELLA LIBERA, A. M. M. P.; BLAGITZ, M. G.; BENESI, F.J. Viability of mononuclear and polymorfonuclear phagocytes of bovine colostrums immediately after delivery. Cell separation by density gradient. In: Proceedings World Buiatrics Congress. 26., Santiago, 2010, p. 136.

GRAY, G. D.; KNIGHT, K. A.; NELSON, R. D.; HERRON, M. J. Chemotactic requirements of bovine leukocytes. American Journal of Veterinary Research, v. 43, p. 757-759, 1982.

GREWAL, A. S.; ROUSE, B. T.; BABIUK, L. A. Characterization of surface receptors on bovine leukocytes. International Archives of Allergy and Applied Immunology, v. 56, p. 289-300, 1978.

GRINBERG, N.; ELAZAR, S.; ROSENSHINE, I.; SHPIGEL, N. Y. Betahydroxybutyrate abrogates formation of bovine neutrophil extracellular traps and bactericidal activity against mammary pathogenic Escherichia coli. Infection and Immunity, v. 76, n. 6, p. 2802-2807, 2008.

GUIDRY, A. J.; PAAPE, M. J.; PEARSON, R. E. Effects of parturition and lactation on blood and milk cell concentrations, corticosteroids, and neutrophil phagocytosis in the cow. American Journal of Veterinary Research, v. 37, n 10, p. 1195-1200, 1976. 
HAMMON, D. S.; EVJEN, I. M.; DHIMAN, T. R.; GOFF, J. P.; WALTERS, J. L. Neutrophil function and energy status in Holstein cows with uterine health disorders. Veterinary Immunology and Immunopathology, v. 113, p. 21-29, 2006.

HASUI, M.; HIRABAYASHI, Y.; KOBAYASHI, Y. Simultaneous measurement by flow cytometry of phagocytosis and hydrogen peroxide production of neutrophils in whole blood. Journal of Immunological Methods, v. 117, n. 1, p. 53-8, 1989.

HEIKKILÄ, A. M.; NOUSIAINEN, J. I.; PYÖRÄLÄ, S. Costs of clinical mastitis with special reference to premature culling. Journal of Dairy Science, v. 95, p. 139-150, 2012.

HIBBITT, K. G.; CRAVEN, N.; BATTEN, E. H.. In: ANDREWS, A. H. R.; BLOWEY, W.; BOYD, H.; EDDY, R. G. Medicina bovina: doenças e criação de bovinos. ed. São Paulo: Roca, 2008.

HIRABAYASHI, Y.; TANIUCHI, S.; KOBAYASHI, Y. A quantitative assay of oxidative metabolism by neutrophils in whole blood using flow cytometry. Journal of Immunological Methods, v. 82, n. 2, p. 253-9, 1985.

HOEDEMAKER, M.; LUND, L. A.; WAGNER, W. C. Influence of arachidonic acid metabolites and steroids on function of bovine polymorphonuclear neutrophils. American Journal of Veterinary Research, v. 53, n. 9, p.1534-1539, 1992.

HOGAN, J.; SMITH, K. L. Managing Environmental Mastitis. Veterinary Clinics of North America: food animal. v. 28, p. 217-224, 2012.

HORNEF, M. W.; WICK, M. J.; RHEN, M.; NORMARK, S. Bacterial strategies for overcoming host innate and adaptative immune responses. Nat. Immunol., v. 3, p. 1033-1040, 2002.

IBM Corp. Released 2011. IBM SPSS Statistics for Windows. Version 20.0. Armonk, NY: IBM Corp, 2011.

JENSEN, D. L.; EBERHART, R. J. Total e differential cell count in secretions of the nonlactating bovine mammary gland. American Journal of Veterinary Research, v. 42 , p. $743-747,1981$.

KAMPEN, A. H.; TOLLERSRUD, T.; LUND, A. Flow cytometric measurement of neutrophil respiratory burst in whole bovine blood using live Staphylococcus aureus. Journal of Immunological Methods, v. 289, n. 1-2, p. 47-55, 2004.

KEHRLI JR., M. E.; NONNECKE, B. J.; ROTH, J. A. Alterations in bovine neutrophil function during the periparturient period, American Journal of Veterinary

Research, v. 50, p. 207-214, 1989. 
KEMLER, R. H.; MOSSMANN, H.; STROHMAIER, B.; KICKHOFEN, B.; HAMMER, D.K. In vitro studies on the selective binding of IgG from different species to tissue sections of the bovine mammary gland. European Journal of Immunology v. 5, p. 603, 1975.

KIMURA, K.; GOFF, J. P.; KEHRLI, JR. M. E.; REINHARDT, T.A. Decreased neutrophil function as a cause of retained placenta in dairy cattle. Journal of Dairy Science, v. 85, p. 544-550, 2002.

KRIEG, N. R., HOLT, J.C. Bergey's manual of systematic bacteriology. 9. ed. Baltimore: Willians \& Wilkings, 1994. p. 1599.

LA, M.; TAILOR, A.; D’AMICO, M.; FLOWER, R. J.; PERRETTI, M. Analysis of the protection afforded by annexin 1 in ischaemia-reperfusion injury: focus on neutrophil recruitment. European Journal of Pharmacology, v. 429, p. 263-278, 2001.

LARSON, B. L. Biosynthesis and cellular secretion of milk. In: LARSON, B. L. Lactation. Ames, IA: The lowa State University Press, 1985. p. 129.

LARSON, B.L. Immunoglobulins of the mammary secretions. In: FOX, P.F. Advanced dairy chemistry 1: proteins. London, New York: Elsevier, 1992. p. 231.

LEE, C.; WOODING, F. B.; KEMP, P. Identification, properties, and differential counts of cell populations using microscopy of dry cows secretions, colostrum and milk from normal cows. Journal of Dairy Research, v. 47, p. $39-50,1980$.

LEE, E. K.; KEHRLI JR., M. E. Expression of adhesion molecules on neutrophils of periparturient cows and neonatal calves. American Journal of Veterinary Research, v. 59, n. 1, p. 37-43, 1998.

LEE, J.; ZHAO, X. Recombinant human interleukin-8, but not human interleukin1 beta, induces bovine neutrophil migration in an in vitro co-culture system. Cell Biology International, v. 24, n. 12, p. 889-895, 2000.

LENETTE, E. M.; BALOWS, A.; HANSLER JR., W. J. Manual of clinical microbiology. 4. ed. Washington: American Society of Microbiology, 1985. p. 254.

LIPPOLIS, J. D.; REINHARDT, T. A.; GOFF, J. P.; HORST, R. L. Neutrophil extracellular trap formation by bovine neutrophils is not inhibited by milk. Veterinary Immunology and Immunopathology, v. 113, n. 1-2, p. 248-255, 2006.

MADDUX, J. M.; KEETON, K. S. Effects of dexamethasone, levamisole, and dexamethasone-levamisole combination on neutrophil function in female goats. American Journal of Veterinary Research, v. 48, n. 7, p. 1114-1119, 1987.

MADUREIRA, K. M. Citocinas IL-1beta, IL-6, TNF-alpha e INF-gama no sangue e colostro de fêmeas bovinas da raça Holandesa. Importância na imunidade 
passiva, 2012. 106 f. Tese (Doutorado em Medicina Veterinária) - Faculdade de Medicina Veterinária e Zootecnia, Universidade de São Paulo, São Paulo, 2012.

MAUNSELL, F. P.; MORIN, D. E.; CONSTABLE, P. D.; HURLEY, W. L.; McCOY, G. C.; KAKOMA, I.; ISAACSON, R. E. Effects of mastitis on the volume and composition of colostrum produced by holstein cows. Journal of Dairy Science, v. 81, n. 5, 1998.

McDONALD, J. S.; ANDERSON, A. J. Total and diferential somatic cell counts in secretions from no ninfected bovine mammary glands: the peripartum period.

American Journal of Veterinary Research, v. 45, p. 1366-1368, 1981.

McFADDEN, T. B.; BESSER, T. E.; BARRINGTON, G. M. Regulation of immunoglobulin transfer into mammary secretions of rumin ants. In: WELCH, R.A.S., BURNS, D. J. W.; DAVIS, S. R.; PROSSER, C. G. Milk composition, production and biotechnology. Wallingford, UK: CAB International, 1997, Capítulo 9, p. 133.

MEGANCK, V.; GODDEERIS, B. M.; STUYVEN, E.; PIEPERS, S.; COX, E.; OPSOMER, G. Development of a method for isolating bovine colostrum mononuclear leukocytes for phenotyping and functional studies, The Veterinary Journal, v. 200, n. 2, p. 294-298, 2014.

MEHRZAD, J.; DOSOGNE, H.; MEYER, E.; HEYNEMAN, R.; BURVENICH, C. Respiratory burst activity of blood and milk neutrophils in dairy cows during different stages of lactation. The Journal of Dairy Research, v. 68, n. 3, p. 399-415, 2001.

MEHRZAD, J.; DUCHATEAU, L.; BURVENICH, C. Phagocytic and bactericidal activity of blood and milk-resident neutrophils against Staphylococcus aureus in primiparous and multiparous cows during early lactation. Veterinary Microbiology, v. 134, n. 1-2, p. 106-112, 2009.

MEHRZAD, J.; DUCHATEAU, L.; BURVENICH, C. Viability of milk neutrophils and severity of bovine coliform mastitis. Journal of Dairy Science, v. 87, n. 12, p. 41504162, 2004.

MEHRZAD, J.; DUCHATEAU, L.; PYORALA, S.; BURVENICH, C. Blood and milk neutrophil chemiluminescence and viability in primiparous and pluriparous dairy cows during late pregnancy, around parturition and early lactation. Journal of Dairy Science, v. 85, n. 12, p. 3268-3276, 2002.

MILLER R. H.; PAAPE, M. J.; FULTON. L. A. Variation in milk somatic cells of heifers at first calving. Journal Dairy Science, v. 74, p. 3782-3790, 1991.

MONTERO, A. S. Edema de ubre en ganado bovino. Nutrición Animal Tropical, v. 7, n 1, p. 25-39, 2013. 
MOREIRA DA SILVA, F.; BURVENICH, C.; MASSART-LEEN, A. M.; BROSSE, L. Assessment of blood neutrophil burst activity in dairy cows during the period of parturition. Journal of Animal Science, v. 67, p. 421-426, 1998.

MURPHY, K.; TRAVERS, P.; WALPORT, M. Imunidade inata. In:-----Imunobiologia de Janeway. 7. ed. Porto Alegre: Artmed, 2010.

MURRAY, P. R.; BARON, E. J.; PFALLER, M. A.; TENOVER, F. C.; YOLKEN, R. H. Manual of clinical microbiology. 7. ed. Washington: American Society for Microbiology, p. 365, 1999.

NATIONAL MASTITIS COUNCIL. Laboratory Handbook on Bovine Mastitis. Madison WI, USA: NMC, 1999.

NATIONAL RESEARCH COUNCIL. Nutrient requirements of dairy cattle. 7th rev. ed. Washington, D.C: National Academy Press. 2001. p. 381.

NEWMAN, K. A.; RAJALA-SCHULTZ, P. J.; LAKRITZ, J.; DEGRAVES, F. J. Lactoferrin concentrations in bovine milk prior to dry-off. Journal of Dairy Research, v. 76, p. 426-432, 2009.

ODENSTEN, M. O.; BERGLUND, B.; PERSSON WALLER, K.; HOLTENIUS, K. Metabolism and udder health at dry-off in cows of different breeds and production levels. Journal of Dairy Science, v. 90, p. 1417-1428, 2007.

OLIVER, J.; DODD, F. H.; NEAVE, F. K. Udder infections in the dry period. IV. The relationship between the new infection rate in the early dry period and the daily milk yield at drying-off when lactation was ended by either intermittent or abrupt cassation of milking. Journal Dairy Research, v. 23, p. 204, 1956.

ONTSOUKA, C. E.; BRUCKMAIER, R. M.; BLUM, J. W. Fractionized milk composition during removal of colostrum and mature milk. Journal of Dairy Science, v. 86, n. 6, p. 2005-2011, 2003.

OVIEDO-BOYSO, J.; VALDEZ-ALARCÓN, J. J.; CAJERO-JUÁREZ, M.; OchoaZarzosa, A.; López-Meza, J. E.; Bravo-Patiño, A.; Baizabal-Aguirre, V. M. Innate immune response of bovine mammary gland to pathogenic bacteria responsible for mastitis. The Journal of Infection, v. 54, n. 4, p. 399-409, 2007.

PAAPE, M. J.; BANNERMAN, D. D.; ZHAO, X.; LEE, J.-W. The bovine neutrophil: structure and function in blood and milk. Veterinary Research, v. 34, p. 597-627, 2003.

PAAPE, M. J.; GUIDRY, A. J. Effect of fat and casein on intracellular killing of Staphylococcus aureus by milk leukocytes. Proceedings of the Society for Experimental Biology and Medicine, v. 155, p. 588-593, 1977. 
PAAPE, M.; MEHRZAD, J.; ZHAO, X.; DETILLEUX, J.; BURVENICH, C. Defense of the bovine mammary gland by polymorphonuclear neutrophil leukocytes. Journal of Mammary Gland Biology and Neoplasia, v. 7, n. 2, p. 109-121, 2002.

PIEPERS, S.; DE VLIEGHER, S.; DEMEYERE, K. Techinical note: Flow cytometric identification of bovine milk neutrophils and simultaneous quantification of their viability. Journal of Dairy Science, v. 92, n. 2, p. 626-631, 2009.

PILLA, R.; SCHWARTZ, D.; KONIG, S.; PICCININI, R. Microscopic differential cell counting to identify inflammatory reactions in dairy cow quarter milk samples.

Journal of Dairy Science, v. 95, p. 4410-4420, 2012.

PINEDO, P. J.; FLEMING, C.; RISCO, C. A. Events occurring during the previous lactation, the dry period, and peripartum as risk factors for early lactation mastitis in cows receiving 2 different intramammary dry cow therapies. Journal Dairy Sciece, v. 95, p. 7015-7026, 2012.

RADOSTITIS, O. M.; GAY, C. C.; BLOOD, D. C.; HINCHCLIFF, K. W. MASTITE. In: Clínica veterinária. um tratado de doenças dos bovinos, ovinos, suínos, caprnos, e equinos. $9^{\text {th }}$ ed. Rio de Janeiro, Guanabara, 2002.

RAINARD, P. R.; RIOLLET, C. R. Review article Innate immunity of the bovine mammary gland. Veterinary Research, v. 37, p. 369-400, 2006.

RAJALA-SCHULTZ, P. J.; GROHN, Y. T.; McCULLOCH, C. E.; GUARD, C. L. Effects of clinical mastitis on milk yield in dairy cows. Journal of Dairy Science. v. 82, p. 1213-1220, 1999.

RAJALA-SCHULTZ, P. J.;HOGAN, J.S.;SMITH, K. L. Association between milk yield at dry-off and probability of intramammary infections at calving. Journal of Dairy Science, v. 88, p. 577-579, 2005.

RANDALL, W. E.; HEMKEN, R. W.; BULL, L.; DOUGLAS, L. W. Effect of dietary sodium and potassium on udder edema in holstein heifers. Journal of Dairy Science, v. 57, n. 4, p. 472-475, 1974.

REIS, J. F.;LEITE, R. F.; BENITES, N. R.; GOMES, V. Contagem de células somáticas (CCS) do colostro como indicador inflamatório da mastite bovina. In: SIMPÓSIO INTERNACIONAL DE INICIAÇÃO CIENTÍFICA DA UNIVERSIDADE DE SÃO PAULO, 21., Piracicaba. 2013. Disponível em:

<https://uspdigital.usp.br/siicusp/siicCDOnlineListaEdicao.jsp>. Acesso em: 05 fev. 2014.

RINALDI, M.; MORONI, P.; PAAPE, M. J.; BANNERMAN, D. D. Differential alterations in the ability of bovine neutrophils to generate extracellular and intracelular reactive oxygen species during the periparturient period. Veterinary Journal, v. 178, p. 208-213, 2008. 
RIVAS, A. L.; TADEVOSYAN, R.; GOREWIT, R. C.; ANDERSON, K. L.; LYMAN, R.; GONZÁLEZ, R. N. Relationships between the phagocytic ability of milk macrophages and polymorphonuclear cells and somatic cell counts in uninfected cows. Canadian Journal of Veterinary Research, v. 70, n. 1, p. 68-74, 2006.

ROSENBERGER, G. Exame clínico dos bovinos. Rio de Janeiro: Guanabara Koogan, 1993.

RUEGG, P. L. Managing mastitis and producing quality milk. In: RISCO, C. A.; RETAMAL, P. M. Dairy production medicine. Malden: Wiley-Blackwell, 2011.

SAUT, J. P. E.; BIRGEL JUNIOR, E. H. Variação dos constituintes do eritrograma em vacas Holandesas no pós-parto. Bioscience Journal, v. 28, n. 5, p. 805-809, 2006.

SCHALM, O. W.; LASMANIS, J.; CARROLL, E. J. Effects of pré-existing leukocytosis on experimental coliform (Aerobacter aerogenes) mastitis in cattle. American Journal of Veterinary Research, v. 25, p. 83-89, 1964.

SHELDON, I. M.; LEWIS, G. S.; LEBLANC, S.; GILBERT, R. O. Defining postpartum uterine disease in cattle. Theriogenology, v. 65, p. 1516-1530, 2006.

SHUSTER, D. E.; JUNIOR, M. E. K.; RAINARD, P.; PAAPE, M. Complement fragment $\mathrm{C} 5 \mathrm{a}$ and inflammatory cytokines in neutrophil recruitment during intramammary infection with Escherichia coli. Infection and Immunity, v. 65, n. 8, p. 3286-3292, 1997.

SLÁDEK, Z.; RYSÁNEK, D. Neutrophil apoptosis during the resolution of bovine mammary gland injury. Research in Veterinary Science, v. 70, p. 41-46, 2001.

SMITH, K.L., SCHANBACHER, F.L. Hormone induced lactation in the bovine. Lactational performance following injection of $17 \mathrm{~b}$-oestradiol and progesterone. Journal Dairy Science, v. 56, p. 738, 1973.

SMITH, K. L.; TODHUNTER, D. A.; SCHOENBERGER, P.S. Environmental pathogens and intramammary infection during the dry period. Journal Dairy Science, v. 68, p. 402-417,1985.

SMITS, E.; BURVENICH, C.; HEYNEMAN, R. Simultaneous flow cytometric measurement of phagocytotic and oxidative burst activity of polymorphonuclear leukocytes in whole bovine blood. Veterinary Immunology and Immunopathology, v. 56, n. 3-4, p. 259-69, 1997.

SORDILLO, L. M. Factors affecting mammary gland immunity and mastitis susceptibility. Livestock Production Science, v. 98, p. 89-99, 2005. 
SORDILLO, L. M.; BABIUK, L. A. Modulation of bovine mammary neutrophil function during the periparturient period following in vitro exposure to recombinant bovine interferon gamma. Veterinary Immunology and Immunopathology, v. 27, n. 4, p. 393-402, 1991.

SORDILLO, L. M.; SHAFER-WEAVER, K.; DEROSA, D. Immunobiology of the Mammary Gland. Journal of Dairy Science, v. 80, p. 1851-1865, 1997.

SORDILLO, L. M.; STREICHER, K. L. Mammary gland immunity and mastitis susceptibility. Journal of Mammary Gland Biology and Neoplasia, v. 7, n. 2, p. 135-146, 2002.

SORENSEN, J. T.; ENEVOLDSEN, C. Effect of dry period length on milk production in subsequent lactation. Journal of Dairy Science, v. 74, p.1277-1283, 1991.

STELWAGEN, K.; CARPENTER, E.; HAIGH, B.; HODGKINSON, A.; WHEELER, T. T. Immune components of bovine colostrum and milk. Journal of Animal Science, v. 87, p. 3-9, 2009. Supplement. 1.

TIZARD, I. R. Imunologia veterinária: uma introdução. 7. ed. São Paulo: Roca, 2008.

TODHUNTER, D.A.; SMITH, K. L.; HOGAN, J. S. Environmental Streptococcal Intramammary Infections of the Bovine Mammary Gland. Journal Dairy Science, v. 78, n. 11, p. 2366-2374, 1995.

VAN DORP, R. T.; MARTIN, S. W.; SHOUKRI, M. M.; NOORDHUIZEN, J. P. T. M.; DEKKERS, J. C. M. An epidemiologic study of disease in 32 registered holstein dairy herds in british columbia. Canadian Journal Veterinary Research, v 63, p. 185-192, 1999.

VAN KAMPEN, C.; MALLARD, B. A. Effects of peripartum stress and health on circulating bovine lymphocyte subsets. Veterinary Immunology and

Immunopathology, v. 59, n. 1-2, p. 79-91, 1997.

VANGROENWEGHE, F.; LAMOTE, I.; BURVENICH, C. Physiology of the periparturient period and its relation to severity of clinical mastitis. Domestic Animal Endocrinology, v. 29, p. 283-293, 2005.

WAAGE, S.; ODEGAARD, S. A.; LUND, A.; BRATTGJERD, S.; ROTHE, T. CaseControl study of risk factors for clinical mastitis in postpartum dairy heifers. Journal of Dairy Science, v. 84, p. 392-399, 2001.

WALLER, K. P. Mammary gland immunology around parturition-Influence of stress, nutrition and genetics. Biology of the Mammary Gland., v. 480, p. 231-245, 2000. 
WEBER, P. S. D.; TOELBOELL, T.; CHANG, L.; TIRRELL, J. D.; SAAMA, P. M.; SMITH, G. W.; BURTON, J. L. Mechanisms of glucocorticoid-induced downregulation of neutrophil L-selectin in cattle: evidence for effects at the geneexpression level and primarily on blood neutrophils. Journal of Leukocyte Biology, v. 75, p. 815-827, 2004.

WILDE, C. J.; ADDEY, C. V. P.; LI, P.; FERNIG, D. G. Programmed cell death in bovine mammary tissue during lactation and involution. Experimental Physiology, v. 82, p. 943-953, 1997.

WINGER, K.; GAY, C. C.; BESSER, T. E. Immunoglobulin G1 transfer into induced mammary secretions: the effect of dexamethasone. Journal of Dairy Science, v. 78, n. 6, p. 1306-1309, 1995.

WOOD, D.; QUIROZ-ROCHA, G. F. Normal hematology of cattle. In: Schalm's Veterinary Hematology. 6 $6^{\mathrm{a}}$ ed. Malden: Wiley Blackwell, 2010.

YU, A. B.; ZHAO, G. Q.; TIAN, S. Q.; HUO, Y. J. Relationship between parity and cellular composition of somatic cells in milk of Chinese Holstein cows. Journal of Animal and Veterinary Advances , v. 10, n. 16, p. 2067-2073, 2011. 
Anexos 


\section{Anexo A}

\section{Reagentes: lavagem e separação das células}

\section{PBS - Concentrado 10X}

$\mathrm{Na}_{2} \mathrm{HPO}_{4} 7 \mathrm{H}_{2} \mathrm{O}$

$26,79 \mathrm{~g}$

$\mathrm{NaH}_{2} \mathrm{PO}_{4} \mathrm{H}_{2} \mathrm{O}$

$4,14 \mathrm{~g}$

$\mathrm{NaCl}$

$82 \mathrm{~g}$

Água Milli Q (q.s.p.) $1000 \mathrm{~mL}$

PBS - Solução de uso (1X)

Diluir a solução concentrada 10x (1:10) em água Milli-Q. Ajustar o pH para 7,2-7,4. 
Anexo B

Reagentes para determinação da viabilidade celular

\section{Reagentes}

Azul de Tripan - Solução de Estoque (0.4\%)

$0.4 \mathrm{~g}$ do Pó comercial $100 \mathrm{~mL}$ PBS

Azul de tripan - Solução de Uso (1:5)

$1 \mathrm{~mL}$ da solução de estoque

$4 \mathrm{~mL}$ de PBS 


\section{Anexo C \\ Marcação das bactérias com lodeto de Propídeo}

\section{Reagentes}

Meio de cultura para bactérias

\section{Meio líquido BHI (Brain Heart Infusion)}

Meio BHI desidratado

$37 \mathrm{~g}$

Água destilada

$1000 \mathrm{~mL}$

Distribuir o líquido em frascos de $15 \mathrm{~mL}$ e esterilizar.

Meio sólido TSA (Tryptic Ágar Difco)

Meio TSA desidratado

$60 \mathrm{~g}$

Água destilada $1500 \mathrm{~mL}$

Autoclavar e distribuir 15 a $20 \mathrm{~mL}$ em placas de Petri estéreis.

\section{Solução para lavagem das bactérias}

\section{HBSS (Hank's Buffered Salt Solution) 1X}

Cloreto de cálcio anidro $(\mathrm{CaCl} 2)$ ou $\mathrm{CaCl}_{2} 2 \mathrm{H}_{2} \mathrm{O}$

140 ou $176 \mathrm{mg}$

Cloreto de magnésio hexaidratado $\left(\mathrm{MgCl}_{2}-6 \mathrm{H}_{2} \mathrm{O}\right)$

$100 \mathrm{mg}$

Sulfato de magnésio heptaidratado $\left(\mathrm{MgSO}_{4}-7 \mathrm{H}_{2} \mathrm{O}\right)$

$100 \mathrm{mg}$

Cloreto de Potássio (KCl)

$400 \mathrm{mg}$

Fosfato de potássio monobásico $\left(\mathrm{KH}_{2} \mathrm{PO}_{4}\right)$

$60 \mathrm{mg}$

Bicarbonato de sódio $\left(\mathrm{NaHCO}_{3}\right)$

$350 \mathrm{mg}$

Cloreto de sódio $(\mathrm{NaCl})$ $8000 \mathrm{mg}$

Fosfato de sódio dibásico anidro $\left(\mathrm{Na}_{2} \mathrm{HPO}_{4}\right)$ $48 \mathrm{mg}$

Água $\mathrm{mQ}$ (q.s.p.) $1000 \mathrm{~mL}$ 


\section{Protocolo de marcação de bactérias com lodeto de Propídeo}

\section{Obtenção das bactérias}

Foram utilizadas bactérias Staphylococcus aureus. e Escherichia coli isoladas a partir do leite de vacas com mastite, cedidas gentilmente pelo Prof. Dr. Nilson Roberti Benites, do Departamento de Medicina Veterinária Preventiva e Saúde Animal (VPS) da Faculdade de Medicina Veterinária e Zootecnia da Universidade de São Paulo.

As bactérias cedidas estavam acondicionadas em meio $\mathrm{BHI}$ sólido e foram transferidas para o meio líquido $(\mathrm{BHI})$, incubadas em estufa a $37^{\circ} \mathrm{C}$ por 18 horas. Após este período, $100 \mu \mathrm{L}$ desta solução foram transferidos para placas de Petri contendo o Ágar TSA, incubadas novamente em estufa bacteriológica por 18 horas. Para a obtenção das bactérias, utilizou-se swab estéril e tubos cônicos contendo $10 \mathrm{~mL}$ de solução salina estéril, que foram centrifugados a 1100x g por 10 minutos. Para a inativação das bactérias, adicionou-se a suspensão bacteriana em banho maria a $60^{\circ} \mathrm{C}$ por 60 minutos. Em seguida, as bactérias foram submetidas novamente à centrifugação, conforme descrito anteriormente, o sobrenadante foi desprezado, o botão de bactérias foi dissolvido com auxílio de Vortex, retornando ao volume inicial pela adição de $10 \mathrm{~mL}$ de solução salina estéril. Esse processo foi repetido $1 \mathrm{x}$, e a suspensão final de bactérias $(10 \mathrm{~mL})$ foi congelada a $-80^{\circ} \mathrm{C}$.

A concentração de bactérias foi ajustada para $24 \times 10^{8} / \mathrm{mL}$ diluindo a suspensão celular concentrada até a escala 08 de Mc Farland. Para tanto, foi necessário diluir $10 \mathrm{~mL}$ da Staphylococcus aureus em $40 \mathrm{~mL}$ de solução salina estéril (50 mL); e $10 \mathrm{~mL}$ de Escherichia coli em $30 \mathrm{~mL}$ de salina (40 mL). 


\section{Marcação das bactérias com lodeto de Propídeo (PI)}

\section{Reagentes}

a) lodeto de Propídeo (PI):

A solução de estoque de $\mathrm{PI}(10 \mathrm{mg} / \mathrm{mL})$ foi diluída em HBSS para ajuste da concentração a $100 \mu \mathrm{g} / \mathrm{mL}$. Para o cálculo do volume de PI da solução estoque a ser adicionado em HBSS para obtenção de $20 \mathrm{~mL}$ de solução a $100 \mu \mathrm{g} / \mathrm{mL}$, necessária para a marcação das bactérias suspensas em $20 \mathrm{~mL}\left(24 \times 10^{8} / \mathrm{mL}\right)$ (proporção 1:1), foi utilizada a seguinte fórmula:
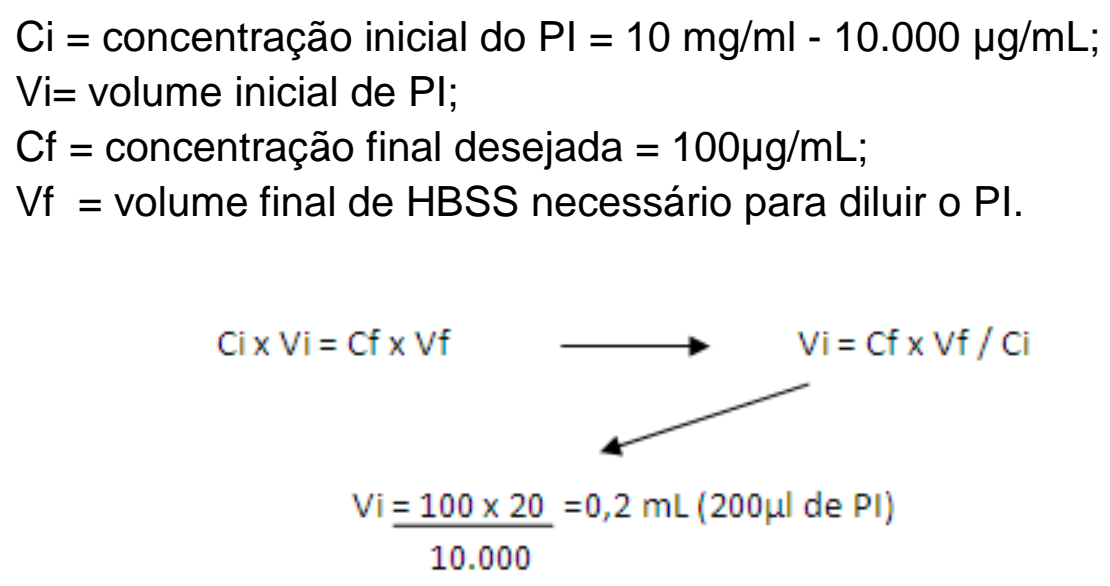

b) Suspensão bacteriana concentração $24 \times 10^{8} / \mathrm{mL}$;

c) Tampão carbonato $0,1 \mathrm{M}$; $\mathrm{pH}$ 9,6 preparado com $80 \mathrm{~mL}$ de $0.2 \mathrm{M} \mathrm{NaCO}, 170 \mathrm{~mL}$ de $0.2 \mathrm{M} \mathrm{NaHCO}_{3}$ e $250 \mathrm{~mL}$ de água destilada;

d) HBSS 1x: preparado no dia do uso $(\mathrm{pH} 7,2$ a 7,4$)$.

\section{Protocolo}

Ao início do processo, o PI foi diluído em tampão carbonato na concentração final de $100 \mu \mathrm{g} / \mathrm{mL}$. O pH do HBSS foi avaliado antes da diluição.

Foram utilizados $10 \mathrm{~mL}$ da solução final das bactérias diluídas em iodeto de propídeo $(100 \mu \mathrm{g} / \mathrm{mL})$ na proporção $1: 1(10 \mathrm{~mL}: 10 \mathrm{~mL})$. A mistura foi mantida a $4^{\circ}$ protegida da luz, sob constante agitação por 24 horas. Após esse período, os frascos foram centrifugados a $16.000 \mathrm{~g}$ por 30 segundos, a $12^{\circ} \mathrm{C}$. Em seguida, as bactérias foram lavadas 2x em HBSS $1 \mathrm{X}(20 \mathrm{~mL})$. A solução final foi aliquotada em 
microtubos de $2 \mathrm{~mL}$, centrifugados a $16.000 \mathrm{~g}$ por 30 segundo a $12^{\circ} \mathrm{C}$. $\mathrm{O}$ sobrenadante foi desprezado e o botão de bactérias foi ressuspendido com $2 \mathrm{~mL}$ de HBSS (1X). Repetiu-se o processo de lavagem bacteriana 1X. Por fim, as bactérias marcadas foram congeladas a $-20^{\circ} \mathrm{C}$, estando prontas para o uso.

Figura 38 - (A) Placa com crescimento da bactéria Staphylococcus aureus; (B) Placa com crescimento da Escherichia coli; (C) Totalidade das bactérias recolhidas das placas - à esquerda $E$. coli e à direta $S$. aureus; (D) Bactérias marcadas com $\mathrm{PI}$; (E) Botão de bactérias marcadas com PI em etapa final de processamento São Paulo, 2013

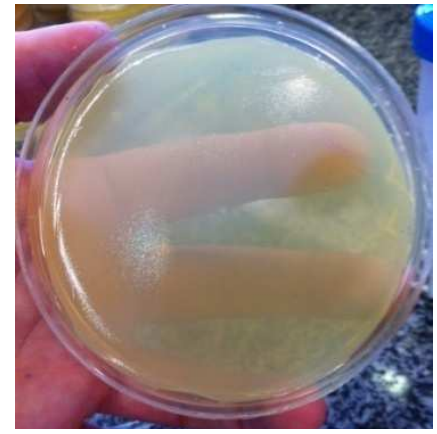

(A)

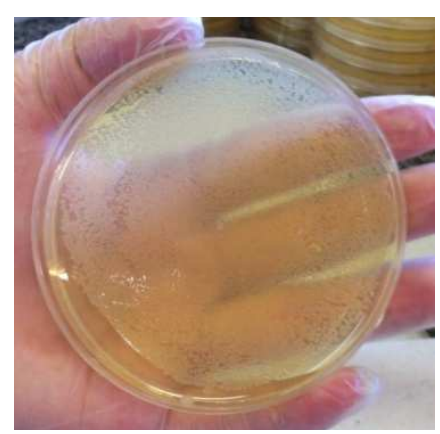

(B)

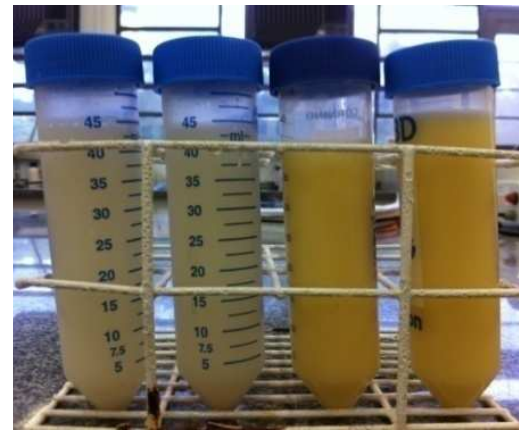

(C)

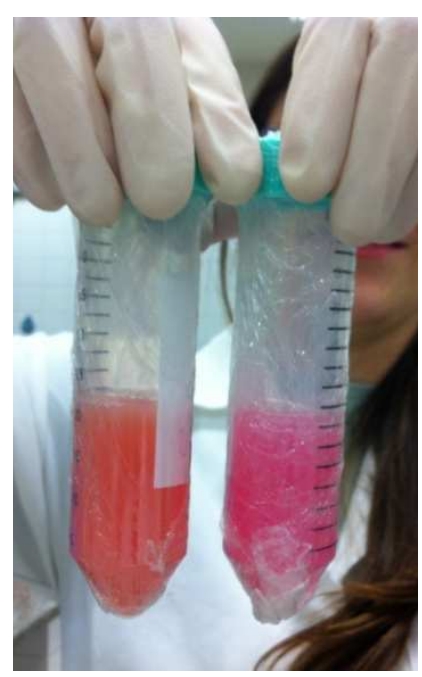

(D)

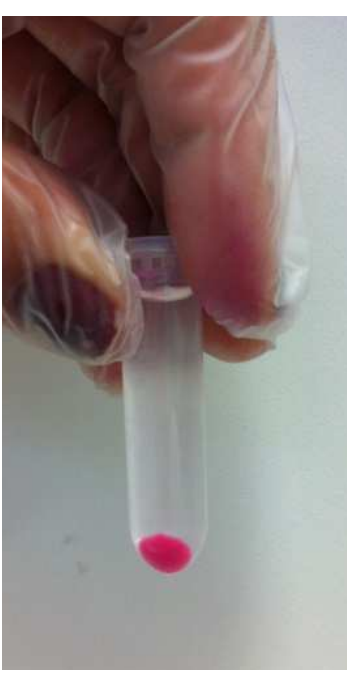

(E) 


\section{Anexo D}

Soluções utilizadas no protocolo de Fagocitose e Produção de $\mathrm{H}_{2} \mathrm{O}_{2}$

DCFH - Solução de estoque - 25 mM

Pó comercial

$24,35 \mathrm{mg}$

Etanol

$2 \mathrm{~mL}$

Proteger da luz - Manter em freezer $-20^{\circ} \mathrm{C}$

DCFH - Solução de uso

Solução de estoque

$100 \mu \mathrm{L}$

PBS

$8,2 \mathrm{~mL}$

Adaptar a quantidade da solução a ser preparada, para a quantidade necessária apenas para o uso imediato, respeitando as mesmas proporções.

\section{EDTA 3 mM}

$\operatorname{EDTA}\left(\mathrm{C}_{10} \mathrm{H}_{14} \mathrm{~N}_{2} \mathrm{O}_{8} \mathrm{Na}_{2} 2 \mathrm{H}_{2} \mathrm{O}-\mathrm{PM} 372,24 \mathrm{~g} / \mathrm{mol}\right) \quad 1,12 \mathrm{~g}$

PBS (1x)

$1000 \mathrm{~mL}$

Manter refrigerado. 
Apêndices 
APÊNDICE A

Quadro 5 - Identificação, ordem e data de parição das fêmeas bovinas Holandesas

\begin{tabular}{|l|l|c|r|}
\hline Identificação & Nome & Ordem de parto & Data Parição \\
\hline 1332 & llana & $2^{\circ}$ & $25 / 10 / 2013$ \\
\hline 1333 & lasmin & $4^{\circ}$ & $25 / 10 / 2013$ \\
\hline 1356 & lara & $2^{\circ}$ & $22 / 10 / 2013$ \\
\hline 1384 & Jangada & $2^{\circ}$ & $23 / 10 / 2013$ \\
\hline 1429 & Lambida & $2^{\circ}$ & $19 / 10 / 2013$ \\
\hline 1433 & Lamparina & $2^{\circ}$ & $26 / 10 / 2013$ \\
\hline 1437 & Laranjeira & $2^{\circ}$ & $21 / 10 / 2013$ \\
\hline 1445 & Libélula & $2^{\circ}$ & $17 / 10 / 2013$ \\
\hline 1447 & Libra & $2^{\circ}$ & $12 / 10 / 2013$ \\
\hline 1453 & Limonada & $2^{\circ}$ & $25 / 10 / 2013$ \\
\hline 4409 & Arlinda & $3^{\circ}$ & $22 / 10 / 2013$ \\
\hline 4410 & Arizona & $4^{\circ}$ & $22 / 10 / 2013$ \\
\hline 1478 & Maisena & $2^{\circ}$ & $23 / 10 / 2013$ \\
\hline
\end{tabular}




\section{APÊNDICE B}

Quadro 6 - Status de higidez do aparelho mamário na semana -4 - São Paulo, 2013

\begin{tabular}{|c|c|c|c|c|c|c|c|c|c|c|c|}
\hline Identificação & VG & VL & Ass. & Col. & Elast. & Temp. & Consist. & Linf. & 1 Bacteriológico & $2^{\circ}$ Bacteriológico & 3ํㅗacteriológico \\
\hline $1445 \mathrm{AD}$ & 1 & 0 & 1 & 0 & 1 & 0 & 1 & 0 & SC & SC & SC \\
\hline 1445 PD & 0 & 0 & 1 & 0 & 0 & 0 & 1 & 0 & SC & SC & SC \\
\hline $1445 \mathrm{AE}$ & 1 & 0 & 1 & 0 & 0 & 0 & 0 & 0 & SC & SC & SC \\
\hline $1445 \mathrm{PE}$ & 0 & 0 & 1 & 0 & 0 & 0 & 1 & 0 & SC & SC & SC \\
\hline $1478 \mathrm{AD}$ & 0 & 0 & 1 & 0 & 0 & 0 & 0 & 0 & SC & SC & SC \\
\hline 1478 PD & 0 & 0 & 1 & 0 & 0 & 0 & 0 & 0 & SC & SC & SC \\
\hline $1478 \mathrm{AE}$ & 0 & 0 & 1 & 0 & 0 & 0 & 0 & 0 & SC & SC & SC \\
\hline $1478 \mathrm{PE}$ & 1 & 3 & 1 & 0 & 0 & 0 & 0 & 0 & SC & SC & $\mathrm{SC}$ \\
\hline $1332 \mathrm{AD}$ & 0 & 0 & 1 & 0 & 0 & 0 & 0 & 0 & SC & SCN & SCN \\
\hline 1332 PD & 2 & 0 & 1 & 0 & 0 & 0 & 1 & 0 & SC & SC & SC \\
\hline $1332 \mathrm{AE}$ & 0 & 0 & 1 & 0 & 0 & 0 & 0 & 0 & SC & SC & SC \\
\hline $1332 \mathrm{PE}$ & 2 & 0 & 1 & 0 & 0 & 0 & 1 & 0 & SC & SC & SC \\
\hline $1429 \mathrm{AD}$ & 0 & 0 & 0 & 0 & 0 & 0 & 0 & 0 & SC & SCN & SCN/SD \\
\hline 1429 PD & 0 & 0 & 0 & 0 & 0 & 0 & 0 & 0 & SCN & SCN & SCN \\
\hline $1429 \mathrm{AE}$ & 0 & 0 & 0 & 0 & 0 & 0 & 0 & 1 & SCN & SCN & SC \\
\hline $1429 \mathrm{PE}$ & 0 & 0 & 0 & 0 & 0 & 0 & 0 & 1 & SC & SC & SC \\
\hline $4410 \mathrm{AD}$ & 0 & 0 & 0 & 0 & 0 & 0 & 0 & 1 & SC & SC & SC \\
\hline 4410 PD & 0 & 0 & 0 & 0 & 0 & 0 & 0 & 0 & SC & SCN & SC \\
\hline $4410 \mathrm{AE}$ & 0 & 0 & 0 & 0 & 0 & 0 & 0 & 1 & SC & SC & SC \\
\hline $4410 \mathrm{PE}$ & 0 & 0 & 0 & 0 & 0 & 0 & 0 & 0 & SC & SC & SCN \\
\hline
\end{tabular}




\begin{tabular}{|c|r|r|r|r|r|r|r|r|r|r|c|}
\hline Identificação & VG & VL & Ass. & Col. & Elast. & Temp. & Consist. & Linf. & 10 Bacteriológico & 20 Bacteriológico & 3 Bacteriológico $^{\circ}$ \\
\hline $4409 \mathrm{AD}$ & 0 & 0 & 0 & 0 & 0 & 0 & 0 & 0 & $\mathrm{SC}$ & $\mathrm{SC}$ & $\mathrm{SC}$ \\
\hline $4409 \mathrm{PD}$ & 0 & 0 & 0 & 0 & 0 & 0 & 0 & 0 & $\mathrm{SCN}$ & $\mathrm{SC}$ & $\mathrm{SCN}$ \\
\hline $4409 \mathrm{AE}$ & 0 & 0 & 0 & 0 & 0 & 0 & 0 & 0 & $\mathrm{SC}$ & $\mathrm{SC}$ & $\mathrm{SC}$ \\
\hline $4409 \mathrm{PE}$ & 0 & 0 & 0 & 0 & 0 & 0 & 0 & 0 & $\mathrm{SC}$ & $\mathrm{SC}$ & $\mathrm{SC}$ \\
\hline $1433 \mathrm{AD}$ & 0 & 0 & 0 & 0 & 0 & 0 & 0 & 0 & $\mathrm{SC}$ & $\mathrm{SC}$ & $\mathrm{SC}$ \\
\hline $1433 \mathrm{PD}$ & 0 & 0 & 0 & 0 & 0 & 0 & 0 & 0 & $\mathrm{SC}$ & $\mathrm{SC}$ & $\mathrm{SC}$ \\
\hline $1433 \mathrm{AE}$ & 0 & 0 & 0 & 0 & 0 & 0 & 0 & 0 & $\mathrm{SC}$ & $\mathrm{SC}$ & $\mathrm{SC}$ \\
\hline $1433 \mathrm{PE}$ & 0 & 0 & 0 & 0 & 0 & 0 & 0 & 0 & $\mathrm{SC}$ & $\mathrm{SC}$ & $\mathrm{SC}$ \\
\hline $1437 \mathrm{AD}$ & 2 & 0 & 1 & 0 & 0 & 0 & 1 & 1 & $\mathrm{SC}$ & $\mathrm{SC}$ & $\mathrm{SC}$ \\
\hline $1437 \mathrm{PD}$ & 0 & 0 & 1 & 0 & 0 & 0 & 0 & 1 & $\mathrm{SC}$ & $\mathrm{SC}$ & $\mathrm{SC}$ \\
\hline $1437 \mathrm{AE}$ & 0 & 0 & 1 & 0 & 0 & 0 & 0 & 1 & $\mathrm{SC}$ & $\mathrm{SC}$ & $\mathrm{SC}$ \\
\hline $1437 \mathrm{PE}$ & 0 & 0 & 1 & 0 & 0 & 0 & 0 & 1 & $\mathrm{SC}$ & $\mathrm{SC}$ & $\mathrm{SC}$ \\
\hline $1333 \mathrm{AD}$ & 0 & 0 & 0 & 0 & 0 & 0 & 0 & 0 & $\mathrm{SC}$ & $\mathrm{SC}$ & $\mathrm{SC}$ \\
\hline $1333 \mathrm{PD}$ & 0 & 0 & 0 & 0 & 0 & 0 & 0 & 0 & $\mathrm{SC}$ & $\mathrm{SC}$ & $\mathrm{SC}$ \\
\hline $1333 \mathrm{AE}$ & 0 & 0 & 0 & 0 & 0 & 0 & 1 & 0 & $\mathrm{SC}$ & $\mathrm{SCN}$ & $\mathrm{SCN}$ \\
\hline $1333 \mathrm{PE}$ & 0 & 0 & 0 & 0 & 0 & 0 & 1 & 0 & $\mathrm{SC}$ & $\mathrm{SC}$ & $\mathrm{SC}$ \\
\hline $1384 \mathrm{AD}$ & 0 & 0 & 0 & 0 & 0 & 0 & 0 & 0 & $\mathrm{SC}$ & $\mathrm{SC}$ & $\mathrm{SC}$ \\
\hline $1384 \mathrm{PD}$ & 0 & 0 & 0 & 0 & 0 & 0 & 1 & 0 & $\mathrm{SCN}$ & $\mathrm{SC}$ & $\mathrm{SCN}$ \\
\hline $1384 \mathrm{AE}$ & 0 & 0 & 0 & 0 & 0 & 0 & 1 & 0 & $\mathrm{SC}$ & $\mathrm{SC}$ & $\mathrm{SC}$ \\
\hline $1384 \mathrm{PE}$ & 0 & 0 & 0 & 0 & 0 & 0 & 0 & 0 & $\mathrm{SC}$ & $\mathrm{SC}$ & $\mathrm{SC}$ \\
\hline $1356 \mathrm{AD}$ & 0 & 0 & 0 & 0 & 0 & 0 & 1 & 0 & $\mathrm{SC}$ & $\mathrm{SC}$ & $\mathrm{SC}$ \\
\hline $1356 \mathrm{PD}$ & 0 & 0 & 0 & 0 & 0 & 0 & 0 & 0 & $\mathrm{SC}$ & $\mathrm{SC}$ & $\mathrm{SC}$ \\
\hline $1356 \mathrm{AE}$ & 0 & 0 & 0 & 0 & 0 & 0 & 0 & 0 & $\mathrm{SC}$ & $\mathrm{SC}$ & $\mathrm{SC}$ \\
\hline $1356 \mathrm{PE}$ & 0 & 0 & 0 & 0 & 0 & 0 & 1 & 0 & $\mathrm{SC}$ & $\mathrm{SC}$ & $\mathrm{SC}$ \\
\hline
\end{tabular}




\begin{tabular}{|c|r|r|r|r|r|r|r|r|r|r|c|}
\hline Identificação & VG & VL & Ass. & Col. & Elast. & Temp. & Consist. & Linf. & 10 Bacteriológico & 20 Bacteriológico & 3ํ Bacteriológico \\
\hline $1447 \mathrm{AD}$ & 0 & 0 & 0 & 0 & 0 & 0 & 1 & 0 & $\mathrm{SC}$ & $\mathrm{SC}$ & $\mathrm{SC}$ \\
\hline $1447 \mathrm{PD}$ & 0 & 0 & 0 & 0 & 0 & 0 & 1 & 0 & $\mathrm{SC}$ & $\mathrm{SC}$ & $\mathrm{SC}$ \\
\hline $1447 \mathrm{AE}$ & 0 & 0 & 0 & 0 & 0 & 0 & 0 & 0 & $\mathrm{SC}$ & $\mathrm{SC}$ & $\mathrm{SC}$ \\
\hline $1447 \mathrm{PE}$ & 1 & 0 & 0 & 0 & 0 & 0 & 0 & 0 & $\mathrm{SC}$ & $\mathrm{SC}$ & $\mathrm{SC}$ \\
\hline $1453 \mathrm{AD}$ & 0 & 0 & 1 & 0 & 0 & 0 & 0 & 0 & $\mathrm{SC}$ & $\mathrm{SC}$ & $\mathrm{SC}$ \\
\hline $1453 \mathrm{PD}$ & 0 & 0 & 1 & 0 & 0 & 0 & 0 & 1 & $\mathrm{SC}$ & $\mathrm{SC}$ & $\mathrm{SC}$ \\
\hline $1453 \mathrm{AE}$ & 0 & 1 & 1 & 0 & 0 & 0 & 1 & 0 & $\mathrm{SC}$ & $\mathrm{SC}$ & $\mathrm{SD}$ \\
\hline $1453 \mathrm{PE}$ & 0 & 1 & 1 & 0 & 0 & 0 & 1 & 1 & $\mathrm{SC}$ & $\mathrm{SC}$ & $\mathrm{SC}$ \\
\hline
\end{tabular}

VG - Volume generalizado : 0 - ausência / 1 - presença; VL - Volume localizado : 0 - ausência / 1 - presença; Ass. - Assimetria : 0 - ausência / 1 - presença; Col. - Coloração: 0 - Normal / 1 - Avermelhada / 2 - Arroxeada; Elast. - Elasticidade: 0 - Normal / 1 Diminuída; Temp. - Temperatura: 0 - Normal / 1 - Aumentada; Consist. - Consistência da Glândula: 0 - Normal / 1 - Endurecida / 2 Edemaciada; Linf. - Linfononodos: 0 - Normais / 1 - Apenas um linfonodo alterado / 2 - Dois linfonodos alterados / SC - Sem crescimento / SCN - Staphylococcus coagulase negativa / SD - Streptococcus dysgalactiae. 